\title{
Peroxy natural products
}

\author{
Dong-Ze Liu, ${ }^{\mathrm{a}, *}$ and Ji-Kai LiU ${ }^{\mathrm{b}, *}$ \\ ${ }^{a}$ Tianjin Institute of Industrial Biotechnology, Chinese Academy of Science, Tianjin 300308, China \\ ${ }^{\mathrm{b}}$ State Key Laboratory of Phytochemistry and Plant Resources in West China, Kunming Institute of Botany, Chinese \\ Academy of Sciences, Kunming 650201, China
}

Received 16 June 2013; Accepted 5 August 2013

(C) The Author(s) 2013. This article is published with open access at Springerlink.com

This review covers the structures and biological activities of peroxy natural products from a wide variety of terrestrial fungi, higher plants, and marine organisms. Syntheses that confirm or revise structures or stereochemistries have also been included, and 406 references are cited.

\section{Introduction}

2 Marine Metabolites

2.1 1,2-Dioxane Carboxylates

2.2 1,2-Dioxolane Carboxylates

2.3 Fatty Acid Derived Peroxy Ketals

2.4 Diterpenes

2.5 Other Marine Metabolites

3 Terrestrial Sources

3.1 Monoterpenes

3.2 Sesquiterpenes

3.2.1 Guaianes

3.2.2 Eudesmanes

3.2.3 Bisabolanes and Germacranes

3.2.4 Sesquiterpene Dimers

3.2.5 Other Sesquiterpenes

3.3 Diterpenes

3.4 Triterpenes

3.5 Others

\section{Steroidal Peroxides}

5 Fatty Acid Metabolites

6 Conclusions

7 Acknowledgements

\section{Introduction}

This review, which is of the literature from 1998 to 2013 , follows the pattern of its predecessors and is devoted to the new occurrence of peroxy compounds ${ }^{1,2}$ and described 639

*To whom correspondence should be addressed. E-mail: liu_dz@tib.cas.cn (D.Z.Liu); jkliu@mail.kib.ac.cn (J.K. Liu) naturally occurring peroxides from 406 articles. In the past more than 10 years, peroxy compounds have been isolated from a wide variety of terrestrial fungi, higher plants, and marine organisms, especially sponge species, many of which exhibited diverse biological properties such as antiinflammatory, antimalarial, antimicrobial, cytotoxic, antitumor activities, and so on.

As a result of the potential for new drug discovery, peroxy compounds have attracted the attention of biologists and chemists throughout the world. So far, some reviews have dealt with the class of natural peroxides: "Peroxy natural products", 1,2 "Natural peroxy anticancer agents", 3 "Bioactive peroxides as potential therapeutic agents", ${ }^{4}$ and "Naturally occurring peroxides with biological activities". 5 Other general reviews are: "Monoterpenoids", "Sesquiterpenoids", "Diterpenoids", "Sesterterpenoids", "Triterpenoids", and "Marine natural products" all published in the journal Natural Product Reports covering from 1998 to 2011. References to other reviews are appropriately placed in the following sections.

In this review, we showed the structures of new peroxides, and previously-reported ones where there has been a structural revision or a newly-established stereochemistry. Previouslyreported peroxides for which first syntheses or new bioactivities are described are referenced, but separate structures are generally not shown. Relevant data published in MEDLINE, Google Scholar, and SciFinder since 1998 have been gathered to formulate the following review.

\section{Marine Metabolites}

2.1 1,2-Dioxane Carboxylates: Marine sponges, notably those from the genera Plakortis and Plakinastrella, continued to provide a source for six-membered ring cyclic peroxides that incorporate a lactone ring. Plakortolides $\mathrm{K}-\mathrm{S}(\mathbf{1}-\mathbf{9})^{7}$ were isolated from the Australian sponge Plakinastrella clathrata. Detailed configurational investigation also revealed that the structure for previously reported plakortolide $E^{6}$ should be 
revised to a non-peroxidic metabolite and the commonly assumed biosynthesis of the cyclic peroxide via Diels-Alder addition of singlet oxygen is incorrect. ${ }^{7}$ The first total synthesis of seco-plakortolide E also supported the structural revision of plakortolide E. ${ }^{8}$

Continuing investigation of the same sponge, $P$. clathrata, afforded an additional set of 16 plakortolide metabolites 10-25. ${ }^{9}$ A Jamaican collection of Plakinastrella onkodes yielded two cyclic peroxides, plakortolide F 26 and plakortolide $\mathrm{G}$ 27. The absolute stereochemistry of plakortolide $\mathrm{G}$ was proposed from a combination of optical rotation and molecular modelling data. Plakortolide $\mathrm{G}$ exhibited potent inhibitory activity against the AIDS opportunistic parasitic infection Toxoplasma gondii. ${ }^{10}$ The trivial name plakortolide $\mathrm{F}$ was also given to a different peroxide $\mathbf{2 8}$, which was obtained from an unidentified species of Plakinastrella collected in the Seychelles. ${ }^{11}$ Two 1,2-dioxane peroxylactones, plakortolides H and I 29 and 30, have been isolated from a Madagascar specimen of Plakortis aff simplex, both of which were cytotoxic against a range of human tumour cell lines. ${ }^{12}$ Several years later, the relative and absolute configurations of plakortolide I were revised on the basis of synthetic studies and reassignment of the NMR data, ${ }^{8,13}$ thereby establishing that the metabolite isolated was ent-plakortolide I 31. Whilst the trivial name plakortolide I has been proposed for an unnamed plakortolide metabolite $\mathbf{3 2}$ from the Philippine Sponge Plakinastrella sp., whose absolute stereochemistry was determined by application of Mosher's method to a derivative. ${ }^{14}$ The authors also detail the unreliability of specific rotation measurements in the determination of absolute

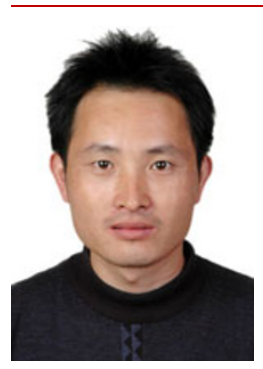

Dong-Ze Liu was born in Shandong province, China, in 1976. He received his B.Sc. (2001) and M.Sc. (2004) degrees from Qingdao Agricultural University and Shanghai Jiao Tong University, respectively. In 2007, he completed his Ph.D. degree in Phytochemistry from Kunming Institute of Botany, Chinese Academy of Sciences (CAS). From 2008 to 2010 he worked as a postdoctoral fellow at the South China Sea Institute of Oceanology, CAS, in Marine Natural Products. In 2011, he joined the Tianjin Institute of Industrial Biotechnology, CAS. His current research interests are focused on the isolation, structure determination, and structural modification of natural products.

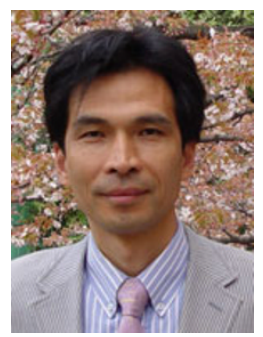

Ji-Kai Liu is a professor of Kunming Institute of Botany since 1997. He acquired his Ph.D. degree at Lanzhou University in 1988. From 1993 to 1994 he worked as a research fellow of Alexander von Humboldt at the University of the Saarland in Germany. Then he worked as a research scientist at the Pharma Research Center of Bayer AG in Germany. His field of interest concerns natural bioactive compounds from higher fungi. He has published over 200 peer-reviewed articles in international journals including Chem. Rev., Angew. Chem. Int. Ed., Nat. Prod. Rep., and Org. Lett. etc. He is the author of the book Mycochemistry and also one of the inventers for ten patents. He is the main founder of BioBioPha Co. Ltd. and the open access journal Nat. Prod. \& Bioprospect..
$R$<smiles>[R]c1ccc(CCCCCCCCCCCC[C@H]2C[C@H]3OC(=O)C[C@@H]3OO2)cc1</smiles>

$\mathrm{R}$ $2 \mathrm{R}=\mathrm{OH}$<smiles>[R]c1ccc(CCCCCCCCCCC[C@@H]2C[C@@]3(C)OC(=O)C[C@H]3OO[C@H]2C)cc1</smiles><smiles>C[C@]1(CCCCCCCC/C=C/C=C/c2ccccc2)C[C@H]2OC(=O)C[C@H]2OO1</smiles><smiles>C[C@]1(CCCCCCCC/C=C/C=C/c2ccccc2)C[C@]2(C)OC(=O)C[C@@H]2OO1</smiles><smiles>C[C@]1(CCCCCC/C=C/C=C/c2ccccc2)C[C@]2(C)OC(=O)C[C@H]2OO1</smiles><smiles>C[C@]1(CCCCCC/C=C/C=C/c2ccccc2)C[C@]2(C)OC(=O)C[C@H]2OO1</smiles>

configuration within the plakortolide class of metabolites in the same paper. ${ }^{13}$ The first total synthesis of $\mathbf{3 2}$ has been achieved using a $[2+4]$ photocycloaddition of a singlet oxygen to a diene and iodolactonization as key steps. ${ }^{15} \mathrm{~A}$ different species of Plakortis, P. halichondrioides, yielded additional peroxide-lactone named plakortolide $\mathbf{J} \mathbf{3 3}$, the absolute stereostructure of which was determined by degradation reactions followed by application of Kishi's method for the assignment of absolute configuration of alcohols. ${ }^{16}$ Synthetic efforts in construction the 1,2-dioxane ring of plakortolides have been described. ${ }^{17,18}$

A further cyclic peroxide 34, with a terminal phenyl group but lacking the lactone, was isolated from P. Clathrata. ${ }^{9}$ The ester represents further structural variation within the growing family of cyclic peroxy sponge metabolites.

The stolonoxides and stolonic acids are a family of natural aliphatic endoperoxides obtained from the samples of marine ascidians belonging to the genus Stolonica. Stolonoxide A 35, the first member of the series, was isolated as its methyl ester from the marine tunicate Stolonica socialis. ${ }^{19}$ A further investigation conducted on the same species yielded stolonoxides B-D 36-38, with strong cytotoxic activity against a panel of five tumor cell lines. ${ }^{20}$ The methyl ester derivatives of stolonoxides $\mathrm{A}$ and $\mathrm{C}$ have been identified as potent inhibitors of the mitochondrial respiratory. ${ }^{21}$ In addition, two new members of this structural class possessing a longer aliphatic chain, stolonic acids A and B 39 and 40, were isolated from an Indian Ocean Ascidian Stolonica species. Both compounds exhibited antiproliferative activity against selected human melanoma and ovarian tumor cell lines, with $\mathrm{IC}_{50}$

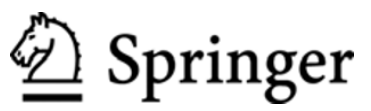


<smiles>CCCCCCCCCCCCCCC[C@]1(C)C[C@H]2OC(=O)C[C@@H]2OO[C@@H]2CC(=O)O[C@@]2(C)C1</smiles><smiles>C[C@]12C[C@](C)(OO1)[C@H]1CC(=O)O[C@@]1(C)C2</smiles><smiles>CCC/C=C/C1C=CC(CCCCCCCC[C@@H]2C[C@@]3(C)OC(=O)C[C@H]3OO2)OO1</smiles><smiles>CCCC=CC1C=CC(CCCCCCCC[C@]2(C)C[C@]3(C)OC(=O)C[C@H]3OO2)OO1</smiles><smiles>CCCC1C=CC(/C=C/CCCCCCCC[C@H]2C[C@]3(C)OC(=O)C[C@H]3OO2)OO1</smiles><smiles>C[C@]1(CCCCCCCCC(=O)O)C[C@H]2OC(=O)C[C@H]2OO1</smiles><smiles>C[C@]1(CCCCCCCCC(=O)O)C[C@]2(C)OC(=O)C[C@H]2OO1</smiles><smiles>C[C@]1(CCCCCCCCC=O)C[C@]2(C)OC(=O)C[C@H]2OO1</smiles>

values of approximately $0.05-0.1 \mu \mathrm{g} / \mathrm{mL}{ }^{22}$ Two new members of the stolonoxide family, stolonoxides $\mathrm{E}$ and F $\mathbf{4 1}$ and $\mathbf{4 2}$, were obtained from samples of the marine ascidian $S$. socialis. Both compounds displayed low micromolar cytotoxicity against a panel of human tumor cell lines. ${ }^{23}$

The marine sponges of the genus Plakortis are also prolific producers of cyclic polyketide peroxides and structurally related compounds that exhibit a broad spectrum of biological properties. The bioactive cyclic peroxide plakortide Q $\mathbf{4 3}$ has been isolated from marine sponge $P$. zyggompha, together with six cyclic peroxide analogues 44-49 in their methyl ester forms. The relative stereochemistry of the 1,2-dioxane ring was established after interpretation of the coupling constant<smiles>C[C@]1(CCCCCCCCCC/C=C/c2ccccc2)C[C@@]2(C)[C@@](C)(CC(=O)O[C@]2(C)CCCCCCCCCC2C=CC(c3ccccc3)OO2)OO1</smiles><smiles>CCC/C=C/C=C/CCCCCCCC[C@]1(C)C[C@]2(C)OC(=O)C[C@H]2OO1</smiles><smiles>C[C@]1(CCCCCCCCC=O)C[C@]2(C)OC(=O)C[C@@H]2OO1</smiles><smiles>C[C@]1(CCCCCCCCO)C[C@]2(C)OC(=O)C[C@H]2OO1</smiles><smiles>C[C@]1(CCCCCCCCO)C[C@]2(C)OC(=O)C[C@@H]2OO1</smiles><smiles>O=C1C[C@H]2OO[C@H](CCCCCCCCO)C[C@H]2O1</smiles><smiles>C[C@@]12C[C@@](C)(OO1)[C@H](CCCCCCCCO)CC(=O)O2</smiles><smiles>C/C(=C\Cc1ccccc1)CCC[C@H](C)C[C@]1(C)C[C@H]2OC(=O)C[C@]2(O)OO1</smiles>

values and the NOESY data. ${ }^{24}$ Interestingly, a sample of the crude extract of the sponge left standing in methanol for one year yielded the methyl esters directly; this finding may go some way to accounting for the prevalence of methyl esters as reported metabolites of Plakortis species. The name plakortide Q was also proposed for a different peroxide 50, which was isolated from the Caribbean sponge $P$. Simplex. ${ }^{25}$ In the same paper, the complete spectroscopic and stereostructural assignments of known 3-epi-plakortin has been reported. Three further cyclic peroxides, dihydroplakortin 51, plakortides I $\mathbf{5 2}$ and J 53, were obtained from the same source, $P$. Simplex, by the same group, as well as providing the

\section{照 Springer}


<smiles>C/C(=C\Cc1ccccc1)CCC[C@H](C)C[C@]1(C)C[C@]2(C)OC(=O)C[C@H]2OO1</smiles>

27<smiles>C[C@]1(CCCCCCCCCc2ccc(O)cc2)C[C@]2(C)OC(=O)C[C@H]2OO1</smiles><smiles>C/C(=C\C=C\CCC/C=C/c1ccccc1)C[C@]1(C)C[C@]2(C)OC(=O)C[C@H]2OO1</smiles><smiles>C[C@]1(CCCCCCCCCCc2ccccc2)C[C@]2(C)OC(=O)C[C@H]2OO1</smiles><smiles>C[C@]1(CCCCCCCCCCc2ccccc2)C[C@]2(C)OC(=O)C[C@H]2OO1</smiles><smiles>C[C@]1(CCCCCCCCCCc2ccccc2)C[C@]2(C)OC(=O)C[C@H]2OO1</smiles>

absolute stereochemistries of known plakortin and plakortide $\mathrm{H}^{26,27}$ The first synthesis of dihydroplakortin $\mathbf{5 1}$ has been achieved, featuring a one-pot three-step hydroperoxysilylation/ cyclization reaction for the construction of the endoperoxide ring system. ${ }^{28}$ An insight into the mechanism of the<smiles>C=CCC/C=C\C=C/CCCC[C@H]1CC[C@H]([C@H]2CCC(CC(=O)O)OO2)O1</smiles><smiles>CCCC/C=C\C=C/CCC[C@H]1CC[C@H]([C@H]2CCC(CC(=O)O)OO2)O1</smiles><smiles>O=C(O)C[C@H]1CC[C@H]([C@H]2CC[C@@H](CCCCCCC3/C=C\C=C/C=C\C3)O2)OO1</smiles><smiles>O=C(O)C[C@H]1CC[C@H]([C@H]2CC[C@H](CCCCCCC3/C=C\C=C/C=C\C3)O2)OO1</smiles><smiles></smiles><smiles>C=C1C[C@](C)(CCCCCCCC/C=C/C=C/c2ccccc2)OO[C@H]1CC(=O)OC</smiles><smiles>C=CCC/C=C/C=C/CCCCCC[C@H]1CC[C@H]([C@H]2CC[C@@H](CC(=O)O)OO2)O1</smiles>

35<smiles>C=CCC/C=C/C=C/CCCCCC[C@@H]1CC[C@H]([C@H]2CC[C@@H](CC(=O)O)OO2)O1</smiles>

36<smiles>C=CCC/C=C/C=C/CCCCCC[C@H]1CC[C@H]([C@H]2CC[C@@H](CC(=O)O)OO2)O1</smiles>

37<smiles>C=CCC/C=C/C=C/CCCCCC[C@H]1CC[C@H]([C@H]2CC[C@@H](CC(=O)O)OO2)O1</smiles>

38

antimalarial action of plakortin and dihydroplakortin, simple 1,2-dioxanes isolated from the sponge P. Simplex, has been reported. $^{29}$

The Australian marine sponge Plakortis sp. yielded two plakortide Q derivatives 54 and 55. Both were potent (nM) inhibitors of Trypanosoma brucei. ${ }^{30}$ Six cyclic peroxides 56-61 were isolated from an Okinawan Plakortis sp. and one of these, the peroxide 61, was shown to be cytotoxic. ${ }^{31,32}$ The antileishmanial peroxides 62 and $\mathbf{6 3}$ were reported from $P$. aff. angulospiculatus collected from Palau together with peroxide 64, which were inactive. ${ }^{33}$ Peroxides 56 and 64 have the same gross structure but the difference in optical rotations suggests that they have different stereochemistries. Fractionation of the sponge Plakortis sp. collected around the Amirantes Islands provided peroxides 63,65 and $66 .{ }^{34}$ The relative and absolute stereochemistry of the cyclic peroxide 67 , originally isolated from $P$. angulospiculatus, ${ }^{35}$ has been proposed by comparison to the optical rotation and NMR spectral data of synthesized diastereomers. ${ }^{36}$

Two independent collections of an undescribed sponge Plakortis sp. from Discovery Bay, Jamaica, yielded four cyclic peroxides plakortides I-L 68-71, and two related compounds 72 and 73, respectively. ${ }^{37,38}$ Plakortide I represents the first report of a polyketide-derived cyclic peroxide with an $\alpha, \beta$ unsaturated ketone moiety in the side chain and exhibits significant antimalarial activity against the W2 Clone of Plasmodium falciparum with an $\mathrm{IC}_{50}$ value of $570 \mathrm{ng} / \mathrm{mL}$, whilst both $\mathbf{7 2}$ and $\mathbf{7 3}$ exhibited significant antimicrobial 
<smiles>CCCCC(CC)CC(C)C[C@]1(CC)C[C@H](CC)[C@@H](CC(=O)O)OO1</smiles>

43<smiles>C/C=C/C(CC)CC(C)C[C@]1(CC)C[C@H](CC)[C@@H](CC(=O)O)OO1</smiles>

46<smiles>CCCC(CC)CC(C)C[C@]1(CC)C[C@H](CC)[C@@H](CC(=O)O)OO1</smiles>

49<smiles>CCCCC(CC)C/C=C/[C@@]1(CC)C[C@H](CC)[C@@H](CC(=O)O)OO1</smiles>

52<smiles>CCC(CC(C)C[C@]1(CC)C[C@H](CC)[C@@H](CC(=O)O)OO1)C(=O)O</smiles>

55<smiles>CC/C=C/C(CC)C/C(=C/[C@@]1(CC)C[C@H](CC)[C@@H](CC(=O)O)OO1)CC</smiles>

58<smiles>CCCC(CC)CC(C)C[C@]1(CC)C[C@H](CC)[C@@H](CC(=O)O)OO1</smiles>

44<smiles>CC/C=C/C(CC)CC(C)C[C@]1(CC)C[C@H](C)[C@@H](CC(=O)O)OO1</smiles>

47<smiles>CC/C=C/C(CC)C[C@@]1(CC)C[C@H](CC)[C@@H](CC(=O)OC)OO1</smiles>

50<smiles>CC/C=C/C(CC)C/C=C/[C@@]1(CC)C[C@H](CC)[C@@H](CC(=O)O)OO1</smiles>

53<smiles>CC/C=C/[C@H](CC)C/C(=C/[C@@]1(CC)C[C@H](CC)[C@@H](CC(=O)O)OO1)CC</smiles>

56<smiles>CCCC[C@H](CC)C/C(=C/[C@@]1(CC)C[C@H](CC)[C@@H](CC(=O)O)OO1)CC</smiles>

59<smiles>CC/C=C/C(CC)CC(C)C[C@]1(CC)C[C@H](CC)[C@@H](CC(=O)O)OO1</smiles>

45

48<smiles>CCCCC(CC)C[C@@H]1C[C@H](CC)[C@@H](CC(=O)OC)OO1</smiles>

51<smiles>CCC(/C=C/C(C)=O)CC(C)C[C@]1(CC)C[C@H](CC)[C@@H](CC(=O)O)OO1</smiles>

54<smiles>CCCC[C@H](CC)C/C(=C/[C@@]1(CC)C[C@H](CC)[C@@H](CC(=O)O)OO1)CC</smiles>

57<smiles>CC/C=C/[C@H](CC)C/C(C)=C/[C@@]1(CC)C[C@H](CC)[C@@H](CC(=O)O)OO1</smiles>

60

activity against pathogenic bacteria and fungi with $\mathrm{IC}_{50}$ values of $0.9-5.0 \mu \mathrm{g} / \mathrm{mL}$ and $0.7-8.0 \mu \mathrm{g} / \mathrm{mL}$, respectively. The plakortides named I and $\mathrm{J}$ have been renamed plakortides $\mathrm{M}$ and $\mathrm{N}$ as the trivial names had been used previously for related metabolites isolated from $P$. Simplex. ${ }^{27}$ Unfortunately, the trivial names plakortides $\mathrm{M}$ and $\mathrm{N}$ were also proposed for another two compounds $\mathbf{7 4}$ and $\mathbf{7 5}$ from the Caribbean marine sponge $P$. Halichondrioides, which exhibited potent cytotoxicity to an array of human tumour cell lines. ${ }^{39}$ A Japanese specimen of Monotria japonica yielded the monotriajaponides B-D 76-78, which can lyse starfish oocytes without disruption of nuclear structure. ${ }^{40}$ Interestingly, the absolute stereochemistries of $\mathbf{7 6 - 7 8}$, as determined by reduction and a modified Mosher method, were opposite to those determined for the plakortides $\mathbf{7 4}$ and $\mathbf{7 5}$. Investigation of the bioactive crude extract from the sponge $P$. angulospiculatus from Brazil led to the isolation of the cyclic peroxide plakortenone $79 .{ }^{41}$ A sample of the Norwegian sponge $P$. simplex was found to contain two cyclic peroxides $\mathbf{8 0}$ and $\mathbf{8 1}$, of which $\mathbf{8 1}$ exhibited moderate in vitro activity against several solid human tumor cell lines with $\mathrm{IC}_{50}$ values in the range $7-15 \mu \mathrm{g} / \mathrm{mL}^{42}$ An Indonesian sponge $P$. nigra was the source of two isomeric cytotoxic trans epoxides, plakorstatins $1(\mathbf{8 2})$ and $2(\mathbf{8 3}){ }^{43}$

Three cytotoxic cyclic peroxides, ethyl plakortide Z 84, ethyl didehydroplakortide $Z \mathbf{8 5}$, which demonstrated selective activity in vitro against solid tumors but lacked activity in vivo, and methyl didehydroplakortide $\mathrm{Z} \mathbf{8 6}$ were isolated from $P$. lita collected from Papua New Guinea. ${ }^{44}$ An Okinawan specimen of the same species provided two futher cytotoxic endoperoxides, haterumadioxins $\mathrm{A}$ and B 87 and 88 with moderate cytotoxicity ${ }^{45}$ Plakortide $\mathrm{F}$, originally isolated from $P$. Halichondrioides, ${ }^{46}$ interfered with $\mathrm{Ca}^{2+}$ homeostasis to mediate the antifungal activity. ${ }^{47}$ 
<smiles>CC/C=C/[C@H](CC)CC(C)C[C@]1(CC)C[C@H](CC)[C@@H](CC(=O)O)OO1</smiles>

61<smiles>CC/C=C/C(CC)C/C(=C/C1(CC)C[C@H](CC)[C@@H](CC(=O)O)OO1)CC</smiles>

64

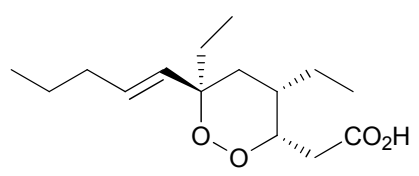

68<smiles>CCC/C=C/[C@]1(CC)C[C@H](CC)[C@@H](CC(=O)OC)OO1</smiles>

71<smiles>CC/C=C/C(CC)C/C=C/[C@@]1(CC)C[C@H](CC)[C@@H](CC(=O)O)OO1</smiles>

74<smiles>CCC(/C=C/C(C)=O)C[C@]1(C)CC(CC)[C@@H](CC(C)=O)OO1</smiles><smiles>CC/C(=C\[C@@]1(CC)C[C@H](CC)[C@@H](CC(=O)OC)OO1)[C@@H]1O[C@@H]1CC</smiles>
$839 R, 10 R$ or $9 S, 10 S$<smiles>CC/C=C/C(CC)CC1(CC)C=C(CC)[C@@H](CC(=O)O)OO1</smiles>

87<smiles>[R]OC(=O)C[C@H]1OO[C@](CC)(C[C@@H](C)CCCC)C=C1CC</smiles>

$62 \mathrm{R}=\mathrm{H}$

$63 \mathrm{R}=\mathrm{CH}_{3}$ $65 \mathrm{R}=\mathrm{C}_{2} \mathrm{H}_{5}$<smiles>CCCC(C)CC(CC)CC[C@]1(CC)C[C@H](CC)[C@@H](CC(=O)O)OO1</smiles>

66<smiles>CCC(=O)/C=C/[C@@]1(CC)C[C@H](CC)[C@@H](CC(=O)OC(C)=O)OO1</smiles>

69

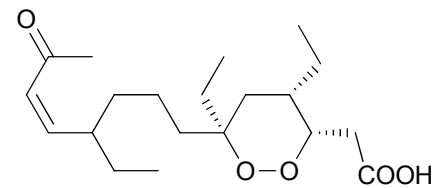

72<smiles>CC/C=C/C(CC)C/C(=C/[C@@]1(CC)C[C@H](CC)[C@@H](CC(=O)O)OO1)CC</smiles>

75<smiles>CCCCC[C@]1(CC)C=C(CC)C(CC(=O)OC)OO1</smiles><smiles>CCCC[C@]1(CC)C[C@H](CC)[C@@H](CC(=O)OCC)OO1</smiles>

84<smiles>CCCCC(CC)CC1(CC)C=C(CC)[C@@H](CC(=O)O)OO1</smiles>

88<smiles>CC/C=C/C(CC)C[C@@H](C)C[C@]1(CC)C=C(CC)C(CC(=O)O)OO1</smiles><smiles>CC[C@H]1C[C@](/C=C/CC(C)C)(CC)OO[C@H]1CC(C)=O</smiles>

70

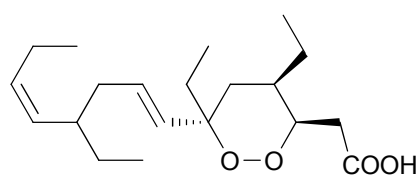

73<smiles>[R2]/C(=C\[C@@]1(CC)C[C@H](CC)[C@@H](CC(=O)O)OO1)CC([R7])CCCC</smiles>

$76 \mathrm{R}_{1}=\mathrm{CH}_{3}, \mathrm{R}_{2}=\mathrm{H}$

$77 \mathrm{R}_{1}=\mathrm{CH}_{3} \quad \mathrm{R}_{2}=\mathrm{CH}_{3}$

$78 \mathrm{R}_{1}=\mathrm{Et}, \mathrm{R}_{2}=\mathrm{CH}_{3}$<smiles>CCCCCC[C@]1(CC)C=C(CC)C(CC(=O)OC)OO1</smiles><smiles>[R]OC(=O)C[C@H]1OO[C@](/C=C/CC)(CC)C[C@@H]1CC</smiles>

$85 \mathrm{R}=\mathrm{CH}_{2} \mathrm{CH}_{3}$

$86 \mathrm{R}=\mathrm{CH}_{3}$<smiles>CC/C=C/C(CC)C/C=C/[C@@]1(CC)C[C@H](CC)[C@@H](CC(=O)O)OO1</smiles>

89
A Jamaican collection of $P$. Halichondrioides afforded a peroxide acid 89 with moderate antifungal activity. ${ }^{48}$ A twosponge complex comprising $P$. halichondrioides and Xestospongia deweerdtae (Bahamas) yielded one $\omega$-phenyl polyketide peroxide named plakinic acid $\mathrm{K} \mathrm{90.} \mathrm{The} \mathrm{absolute}$ configurations of the isolated chiral centres were determined using liposomal circular dichroism and comparison with synthetic standards. ${ }^{49}$

\section{然 Springer}


<smiles>C[C@@H](CCC[C@@H](C)CCc1ccccc1)C[C@]1(C)C[C@H](C)[C@@H](CC(=O)O)OO1</smiles>

90<smiles>[R]C(=C/Cc1ccccc1)/C=C(\C)C[C@]1(C)C[C@H](C)[C@@H](CC(=O)OC)OO1</smiles>

$91 \mathrm{R}=\mathrm{H}$

$92 \mathrm{R}=\mathrm{Me}$<smiles>[R][C@H](C)CCCCCC/C=C/c1ccccc1</smiles>

93<smiles>CC[C@](C)(O)CC(C)CCCCCCCCc1ccccc1</smiles>

94<smiles>CC[C@](C)(CC(C)CCCCCC/C=C/c1ccccc1)OC</smiles>

95<smiles>CC(CCCCCCCCc1ccccc1)C[C@]1(C)C[C@@H](C)[C@](C)(O)OO1</smiles><smiles>C[C@H]1C[C@@](C)(C[C@H](C)CCc2ccccc2)OO[C@@H]1CC(=O)O</smiles>

97<smiles>COC(=O)[C@H](C)C1CCC(C)(CCC2=C(C)CCCC2(C)C)O1</smiles><smiles>COC(=O)[C@H](C)C1CCC2(C)CC(CCCC(C)CCCC(C)(O)CCC=C(C)C)(OO2)O1</smiles>

99<smiles>COC(=O)[C@H](C)C1CCC(C)(CCC=C(C)CCC=C(C)CCC=C(C)C)OO1</smiles>

100

Fractionation of the $P$. onkodes extract led to the isolation of the cytotoxic cyclic peroxide methyl capucinoate A 91 and the previously reported, but incompletely characterized, aromatic peroxide 92. ${ }^{50}$ Since $P$. onkodes was extracted in $\mathrm{MeOH}$, the methyl esters 91 and 92 may be isolation artifacts. ${ }^{51}$ Four aromatic peroxides 93-96 were isolated from Plakortis sp. (Orote Peninsula, Guam), of which compounds 93 and 96 showed weak activity against Staphylococcus aureus, with MIC values of 128 and $64 \mu \mathrm{g} / \mathrm{mL}$, respectively. ${ }^{52}$ Plakinic acid I 97 was obtained from $P$. Halichondrioides, and the absolute configuration determined from CD curves by degradation and liposomal ordering of naphthamide derivatives. ${ }^{53}$ Methylation of the crude extract of a Sigmosceptrella sp. from Southern Australia with diazomethane produced a mixture of products, from which nuapapuin methyl ester $\mathbf{9 8}$ and sigmosceptrellin D and E methyl esters 99 and $\mathbf{1 0 0}$ were isolated and identified. Their relative stereochemistries were assigned by established empirical rules and absolute stereochemistries by the advanced Mosher procedure. A plausible biosynthetic pathway has also been proposed that rationalizes key transformations in the biosynthesis of known norterpene cyclic peroxides and related norterpene ketones, dienes and sigmosceptrins. ${ }^{54}$

Sponges of the genus Diacarnus are known to produce terpene peroxides and related metabolites. A norsesterterpene acid, named muqubilone 101, was isolated from the Red Sea sponge D. Erythraeanus. It showed in vitro antiviral activity against herpes simplex type 1 (HSV-1). ${ }^{55}$ The same compound 101, named aikupikoxide $A$, was also isolated almost at the same time by the Scheuer group from the lipophilic extract of the Red Sea sponge D. Erythraenus along with three other cytotoxic cyclic norterpene peroxides, aikupikoxides B-D 102-104. ${ }^{56}$ The same source, D. Erythraenus, afforded another three cytotoxic norsesterterpenoid peroxides, tasnemoxides AC 105-107. ${ }^{57}$

Bioassay-guided isolation of D. Levii collected from Papua New Guinea led to the isolation of four norsesterterpene peroxides, diacarnoxides A-D 108-111, with diacarnoxides A and $\mathrm{B}$ displaying cytotoxic properties and increased activity under hypoxic conditions. ${ }^{58}$ Chemical investigation of the sponge $D$. megaspinorhabdosa provided a series of norterpene 
<smiles>CC(=O)CCC[C@H](C)C(=O)CC/C(C)=C/CCC1(C)CC2OOC(C1)[C@H](C)C2=O</smiles><smiles>CC(=O)CCCC(C)(C)C(=O)CCC1(C)CC2OOC1C2C(C)=O</smiles><smiles>C=C(CCCC(C)(C)O)C(=O)CCC1(C)CC2OOC1C2C(C)=O</smiles><smiles>C=C1CCC[C@]2(C)CCC3(CCC(C(C)C(C)=O)OO3)CC12</smiles>

104<smiles>CC1=C(CCC(C)(O)/C=C/CC2(C)CC(CC(=O)O)OO2)C(C)(C)CCC1</smiles>

105<smiles>C=C(CCC1=C(C)CCCC1(C)C)C(O)CCC1(C)CC(C(C)O)OO1</smiles>

106<smiles>C=C(CCCC1(C)CC(OOC(C)C(C)=O)C1)CCC1(O)C(=C)CCCC1(C)C</smiles>

107

derivatives, diacarperoxides A-G 112-118, of which, diacarperoxide D was cytotoxic. ${ }^{59}$ Re-investigation of $D$. megaspinorhabdosa afforded one further norsesterpene cyclic peroxide, diacarperoxide S 119, which exhibited strong cytotoxic and antimicrobial activities. ${ }^{60}$

Examination of D. bismarckensis (Sanaroa, Papua New Guinea) led to the isolation of two peroxiterpenes ent-(-)muqubilone 120 and $(+)$-muqubilone B 121, active against Trypanosoma brucei (African sleeping sickness). ${ }^{61}$ Specimens of $D$. cf. spinopoculum from the Solomon Islands and Papua New Guinea yielded a series of norterpenes including four norsesterterpene peroxides, ent-muqubilin A 122, entepimuqubilin A 123, muqubilin B 124, and epimuqubilin B
125, and two norditerpene peroxides, nuapapuin B 126 and epinuapapuin B 127, all of which were evaluated for cytotoxicity using a soft agar assay system and the NCI's 60 cell-line screening. Overall, the norsesterterpene peroxides were less selective as cytotoxins than norditerpene peroxide analogs. ${ }^{62}$ The norsesterterpenoid peroxide, epi-muqubilin A 122, inhibited nitric oxide (NO) production in lipopolysaccharide (LPS)-activated murine macrophage RAW 264.7 cells, ${ }^{63}$ and suppressed cyclooxygenase-2 via $\mathrm{IKK} / \mathrm{I} \kappa \mathrm{B} / \mathrm{NF}-\kappa \mathrm{B}$ pathways. ${ }^{64,65}$ Esterification of carboxylic acid mixtures from the New Caledonian sponge $D$. levii resulted in the isolation of the benzyl esters of ent-muqubilin A $\mathbf{1 2 2}$ and deoxydiacarnoate B 128 and the methyl ester of diacarnoate B 129, all of which were screened for antimalarial activity. ${ }^{66}$

Examination of the Taiwanese sponge Negombata cortica revealed a series of related peroxide terpenoids negombatoperoxides A-D 130-133. ${ }^{67}$ Three norsesterterpene cyclic peroxides named trunculins G-I 134-136 were isolated as their methyl esters from an Australian Latrunculia sp., whose absolute stereochemistry about the cyclic peroxide terminus was established by application of the Horeau and Mosher procedures. ${ }^{68}$<smiles>C=C1CCCC(C)(C)C1CCC(C)CCCC1(C)CCC([C@H](C)C(=O)OC)OO1</smiles><smiles>CC(=O)[C@H](C)C1CCC(C)(CCCC(C)CCC2=C(C)CCCC2(C)C)OO1</smiles><smiles>CC(=O)[C@H](C)C1CCC(C)(CCC/C(C)=C/CC2C(C)=CCCC2(C)C)OO1</smiles><smiles>C=C1CCCC(C)(C)C1CCC(C)CCCC1(C)CCC([C@@H](C)C(=O)O)OO1</smiles><smiles></smiles><smiles>CC(=O)CCCC(C)(C)C(=O)CCC1(C)CCC2OOC1C2C(C)=O</smiles><smiles>CC(=O)CCCC(C)(C)C(=O)CCC1(C)CCC2OOC1C2C(C)=O</smiles>

114 
Investigation of a southern Australian sponge of the genus Mycale resulted in the isolation of one norsesterterpene mycaperoxide $G$ methyl ester $\mathbf{1 3 7}$, which was obtained after treatment of the crude extract with diazomethane. ${ }^{69}$ The absolute stereochemistry previously assigned to mycaperoxide F methyl ester by application of the Horeau procedure has been revised by application of the Mosher procedure in the same paper. Bioassay-guided isolation of a Thai marine sponge Mycale sp. afforded a cytotoxic norsesterterpene peroxide mycaperoxide $\mathrm{H}$ 138. Its relative and absolute stereochemistries were established by standard methodology, including chemical interconversions. ${ }^{70}$ Synthetic efforts towards mycaperoxide $\mathrm{B}$, originally isolated from a Mycale $\mathrm{sp}$. from Thailand ${ }^{71}$, have been reported using a biomimetic approach. $^{72,73}$

2.2 1,2-Dioxolane Carboxylates: Although the majority of cyclic peroxides contain 1,2-dioxanes, while a growing number possess the more rare 1,2-dioxolane ring system. Bioassay-guided purification of a Plakinastrella species collected in the Seychelles led to the isolation of two moderately antifungal plakinic acid F 139 and epiplakinic acid F 140, containing a conjugated triene on the side chain. ${ }^{11}$ Examination of a Puerto Rican collection of Plakortis halichondrioides resulted in the isolation of two polyketide endoperoxides, epiplakinic acid F methyl ester 141 and epiplakinidioic acid $\mathbf{1 4 2}$ as well as providing the absolute configuration of known epiplakinic acid $\mathrm{F} .{ }^{16}$ The antifungal plakortisinic acid 143 was isolated from a species of Jamaican Plakortis. The absolute configuration was determined by comparison of calculated and experimental optical rotations. ${ }^{74}$

A Madagascar specimen of $P$. aff. simplex yielded one cyclic peroxide, andavadoic acid 144, which was cytotoxic against a range of human tumour cell lines. ${ }^{13}$ Two peroxide acids 145 and 146, isolated from $P$. onkodes collected in Florida, possessed moderate antifungal activity. ${ }^{48}$ The Palauan Sponge $P$. nigra provided two cyclic peroxides designated epiplakinic acids $\mathrm{G}$ and $\mathrm{H} 147$ and 148. Isolated metabolites were found to inhibit the growth of HCT-116 cells. ${ }^{75}$ The first asymmetric synthesis of 1,2-dioxolane-3-acetic acids has been reported, and a further optimized strategy was applied to the synthesis of four stereoisomers of plakinic acid A, ${ }^{76}$ allowing a complete configurational assignment of plakinic acid A.

One $\omega$-phenyl polyketide peroxide, plakinic acid L 149, was isolated from a two-sponge association of $P$. halichondroides and $X$. deweerdtae. ${ }^{49}$ Synthesis of four possible diastereomers of plakortide $\mathrm{E}^{78}$ established the absolute configuration of plakortide E as shown. ${ }^{79}$ Plakinic acid J $\mathbf{1 5 0}$ was obtained from $P$. Halichondrioides, and the absolute configuration determined from $\mathrm{CD}$ curves by degradation and liposomal ordering of naphthamide derivatives. ${ }^{53}$ The Philippine sponge Plakinastrella sp. yielded two further cyclic peroxides $\mathbf{1 5 1}$ and $\mathbf{1 5 2} .^{12}$

2.3 Fatty Acid Derived Peroxy Ketals: Two acetylenic cycloperoxides named peroxyacarnoic acids C and D (153 and 154) have been isolated as their methyl esters from the Indian sponge Acarnus bicladotylota, ${ }^{80}$ and the structurally related methyl peroxyacarnoates $\mathrm{A}$ and $\mathrm{B} \mathbf{1 5 5}$ and 156, have been found from the Red Sea marine sponge $A$. cf. bergquistae. ${ }^{81}$ The absolute stereochemistries of $\mathbf{1 5 3}-\mathbf{1 5 5}$ were determined

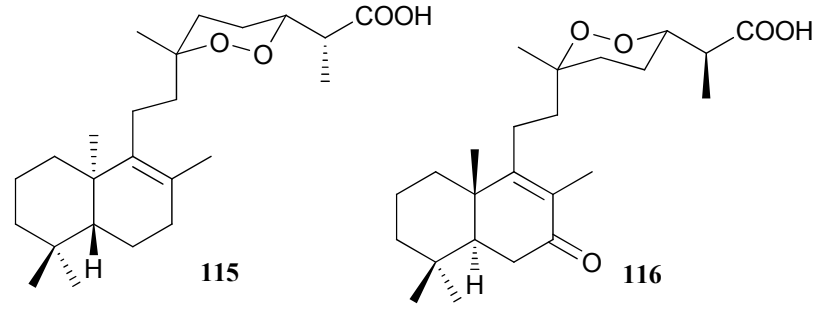

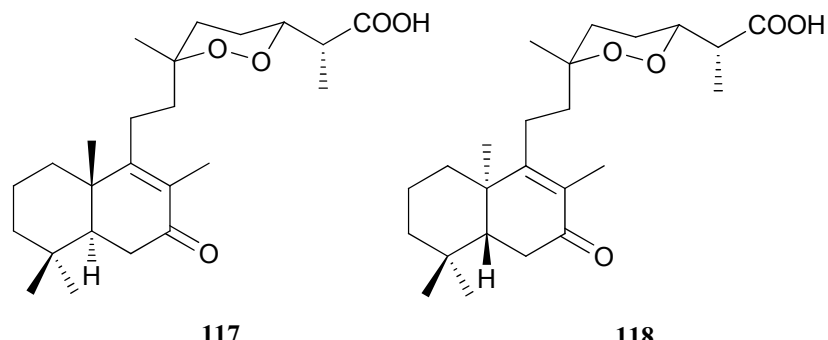<smiles>CC(=O)[C@H](C)[C@H]1CC[C@@](C)(CC[C@@]2(O)[C@H](C)CC[C@]3(C)[C@@H](C)CCC[C@@]32C)OO1</smiles>

by the application of Mosher's method. The syntheses of methyl peroxyacarnoates A and D have been accomplished on the basis of chemoselective ozonolysis within a polyunsaturated framework and Pd-mediated cross-couplings of a functionalized 1,2-dioxane. ${ }^{82}$ The endoperoxyketal polyketides manadoperoxides A-D 157-160 with moderate antimalarial activity were isolated from the Indonesian sponge Plakortis cfr. simplex and their stereostructures were established by means of spectroscopic data and semisynthetic transformations. ${ }^{83}$

Chemical investigation of the marine sponge $P$. cfr. lita afforded a library of endoperoxyketal polyketides named manadoperoxides E-K 161-167 and peroxyplakoric ester C 168, of which manadoperoxides $\mathrm{F} 162, \mathrm{H} \mathrm{164}$, I 165, and $\mathrm{K}$ 167 exhibited remarkable antitrypanosomal activity without cytotoxicity. The report have also demonstrated unambiguously that the endoperoxy group does not confer per se activity against Trypanosoma. ${ }^{84}$ The structures and absolute stereochemistries of known natural products chondrillin ${ }^{85}$ and its C-3 epimer, plakorin ${ }^{86,87}$ have been confirmed by syntheses of $(+)-$ and (-)-chondrillin and $(+)$-and $(-)$-plakorin. ${ }^{88}$

2.4 Diterpenes: One eunicellin-type diterpenoid astrogorgin G 169 has been repored from a Chinese gorgonian Astrogorgia sp., ${ }^{89}$ and the structurally related oxylitophynol $\mathbf{1 7 0}$ and klysimplexin D 171 have been obtained from the soft coral Cladiella krempfi and Klyxum simplex, respectively. ${ }^{90,91}$ From a biogenetical standpoint, oxylitophynol might derive from the formal photo-oxygenation of the corresponding $\Delta^{6,7}$ olefin. Another two substances of this type, briarellin $\mathrm{K}$ hydroperoxide 172 and briarellin D hydroperoxide 173, have been isolated 
<smiles>CC(=O)CCCC(C)(C)C(=O)CC/C(C)=C/CCC1(C)CCC2CC1OO2</smiles>

120<smiles>CC(=O)CCCC(C)(C)C(=O)CC/C(C)=C/CCC1(C)CC2CC1(C)OO2</smiles>

121<smiles>CC(=O)[C@H](C)[C@]1(C)CC[C@@](C)(CC/C=C2\C=C3CCCC(C)(C)C3(O)CC2)OO1</smiles><smiles>C=C1CCCC(C)(C)C1CC[C@]1(C)CC[C@@H]([C@@H](C)C(=O)O)OO1</smiles><smiles>C=C1CCCC(C)(C)C1CC[C@]1(C)CC[C@@H]([C@@H](C)C(C)=O)OO1</smiles>

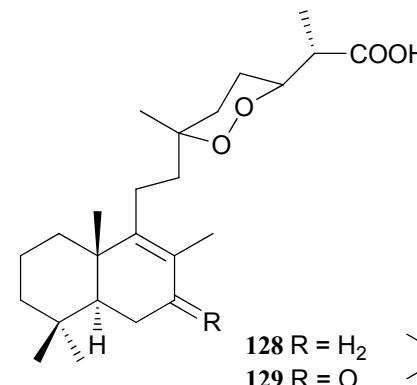<smiles>CCC(C)(CO)CC/C=C(\C)CCC12OC1(C)CCCC2(C)C</smiles><smiles>CC(=O)/C=C/CC1(C)CC2OOC(C1)C2C(=O)O</smiles><smiles>C=C1C2CCC(C)=CC2CC(C)C1(C)CCC(C)(CCC(C)C(=O)O)OOC(C)CCC1(C)CC2OOC(C)(CC=CC3(C)CCC(=O)O3)CC2C1C</smiles><smiles>CC1=CC2CC(C)C3(C)CC(C4(C)CCC([C@@H](C)C(=O)O)OO4)OC3(C)C2CC1</smiles>

136<smiles>CC(=O)C(C)C1CCC(C)(CCC2=C(C)CC[C@]3(C)[C@@H](C)CCC[C@H]23)OO1</smiles>

137<smiles>CC(C(=O)O)C1CCC(C)(CC[C@]2(C)C3C=CC[C@H](C)[C@H]3CC[C@@H]2C)OO1</smiles>

138 from a Puerto Rican collection of Briareum polyanthes, ${ }^{92}$ and this study has also led to a revision of the structure of previously reported briarellin $A^{93}$ to 174 . The structure originally assigned to 11-acetoxy-4-deacetoxyasbestinin $\mathrm{F}^{94}$ has been revised to $\mathbf{1 7 5}^{95}$ Spectroscopic discrepancies observed for the enantioselectively synthesised structure originally proposed for alcyonin ${ }^{96}$ have led to the proposal that the correct structure of the natural product is the allylic peroxide $176 .^{97}$

Two dolabellane diterpenoids 177 and $\mathbf{1 7 8}$ with antiprotozoan activity have been obtained from a Colombian gorgonian coral of the genus Eunicea. ${ }^{98}$ New diterpenoid, 179 having a dolabellane skeleton, was isolated from the Okinawan soft coral of the genus Clavularia. This diterpenoid showed cytotoxic activity against several tumor cell lines. ${ }^{99}$ Other compounds of this type included calyculatine $\mathbf{1 8 0}$ from E. calyculata, and $\left(1 R^{*}, 7 R^{*}\right)$-7-hydroperoxydolabella-

\section{是 Springer}


<smiles>CCC=CC=CC=CC=CC=CC=CCCCCCCCC[C@]1(C)C[C@](C)(CC(=O)O)OO[C@]1(C)CCCCCCCCCCC=CC=CC=CCC</smiles>

143<smiles>C[C@]1(CCCCCCCCCCc2ccccc2)C[C@](C)(CCCCCCC(=O)O)OO1</smiles><smiles>CC(CCCCCC/C=C/C=C/c1ccccc1)CC1(C)C[C@](C)(CC(=O)O)OO1</smiles>

145<smiles>CO[C@@]1(CCCC#C/C=C/CCCCCCCC(C)=O)CC[C@@H](CC(=O)O)OO1</smiles><smiles>CCCCCCCCC/C=C/C#CCCC[C@]1(OC)CC[C@@H](CC(=O)O)OO1</smiles><smiles>C=CCCCCCCC/C=C/C#CCCCC1(OC)CCC(CC(=O)OC)OO1</smiles><smiles>C#CCCCCCCC/C=C/C#CCCCC1(OC)CCC(CC(=O)OC)OO1</smiles>

146<smiles>CC(CCCCCCCCc1ccccc1)CC(C)C[C@]1(C)C[C@@](C)(CC(=O)O)OO1</smiles>
147<smiles>CC(CCCCCCCCc1ccccc1)CC(C)CC1(C)CC(C)(CC(=O)O)OO1</smiles>
148<smiles></smiles>

150<smiles>[R]OC(=O)C[C@]1(C)C[C@](C)(CCCCCC/C=C/C=C/C/C=C\CC)OO1</smiles>

$151 \mathrm{R}=\mathrm{CH}_{3}$

$152 \mathrm{R}=\mathrm{H}$<smiles>[R]C=C(C)C=CCCC[C@]1(O)C[C@H](C)[C@@H](CC(=O)OC)OO1</smiles>

$157 \mathrm{R}=\mathrm{CH}_{3}$

$158 \mathrm{R}=\mathrm{CH}_{2} \mathrm{CH}_{3}$<smiles>COC(=O)C[C@H]1OO[C@@](O)(CCC/C=C/C(C)=O)C[C@H]1C</smiles>

159<smiles>COC(=O)C[C@H]1OOC(C)(CCC[C@H](O)C=C(C)[C@H](C)O)C[C@@H]1C</smiles>

160 4(16),8(17),11(12)-triene-3,13-dione 181 from C. inflata. ${ }^{100,101}$ Compound $\mathbf{1 8 1}$ showed strong cytotoxic activity against several cancer cell lines.

One unusual pyran-ring containing cladiellane diterpene designated tritoniopsin B $\mathbf{1 8 2}$ was isolated from both the nudibranch Tritoniopsis elegans and its soft coral prey Cladiella kremp. ${ }^{102}$ Bioassay-guided fractionation of extracts from a Fijian red alga in the genus Callophycus provided one new compound of the diterpene-benzoate class, bromophycoic acid C 183, which exhibited modest activities against methicillin-resistant Staphylococcus aureus and the human malaria parasite Plasmodium falciparum. ${ }^{103}$ Two xeniaphyllane peroxides gibberosins B and C 184 and 185 were isolated from a Taiwanese soft coral Sinularia gibberosa. ${ }^{104}$ Six further members of this family containing the unusual cyclic peroxyhemiketal moiety, sinugibberosides A-F 186-191, have been reported from the same species, $S$. Gibberosa. $^{105}$ It is conceivable that the biogenesis of these compounds derives from intramolecular cyclisation of a hydroperoxide structurally related to gibberosin B. The Formosan soft coral Xenia umbellata collected in Taiwan, 
China, contained a cytotoxic xenicane diterpenoid xeniolide $\mathrm{G}$ 192. ${ }^{106}$ One meroditerpenoid, stypohydroperoxide 193, was obtained from Stypopodium flabelliforme (Long Island, Papua New Guinea). ${ }^{10}$

One cytotoxic bromoditerpene 194 and the related antibacterial bromoditerpene $2 S$-hydroperoxy-12R-hydroxyisobromosphaerol 195 were successively isolated from the<smiles>CC[C@H](O)/C(C)=C/[C@H](O)CCC[C@]1(O)C[C@H](C)[C@@H](CC(=O)OC)OO1</smiles><smiles>COC(=O)C[C@H]1OO[C@](O)(CCC/C=C/C(C)(OC)C(C)O)C[C@@H]1C</smiles><smiles>COC(=O)C[C@H]1OO[C@](C)(CCC[C@H]2O[C@H]2C(C)=O)C[C@@H]1C</smiles>

163<smiles>CCCC(C=O)CCCCC[C@]1(O)C[C@H](C)[C@@H](CC(=O)OC)OO1</smiles><smiles>CC(=O)C[C@H]1OO[C@@](C)(CCC[C@]2(O)C=C(C)C(C)O2)C[C@@H]1C</smiles>

165<smiles>C=C1[C@H](CC)O[C@](O)(CCC[C@]2(O)C[C@H](C)[C@@H](CC(=O)OC)OO2)[C@H]1Cl</smiles>

166<smiles>CC[C@H]1O[C@H](CCC[C@]2(O)C[C@H](C)[C@@H](CC(=O)OC)OO2)[C@H](Cl)[C@@]1(C)OC</smiles>

167<smiles>CC(=O)/C=C/CCC[C@]1(O)CC[C@@H]([C@@H](C)C(C)=O)OO1</smiles>

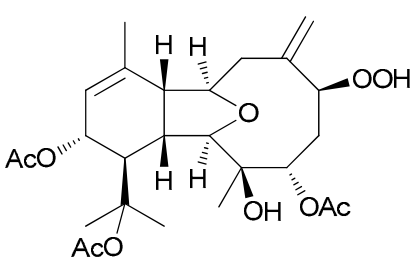

169

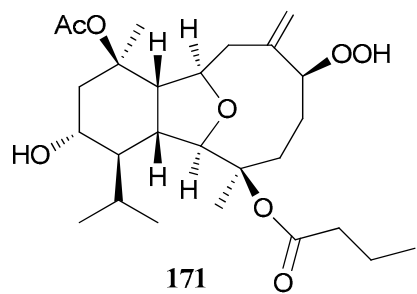

171

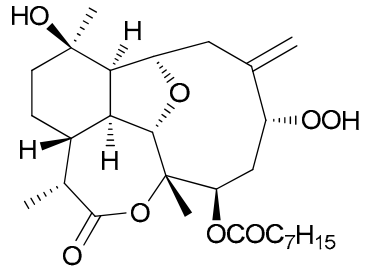

174

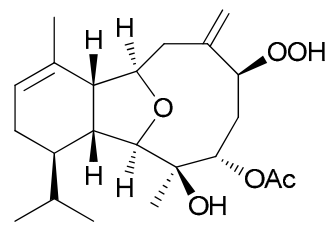

176<smiles>CC(C)=C1C(=O)C[C@]2(C)C/C=C(/C)CC[C@H](O)/C(C)=C/C[C@H]12</smiles>

178<smiles>C=C1CC[C@]2(C)CC(=O)C(=C(C)C)[C@@H]2CC1=O</smiles>

180

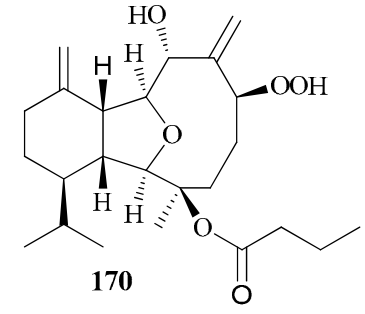

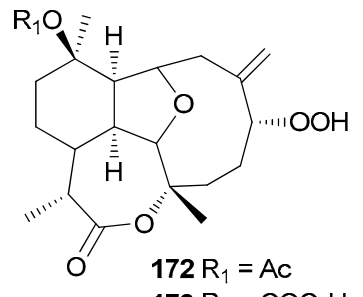
$173 \mathrm{R}_{1}=\mathrm{COC}_{3} \mathrm{H}_{7}$

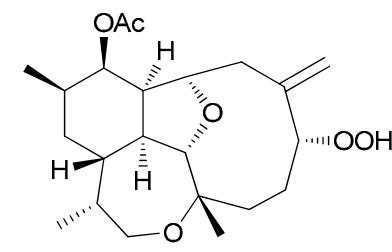

175<smiles>C/C1=C/C[C@]2(C)C(=O)C=C(C(C)C)[C@H]2C/C=C(/C)[C@@H](O)CC1</smiles>

177

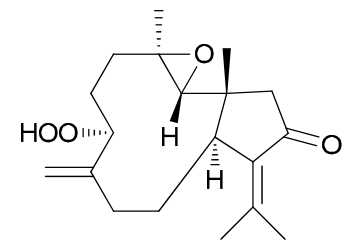

179<smiles>C=C1CCC(O)C(=C)CCC2=C(C(C)C)C(=O)CC2(C)CC1=O</smiles>

181 same collection of Sphaerococcus coronopifolius by the same group. The structure of the previously reported $12 S$-hydroxybromosphaerodiol $^{108}$ and $2 S, 12 S$-dihydroxyisobromosphaerol $^{109}$ were revised to 196 and $\mathbf{1 9 7}$, respectively. The absolute stereochemistry of 194 was established by X-ray crystallographic analyses. ${ }^{110,111}$ 


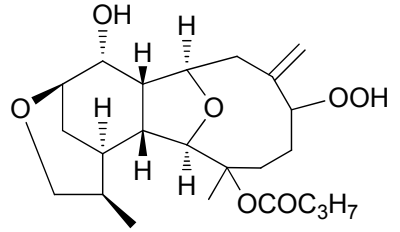

$\mathrm{HOOC}$

182
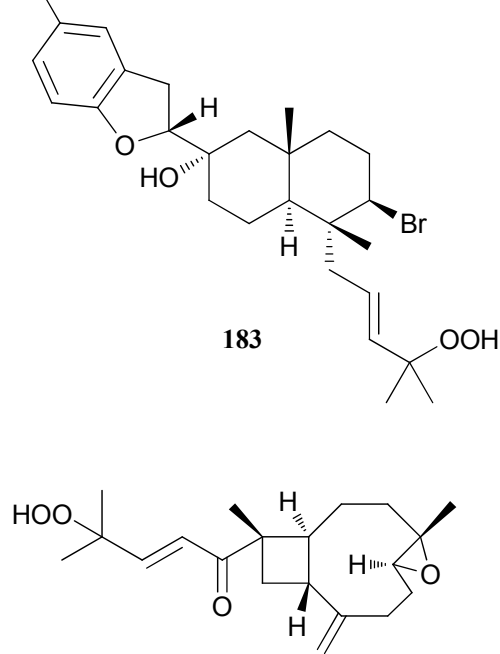

184<smiles>CC(C)[C@H]1C=C[C@H](O)[C@H]2[C@H]3[C@H](O)[C@@H](O)C[C@@H](Br)[C@@]3(C)CC[C@]12CBr</smiles>

$\mathrm{HOO}$<smiles>CC(C)[C@H]1C[C@@H](C)C=C2[C@H]3[C@](C)(CC[C@@]21CBr)[C@@H](Br)C[C@H](O)[C@]3(C)O</smiles>

194
185

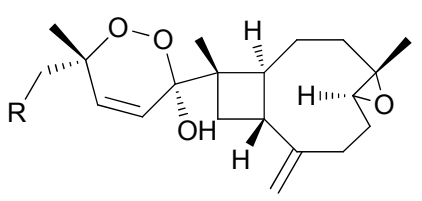

$186 \mathrm{R}=\mathrm{OAC}$

$187 \mathrm{R}=\mathrm{OH}$

$188 \mathrm{R}=\mathrm{H}$

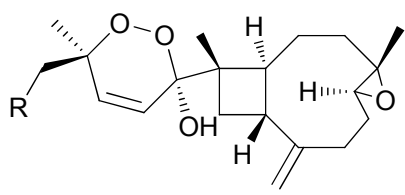

$189 \mathrm{R}=\mathrm{OAc}$ $190 \mathrm{R}=\mathrm{H}$

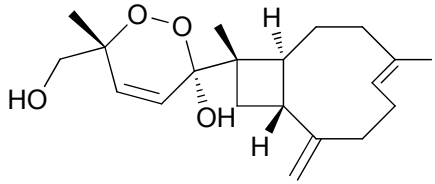

191

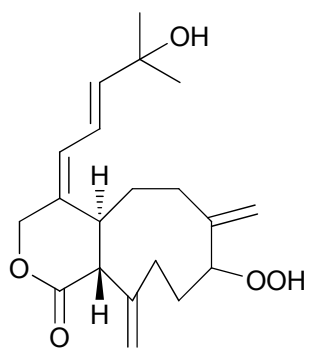

192

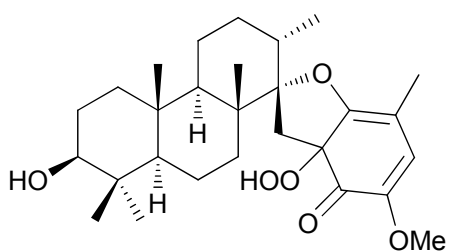

193

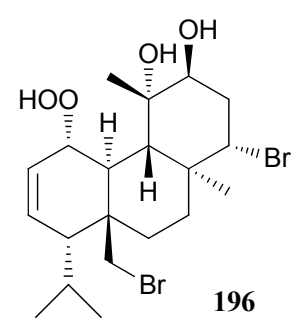<smiles>CC(C)[C@H]1C[C@@H](O)C=C2[C@@H]3[C@H](O)C[C@H](Br)[C@]2(CBr)CC[C@]3(C)[C@@H]1C</smiles><smiles>CC(=O)O[C@H]1CC/C(C)=C/[C@H]2OC(=O)[C@H](C)[C@]2(O)C(=O)[C@@]2(O)C(=O)[C@H](O)C[C@H](O)[C@@]12C(C)=O</smiles>

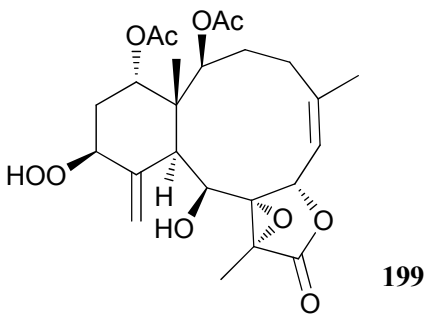<smiles>C=C[C@](C)(O)CCC1C2(C)CCC(O2)C1(C)C/C=C/C(C)(C)O</smiles><smiles>C=C[C@](C)(O)CCC1C2(C)CCC(O2)C1(C)C/C=C/C(C)(C)O</smiles><smiles>C=CC(O)(C=C)CCC1C2(C)CCC(O2)C1(C)CC[C@H](O)C(=C)C</smiles><smiles>C=C[C@](C)(O)CCC1C2(C)CCC(O2)C1(C)CCC(=O)C(C)(C)O</smiles>

Chemical investigation on the gorgonian coral Briareum sp. yielded a hydroperoxybriarane diterpene named briarenolide B 198 with a rare 9-ketobriarane moiety. ${ }^{12}$ The same group afforded a further related briarenolide D 199 from a cultured specimen of the same organism. ${ }^{113}$ Four diterpene compounds 
<smiles>CC1=C(CC/C(C)=C/C2(O)OC(=O)C(C)=C2CC/C=C(\C)CC23C[C@@H]2O3)CO1</smiles>

204<smiles>C=C1C[C@H]2CC[C@@](C)(OC1=O)[C@@H]1OC1(C)C/C=C\[C@](C)(C(=O)O)CC[C@@H](O)C2</smiles>

$20711 R$

$20811 S$<smiles>C=C1C(=O)O[C@H]2C(=O)[C@H](C)CC12CC1O[C@]1(C)C/C=C/[C@](C)(O)CCC[C@H](C)O</smiles>

213<smiles>C=C1C(=O)O[C@H]2[C@@H]1CC([C@H](C)CCCC(C)(O)O)O[C@H]2[C@@](C)(O)C/C=C\C</smiles>

216<smiles>C=C(CO)[C@H](CC[C@](C)(O)/C=C/CC(C)=CCC/C(C)=C/[C@@H](O)CO)[C@@H](C)O</smiles>

205<smiles>[R2][C@H]1CC[C@](C)(O)[C@@H]2C[C@H](CC[C@@]3(C)O[C@@H]23)[C@@H](C)C(=O)O1</smiles>

$209 \mathrm{R}_{1}=\mathrm{H}, \mathrm{R}_{2}=\mathrm{OOH}$

$210 \mathrm{R}_{1}=\mathrm{OOH}, \mathrm{R}_{2}=\mathrm{H}$

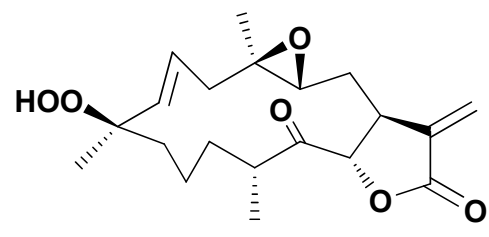

214<smiles>C=C1C(=O)C1C[C@H]1O[C@@]1(C)C/C=C/[C@@](C)(O)CCC[C@@H](C)[C@@H](O)[C@H]1OC(=O)C(=C)[C@H]1O</smiles>

217<smiles>C=C(C(C)=O)[C@H]1C[C@@H]2OC2(C)C/C=C/[C@@](C)(O)CCC2OC2(C)C[C@@H]1O</smiles>

206<smiles>[R2]C1([R2])C=CC[C@](C)(O)[C@H]2C[C@H](CC[C@]3(C)O[C@@H]3C2)[C@@H](C)C(=O)O1</smiles>

$211 \mathrm{R}_{1}=\mathrm{OOH}, \mathrm{R}_{2}=\mathrm{CH}_{3}$

$212 \mathrm{R}_{1}=\mathrm{CH}_{3}, \mathrm{R}_{2}=\mathrm{OOH}$

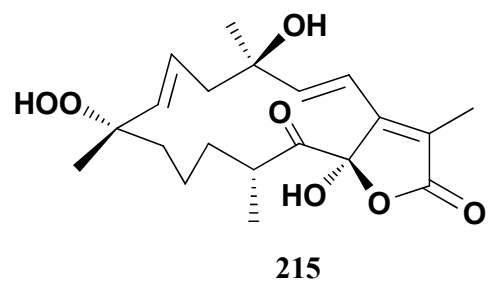

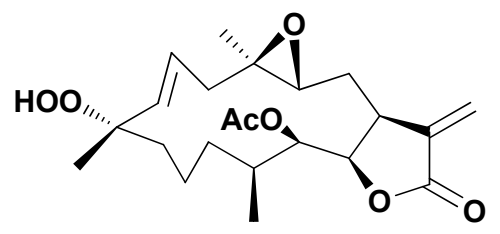

218
200-203 representing a new skeletal type, the dactylomelanes, have been found from specimens of Laurencia sp. ${ }^{114}$

A large number of highly functionalized cembranoid diterpenes and related metabolites have been isolated and identified from marine soft corals, especially from the genera Lobophytum, Sarcophyton, and Sinularia. A hydroperoxysubstituted cembranoid diterpene, 2-hydroperoxysarcophine 204, was isolated from South-China-Sea soft coral L. crassum. It remains unclear whether $\mathbf{2 0 4}$ is a true natural product or an artifact. ${ }^{115}$ One further cembranoid, crassumolide E 205, was found from the same species. ${ }^{116}$ A Kenting (Taiwan) collection of Sinularia flexibilis contained the cembranoid hydroperoxide flexilarin C 206. ${ }^{117}$ The same group provided two further structurally-related $\varepsilon$-lactones sinuladiterpenes A 207 and B 208 from the same species. ${ }^{118}$ The Taiwanese soft coral $S$. manaarensis contained four cembrane-type diterpenoids, manaarenolides A 209 and B 210 and manaarenolides E 211 and F 212, which were discovered for the first time as the hydroperoxycembranolides possessing a $\delta$-lactone ring. ${ }^{19}$ Four $\gamma$-cembranolide-type diterpenes, uprolides H-J 213-214<smiles>C=C1C(=O)OC(C(C)CCC[C@](C)(O)/C=C\CC(C)C)C1CC1O[C@]1(C)O</smiles><smiles>C=C1C(=O)OC(C(C)C)C1CC1OC1(C)CCCC(C)(C)O</smiles>

219

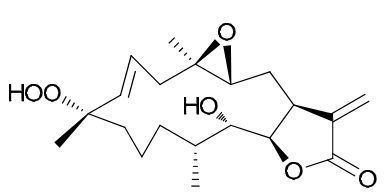

221

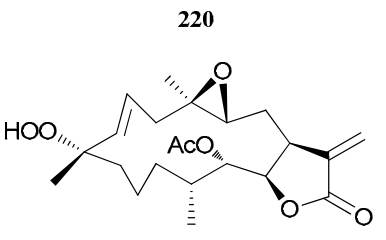

222

and L 215 and M 216, were reported from Eunicea pinta collected from San Andrés Island, Colombia. This study also led to the revision of the structures for nine previously reported uprolide $\mathrm{B}$, uprolide $\mathrm{B}$ acetate, 8-epi-uprolide $\mathrm{B}$, uprolide $\mathrm{C}$ acetate, 8-epi-uprolide B acetate, ${ }^{120}$ 12,13-bis-epiuprolide B, 12,13-bisepiuprolide $B$ acetate, uproeunicin, and uprolide $C^{121}$ to 217-225, respectively. ${ }^{122}$ Another compound of the type 
226 was isolated from the soft coral Sarcophyton crassocaule collected from the Xisha Islands in South China Sea. It exhibited strong cytotoxicity against the P388 cell line with an $\mathrm{IC}_{50}$ value of $0.1 \mu \mathrm{g} / \mathrm{mL} .^{123}$ The same source, $S$. crassocaule, provided three further cembranoid sarcocrassocolides F 227, G 228, and J 229, all of which inhibited LPS-induced upregulation of the pro-inammatory protein iNOS. ${ }^{124}$ A chemical investigation of another species of the same genus, S. Glaucum, has led to the isolation of two peroxide diterpenes $\mathbf{2 3 0}$ and $\mathbf{2 3 1}$, the absolute configuration of which were confirmed by X-ray diffraction and circular dichroism (CD) analyses. Compound 231 was found to be promising inhibitors of cytochrome $\mathrm{P}_{450}$ $1 \mathrm{~A}$ activity as well as inducers of GST and QR activity in vitro assays. $^{125}$

A decalin-type bicyclic diterpenoid, lemnaloside C 232, has been obtained from an extract of the marine soft coral Lemnalia sp. ${ }^{126}$ The Japanese marine sponge Epipolasis sp. afforded a novel diterpene peroxypolasol 233. ${ }^{127}$ The Formosan soft coral Nephthea pacifica contained four prenylbicyclogermacrane diterpenoids, pacificins C 234, E 235, G 236, and H 237, of which 234 and 237 exhibited cytotoxicity against $\mathrm{P} 388$ cells with $\mathrm{ED}_{50}$ of 1.44 and 2.01 $\mu \mathrm{g} / \mathrm{mL}$, respectively. ${ }^{128}$

2.5 Other Marine Metabolites: The Hainan Sponge Dysidea septosa contained a new sesquiterpene lingshuiperoxide 238. ${ }^{129}$ Three isothiocyanate sesquiterpenes axinisothiocyanates $\mathrm{H} 239$ and I 240, axinisothiocyanate N 241, and aristolane derivative axinysone C 242 have been obtained from a sponge of the genus Axinyssa collected in the<smiles>C=C1C(=O)OC2OC([C@](C)(O)C/C=C\[C@](C)(O)CCC[C@H](C)O)CC12</smiles>

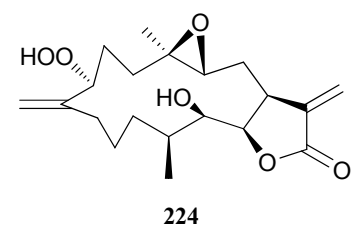<smiles>C=C1CCC(O)C(C)C(C2OC(=O)C2=C)C1CC1OC1(C)CCCC(=O)O</smiles>

Gulf of California by the same authors. Axinisothiocyanate N were mildly cytotoxic. ${ }^{130,131}$

Hydroperoxides have rarely been found in algae: two examples, dictyohydroperoxide $\mathbf{2 4 3}$ and hydroperoxyacetoxycrenulide 244, were isolated from Dictyota dichotoma (Troitsa Bay, Sea of Japan, Russia). ${ }^{132}$ A aromandendrane sesquiterpenoid $\mathbf{2 4 5}$ was isolated from the Formosan soft coral ClaVularia inflata. ${ }^{133}$ Chemical investigations of the soft coral Nephthea erecta have afforded three new sesquiterpenoids 246-248, of which, 247 and 248 exhibited significant cytotoxicty against P388 and HT-29. ${ }^{134}$ The Formosan soft coral Nephthea erecta provided the sesquiterpenoid 249. ${ }^{135}$ Five sesquiterpene peroxides sinularioperoxides 250-254 have been isolated from a Formosan soft coral of the genus Sinularia by the same group. ${ }^{136,137}$

An unusual 1,2-dioxolane-3-ol-containing sesquiterpene,<smiles>C=C1C(=O)O[C@H](C[C@@](C)(O)CCC[C@](C)(O)C/C=C/C2(C)O[C@@H]2C)[C@@H]1C</smiles>

226

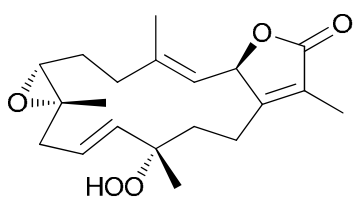

231<smiles>CC(C)(O)/C=C/C[C@]1(C)CC[C@]2(C)O[C@H]2CC[C@@](C)(O)[C@@H]2C[C@H]21</smiles>

234

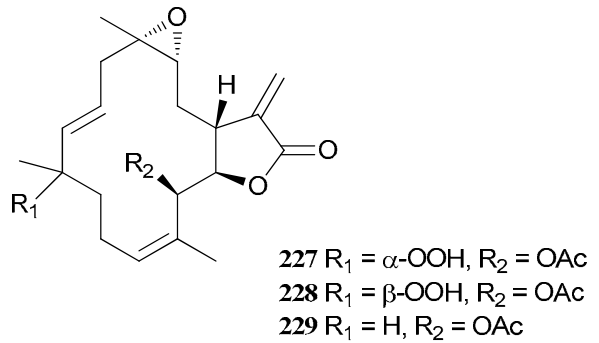

$\mathrm{AcO}$

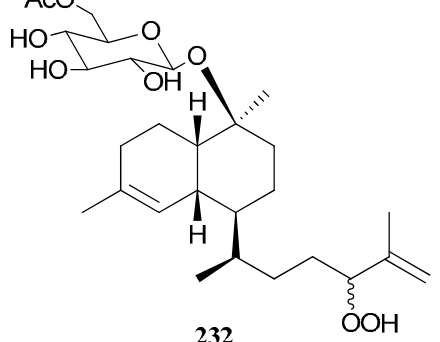

232<smiles>C=C(C)C(CC[C@]1(C)CC[C@@]2(C)O[C@H]2C[C@H]1[C@H]1C[C@@H]1C)OO</smiles>

235<smiles>CC(=O)O[C@H](/C=C(/C)CC[C@]1(C)C[C@H]1[C@H](C)O)C/C=C/C(C)(C)O</smiles>

236<smiles>C=C(CCC1=C(C)C(=O)OC1/C=C/CC[C@H]1[C@@H]2CC[C@@H](O)[C@@H]1O2)C(=O)O</smiles>

230 233

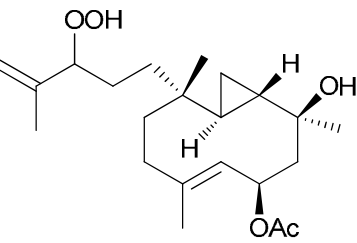

237 
<smiles>C[C@@H]1[C@@H]2C=C[C@@](C)(O2)[C@]1(CO)CCC1=CC(O)OC1=O</smiles>

238<smiles>C=C1CC[C@H](C(C)CC[C@H](O)C(C)(C)Cl)[C@H](O)[C@@]2(C)[C@H](O)C=C[C@H]12</smiles>

243<smiles>C=C1CC[C@H]2[C@@H](C)[C@H]2[C@H]2C(C)=CCC12OO</smiles>

245<smiles>CC1=C/C(=C/C2(C)CCC(/C(C)=C/CO)OO2)OC1=O</smiles>

251<smiles>C=CC(C)(O)C1CC[C@](C)(/C=C2/C=C(C)C(=O)O2)OO1</smiles>

254<smiles>[R2]C1([R2])CC[C@](C)(N[Si])[C@@H]2CC[C@@](C)(O)C=C21</smiles>

$239 \mathrm{R}_{1}=i$ - $\mathrm{Pr}, \mathrm{R}_{2}=\mathrm{OOH}$

$240 \mathrm{R}_{2}=\mathrm{OOH}, \mathrm{R}_{1}=i$-Pr<smiles>CC(=O)O[C@H]1C[C@@H](C)C2C[C@H]2C2=C(COC2=O)[C@H]1[C@H](C)/C=C/C(C)(C)O</smiles>

244

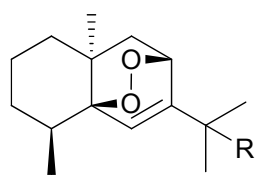

$246 \mathrm{R}=\mathrm{OH}$

$247 \mathrm{R}=\mathrm{OOH}$<smiles>CC1=C/C(=C/C2(C)CCC(/C(C)=C/CO)O2)OC1=O</smiles>

252

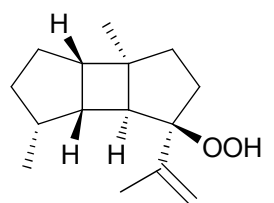

248<smiles>C[C@H]1[C@H](C)[C@@]23C(=CC(=O)[C@@H]12)[C@H](O)CC[C@H](C)[C@H]3C</smiles>

242<smiles>CC1=C/C(=C/C2(C)CCC(/C(C)=C/CO)OO2)OC1=O</smiles>

250<smiles>C/C(=C\CO)C1CCC(C)(/C=C2\C=CC(=O)O2)OO1</smiles>

253<smiles>CC1CCC2=C1C=C1C(C)(C)OOC1(O)C[C@@H]2C</smiles>

255<smiles>COC(C)(C)C1=CC23OO[C@]2(C)CCC[C@]3(C)CC1</smiles>

249 dioxosarcoguaiacol 255, was reported from an Egyptian (Red Sea) collection of Sarcophyton glaucum. ${ }^{138}$ A Dysidea sp. from the Great Barrier Reef contained a cytotoxic sesquiterpene 256, the structure of which was determined by single crystal X-ray analysis. ${ }^{139}$ Bioassay-guided fractionation of the Okinawan marine sponge Dysidea chlorea afforded two tricyclic spiro-sesquiterpenes, haterumadysins C and D 257 and 258, both of which may be isolation artifacts. ${ }^{140}$ One cuparene-derived sesquiterpene, laureperoxide 259, has been reported from the red alga Laurencia okamurai. ${ }^{141}$ The guaiane derivative peroxygibberol $\mathbf{2 6 0}$ has been obtained from the Formosan soft coral, Sinularia gibberosa, which was found to exhibit moderate cytotoxicity toward a human liver carcinoma cell line. ${ }^{142}$

The sipholane-type triterpenoids, sipholenol M 261 , siphonellinol E 262, and siphonellinol hydroperoxide 263, were isolated from the red sea sponge Callyspongia (Siphonochalina) siphonella. ${ }^{143}$ Although there are several documented natural plant-derived triterpene hydroperoxides in the literature, it is also plausible that these three compounds are artifactual oxidation by products generated during the extraction and isolation process. Bruguiera gymnorrhiza yielded a dammarane-skeletoned triterpene bruguierin C 264 that activated antioxidant response element with micromolar potency. ${ }^{144}$ 
<smiles>CC(=O)O[C@H]1OC=C[C@]12CC1=C[C@](C)(O)CC[C@H]1[C@H]2C</smiles>

257<smiles>CC(=O)O[C@H]1OC=C[C@]12CC1=C[C@](C)(OO)CC[C@H]1[C@H]2C</smiles>

258<smiles>Cc1cc2c(cc1Br)[C@@]1(C)CC[C@@H](C)[C@]1(CO)O2</smiles>

259<smiles>CC(C)[C@]12C=C3[C@@](C)(O)CC[C@]3(OCCC[C@H]1C)O2</smiles>

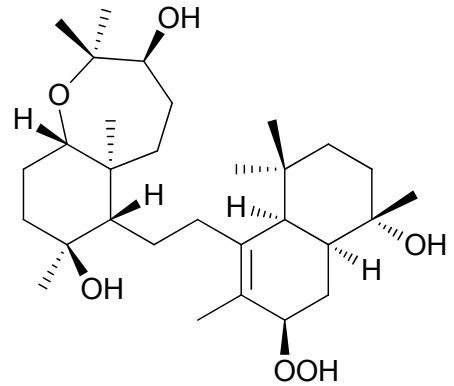

261

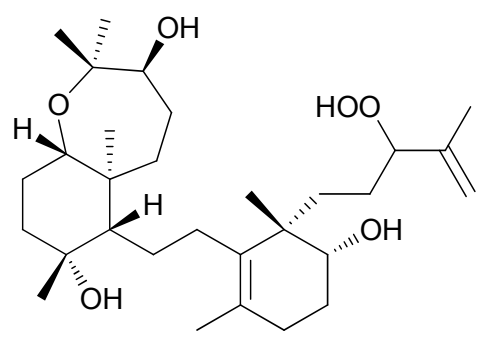

262<smiles>CC1=C(CC[C@H]2[C@@H](C)CC[C@@H](C)[C@@]2(C)O)[C@](C)(C/C=C/C(C)(C)O)[C@@H](O)CC[C@H]1O</smiles>

263

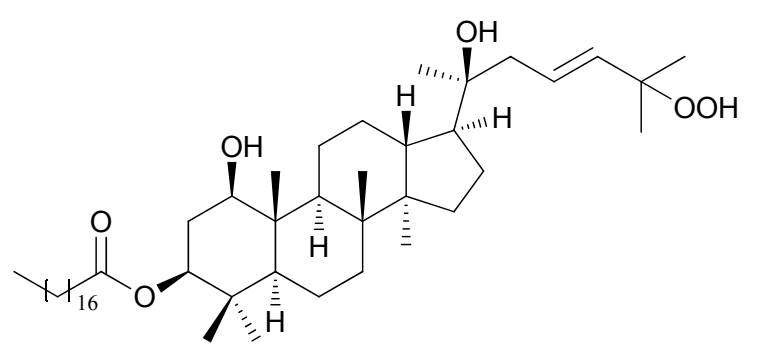

264<smiles>C=C(/C=C(\C)c1oc(OC)c(C)c(=O)c1C)C(O)O</smiles>

265

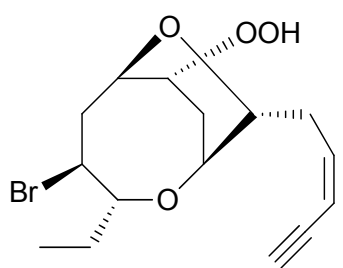

266
A Mediterranean collection of Placida dendritica afforded an unprecedented hydroperoxide $\mathbf{2 6 5}$. Whether the hydroperoxide is an artifact of isolation, or a true natural product is unclear. ${ }^{145}$ One halogenated nonterpenoid $\mathrm{C}_{15^{-}}$ acetogenin, laurendecumenyne A $\mathbf{2 6 6}$, has been reported from the Marine Red Alga Laurencia decumbens. ${ }^{146}$

Dihalenaquinolides A $\mathbf{2 6 7}$ and B 268, from the Taiwanese marine sponge Petrosia elastica, have an unusual peroxide linkage between two meroterpenoid units. ${ }^{147}$ Bioassay-guided fractionation of the marine cyanobacterium Lyngbya sp. led to the isolation of biselyngbyasides C 269 and D 270, whose stereochemistries were established based on NOESY spectra and $\mathrm{CD}$ data. ${ }^{148}$

Two prenylated indole diketopiperazine alkaloids, spirotryprostatin E 271 and 13-oxoverruculogen 272, have been obtained from the fermentation of Aspergillus fumigatus from a holothurian, Stichopus japonicus (Lingshan Is., Qingdao, China). ${ }^{149}$ The antimalarial gracilioether A 273, from the sponge Agelas gracilis (Oshima-Shinsone, Japan), are of mixed acetate/butanoate origin. ${ }^{150}$ The sponge Plakinastrella mamillaris was a new source for gracilioether A 273. ${ }^{151}$ The same source, P. Mamillaris, afforded additional antimalarial gracilioether H 274 structurally related to gracilioether A. The existence of endoperoxide ring is important for the antimalarial activity. ${ }^{152}$
A collection of the sacoglossan Placobranchus ocellatus from the Philippines provided three propionate-derived metabolites, tridachiapyrone $\mathrm{J} \mathbf{2 7 5}$, and tridachiahydropyrones B 276 and C 277, all of which are probably artifacts from oxidation during storage or workup. ${ }^{53}$ Several years later, tridachiahydropyrones $\mathrm{B}$ and $\mathrm{C}$ were proved to be the same compound characterized as $\mathbf{2 7 8}$. $^{154}$ The same species, $P$. ocellatus, provided the possibly artefactual peroxy derivative 279, ${ }^{155}$ whose relative configuration was confirmed at the same year. ${ }^{156}$ A Panamanian collection of the sacoglossan mollusc Elysia diomedea yielded the endoperoxide 280, structurally closely related to $279 .{ }^{157}$ The observation of rearrangement of $\mathbf{2 8 0}$ with triethylamine to yield the known vicinal diexpoxide elysiapyrone $A^{158}$ prompted speculation of the biosynthetic intermediate of $\mathbf{2 8 0}$, likely to be in turn derived from a putative polypropionate alkenyl chaincontaining precursor reacting with singlet oxygen.

\section{Terrestrial Sources}

3.1 Monoterpenoids: One $p$-menthane hydroperoxide, $(1 R, 4 S)$-1-hydroperoxide- $p$-menth-2-en-8-ol-acetate 281 with strong trypanocidal avtivity, was isolated from the leaves of Laurus nobilis. ${ }^{159}$ The same group afforded four further monoterpene hydroperoxides 282-285 with trypanocidal activity from Chenopodium ambrosioides. These hydroperox- 


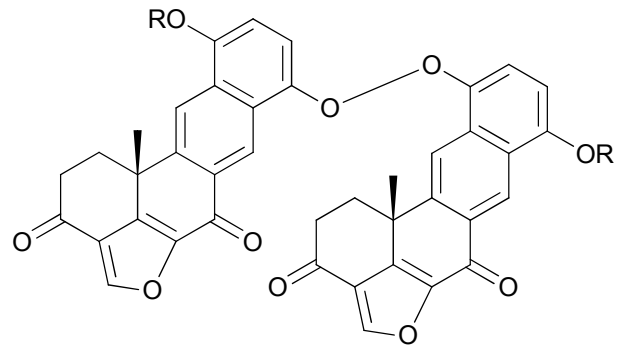

$267 \mathrm{R}=\mathrm{CH}_{3}$ $268 \mathrm{R}=\mathrm{CH}_{2} \mathrm{CH}_{3}$

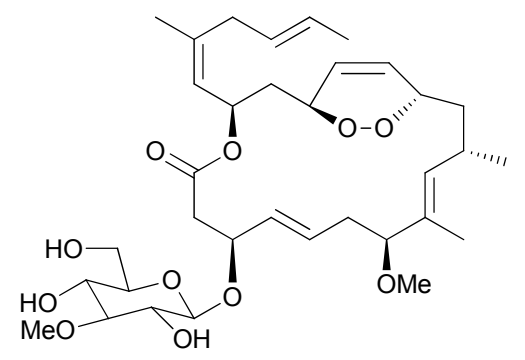

269

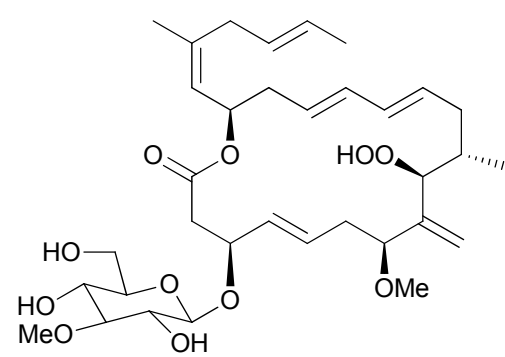

270<smiles>COc1ccc2c(c1)N(/C=C/C(C)(C)O)C(=O)[C@@]21C(=O)[C@@H](C=C(C)C)N2C(=O)[C@@H]3CCCN3C(=O)[C@@]2(O)[C@@H]1O</smiles>

271<smiles>C=C([C@@H](O)CC)[C@@H]1C(C)=CC(C)=C[C@]1(C)c1oc(OC)c(C)c(=O)c1C</smiles>

275<smiles>COC1=C(C)C(=O)C23OC(C)(C=C2C)[C@H](/C(C)=C/CC(C)C)C13O</smiles>

278

ides are likely formed through the singlet-oxygen oxidation of limonene, and the hydroperoxy group is essential for their trypanocidal activities. ${ }^{160}$ The liverwort Riella helicophylla yielded six new monoterpenes 286-291. ${ }^{161}$ The aerial part of Aster scaber afforded two monoterpene peroxide glycosides 291-293. ${ }^{162}$ A cyclic monoterpene peroxide 294 with the irregular santolinyl framework was found from aerial parts of Artemisia fragrans. ${ }^{163}$ The complete stereostructure of 295 has been established by application of the modified Mosher method. ${ }^{164}$

Catharoseumine 296, a monoterpenoid indole alkaloid

\section{照 Springer}
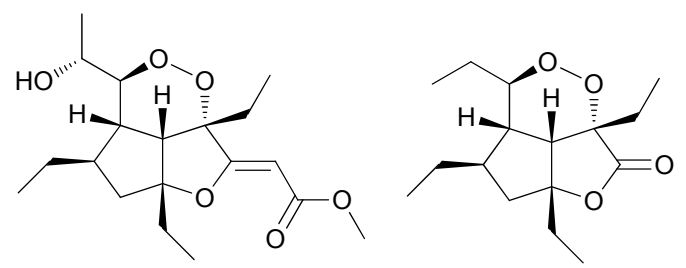

273

274<smiles>COC1=C(C)C(=O)C2(C)OC13OOC2(C)C=C3C</smiles>

277

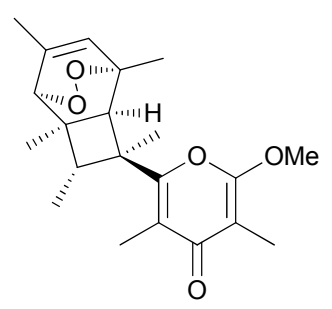

280

possessing a unique peroxy bridge moiety, was isolated from the whole plants of Catharanthus roseus. Its absolute configuration was determined by ECD and chemical methods. Catharoseumine exhibited cytotoxicity against HL-60 cell line with $\mathrm{IC}_{50}$ value of $6.28 \mu \mathrm{M}$ and potential inhibition against Plasmodium falciparum falcipain $2\left(\mathrm{IC}_{50}=4.06 \mu \mathrm{M}\right)$. A plausible biogenetic pathway of catharoseumine was also proposed. ${ }^{165}$

\subsection{Sesquiterpenes}

3.2.1 Guaianes: Three highly oxygenated guaianolides 297-299 were isolated from the aerial parts of Ajania 
<smiles>CC(=O)OC(C)(C)[C@H]1C=C[C@@](C)(O)CC1</smiles><smiles>C=C1CC[C@@H](C(=C)C)C[C@H]1O</smiles>

282<smiles>Cc1ccc(C(C)(C)O)cc1O</smiles>

287<smiles>CC12C=CC(C(C)(C)O)(CC1)OO2</smiles>

288<smiles>C=C1CC[C@@H](C(=C)C)C[C@H]1O</smiles>

283<smiles>CC12C=CC(C(C)(O)O)(CC1)OO2</smiles><smiles>C=C(C)[C@H]1C=C[C@@](C)(O)CC1</smiles>

284<smiles>C=C(C)C1(O)C=CC(C)(OO)CC1</smiles>

290<smiles>C=C(C)[C@H]1C=C[C@@](C)(O)CC1</smiles>

285<smiles>C[C@]1(O)C=CC(=O)CC1</smiles>

291<smiles>CC1=CCC(C(C)(C)O)=CC1</smiles>

286<smiles>C=C(C)[C@H]1OO[C@@H](CO)[C@H]1C(C)(C)O[Ge]</smiles>

294<smiles>C=C[C@](C)(C/C=C/C(C)(C)O)OC1OC(CO)C(OC(=O)/C(=C\C)C(=O)OC)C(O)C1OC(=O)/C(C)=C\C</smiles>

292

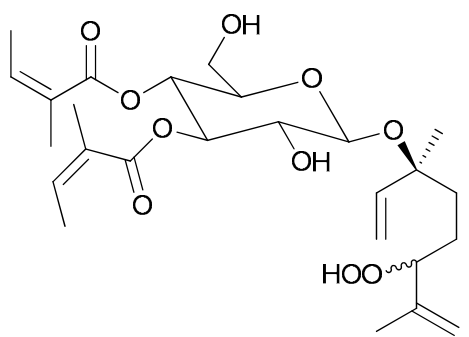

293<smiles>C=C(C)[C@@H](O)[C@H]1[C@@H](CO)[C@H]1C(C)(C)O</smiles>

295 fruticulosa. Compund 299 was inhibitory to the growth of Candida albicans with MICs being $20 \mu \mathrm{g} / \mathrm{mL} .{ }^{166,167}$ The aerial parts of Achillea setacea afforded a guaianolide $\mathbf{3 0 0}$ containing an endoperoxide ring. ${ }^{168}$ Two guaianolides, anthemolide B 301 and 8-O-angeloyl-9-O-acetylanthemolide B 302, were identified from the aerial parts of the flowering plant Anthemis cretica. ${ }^{169}$ A cytotoxic sesquiterpene lactone, lactucin-8-O-p-methoxyphenyl acetate 303, has been obtained from Mulgedium tataricum. ${ }^{170}$ The structure of $1 \alpha, 8 \alpha-$ epidioxy-4 $\alpha$-hydroxy-5 $\alpha$ H-guai-7(11),9-dien-12,8-olide $\mathbf{3 0 4}$, isolated from Curcuma wenyujin with anti-influenza viral activity, has been confirmed by single-crystal X-ray diffraction experiment. ${ }^{171}$ The complete relative configuration of the known sesquiterpene (+)-dioxo-sarcoguaiacol has been established. This compound has now been isolated from Acorus calamus. ${ }^{172}$

Chemical examinations of the roots of Nardostachys chinensis afforded two antimalarial guaiane endoperoxides, nardoperoxide 305 and isonardoperoxide 306, whose absolute stereochemistries were determined by $\mathrm{CD}$ spectra. The endoperoxide moiety of the molecules was assumed to relate to the antimalarial activity. ${ }^{173} \mathrm{~A}$ subsequent report described another four related endoperoxides nardoguaianones A-D 307-310 from the same plant. ${ }^{174}$ Three hydroperoxides 311313 with trypanocidal activity have been isolated from Pogostemon cablin, ${ }^{175}$ whilst the sesquiterpene peroxide $\mathbf{3 1 4}$ has been found from the aerial parts of Croton arboreous. ${ }^{176}$

3.2.2 Eudesmanes: The aerial parts of Montanoa hibiscifolia afforded three eudesmanolides 315-317 with a rare endoperoxide structural element. ${ }^{177}$ The novel eudesmanolide 318 has been isolated from Atractylodes macrocephala. ${ }^{178}$ The aerial parts of Aster spathulifolius was the source for two cytotoxic sesquiterpene hydroperoxides, $7 \alpha$-hydroperoxy-3,11-eudesmadiene 319 and $7 \beta$-hydroperoxyeudesma-11-en-4-ol 320. ${ }^{179,180}$ The sesquiterpene schisansphene A 321 was identified from the species Schisandra sphenanthera. ${ }^{181}$ A eudesmane derivative hydroperoxygynuradiene $\mathbf{3 2 2}$ has been obtained from the root of Gynura bicolor. ${ }^{182}$ Another two compounds of this type $\mathbf{3 2 3}$ and $\mathbf{3 2 4}$ were discovered from Xylopia emarginata and Ecdysanthera rosea, respectively. ${ }^{183,184}$

Two novel eudesmene-type sesquiterpene peroxides, kandenols C 325 and D 326, have been reported from Streptomyces sp. derived from the mangrove plant Kandelia candel. ${ }^{185}$ The aerial parts of Inula japonica contained two eudesmane sesquiterpenoids $\mathbf{3 2 7}$ and $\mathbf{3 2 8}$. Compound $\mathbf{3 2 8}$ was confirmed by means of single-crystal X-ray diffraction analysis. ${ }^{186}$ One eudesmane derivative $\mathbf{3 2 9}$ has been isolated from the liverworts Chiloscyphus polyanthus. ${ }^{187}$ Other eudesmane peroxides included $1 \beta, 14$-peroxy-4 $\alpha$-hydroxy$5 \alpha \mathrm{H}, 7 \alpha \mathrm{H}, 6 \beta \mathrm{H}$-eudesm-11(13)-en-6,12-olide $\mathbf{3 3 0}$ from the roots of Vladimiria souliei, ${ }^{188} 3 \alpha$-dehydroxy- $3 \alpha$-hydroperoxyclypeotriol 331 from Achillea clypeolata, ${ }^{189}$ and $5 \alpha-$ hydroperoxy-eudesma-4(15),11-diene $\mathbf{3 3 2}$ from Artemisia annua. 190

3.2.3 Bisabolanes and Germacranes: Four bisabolane-type sesquiterpenes, peroxylippidulcines $\mathrm{A}-\mathrm{C} \quad \mathbf{3 3 3}-\mathbf{3 3 5}$ and 
<smiles>C=C1C(=O)O[C@H]2[C@H]1C[C@@H](OC(=O)/C(C)=C\C)[C@@](C)(O)[C@@]1(O)C=C[C@@](C)(O)[C@H]21</smiles>

297<smiles>C[C@H]1[C@@H](O)[C@@H]2[C@@H](CO)C(=O)O[C@H]2[C@H]2[C@@H](CO)C=C[C@]1(O)[C@]2(C)O</smiles>

298<smiles>C=C1C(=O)O[C@@H]2O[C@@]3(C)[C@@H](O)[C@@H]4O[C@]43[C@@](C)(O)C[C@H](O)[C@@H]12</smiles>

299

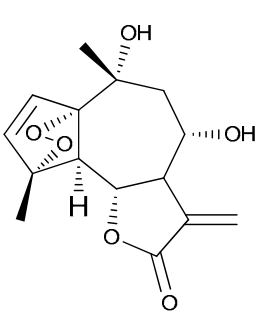

300

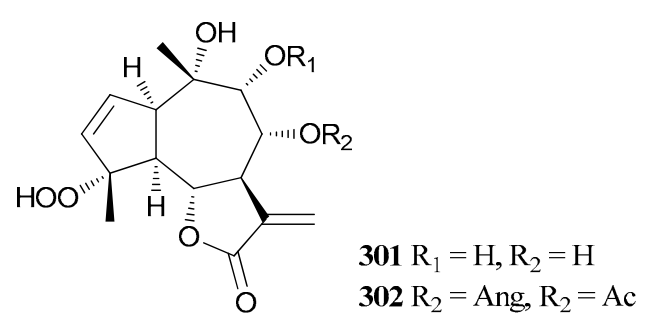<smiles>CC(C)[C@@H]1CC[C@@]2(C)OO[C@]1(C)C1=C2C(=O)C[C@H]1C</smiles>

305<smiles>CC(C)[C@@]12OO[C@@](C)(C[C@@H]1O)C1=C([C@H](C)CC1=O)[C@H]2O</smiles>

310

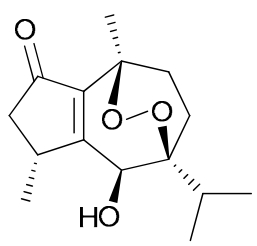

306

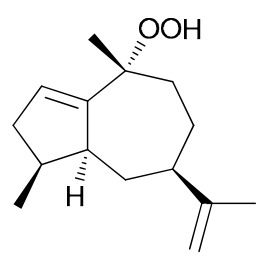

311<smiles>C=C1C(=O)O[C@H]2C3C(CO)=CC(=O)C3=C(C)C[C@H](OC(=O)Cc3ccc(OC)cc3)[C@@H]12</smiles>

303

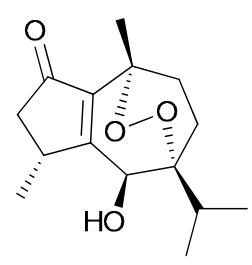

307

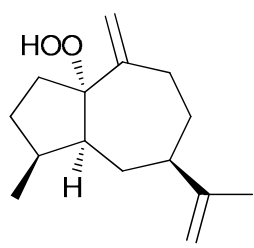

312

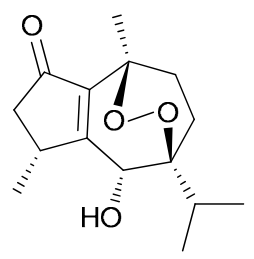

308<smiles>C=C(C)[C@@H]1CCC(CO)=C2CC[C@H](C)[C@H]2C1</smiles>

313

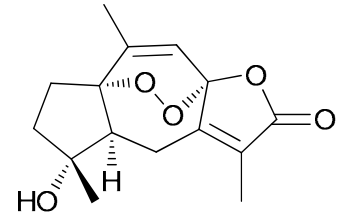

304 peroxyepilippidulcine B 336, have been obtained from the aerial parts of Lippia dulcis. The relative configurations of $\mathbf{3 3 4}$ and 336 were confirmed by X-ray crystallographic analysis data. ${ }^{191}$ The aerial parts of Carthamus lanatus afforded two oxygenated bisabolane fucosides 337 and 338. ${ }^{192}$ Another species of the genus, C. glaucus, contained two bisabolane fucopyranosides 339 and 340. ${ }^{193}$ Another bisabolene derivative 341 was found from the aerial parts of Achillea clavennae. ${ }^{194}$

A germacranolide peroxide $\mathbf{3 4 2}$ was identified as a component of mulgedium tataricum. ${ }^{170}$ Chemical investigation of Santolina insularis afforded two germacrane sesquiterpene peroxides 343 and 344, which might derive from the formal photo-oxygenation of the corresponding $\Delta^{4,5}$ olefin, a reaction well precedented in medium-sized olefins. ${ }^{195}$

3.2.4 Sesquiterpene Dimers: A dimeric sesquiterpene lactone japonicone E $\mathbf{3 4 5}$ bearing a rare hydroperoxide group was obtained from the aerial parts of Inula japonica, which displayed strong inhibitory activity against LPS-induced
NO production in RAW264.7 macrophages. ${ }^{196}$ Further investigations of the same species afforded additional related dimeric sesquiterpene, japonicone $\mathrm{T}$ 346. ${ }^{197}$ The leaves of Xylopia vielana contained a dimeric guaiane peroxide named vielanin C $\mathbf{3 4 7}$ with a central cyclobutane ring that are generated from two equal guaiane moieties by $[2+2]$ cycloaddition. ${ }^{198}$ Two further related vielanins D $\mathbf{3 4 8}$ and E 349 were isolated from the same plant as epimeric mixtures. Both compounds consist of bridged ring systems formally representing the Diels-Alder products from the hypothetical guaiane-type monomers. ${ }^{199}$ Spicachlorantins C-F 350-353, new lindenane sesquiterpene dimers possessing a hydroperoxy group, were isolated from the roots of Chloranthus spicatus, whose absolute stereostructures were established by CD spectroscopic analyses. These compounds were considered to be biogenetic precursors of the corresponding hydroxyl derivatives of dimeric lindenane sesquiterpenoids distributed in Chloranthus plants. ${ }^{200}$ Another species of the genus, $C$. Japonicus, contained one more dimeric sesquiterpene peroxide $\mathbf{3 5 4}$, structurally related to $350-\mathbf{3 5 3}{ }^{201}$ 


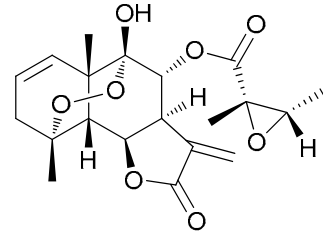

315<smiles>C=C(C)[C@]1(O)CC[C@]2(C)CCC=C(C)[C@H]2C1</smiles>

319<smiles>CC(C)[C@@H]1CC[C@@]2(C)[C@H]3C=C[C@@](C)(OO3)[C@]2(C)C1</smiles>

323<smiles>C=C1CC[C@@H](O)[C@]2(C)C[C@H]3OC(=O)C(C)[C@H]3C[C@]12OO</smiles>

327<smiles>C=C1[C@@H](O)CC[C@@]2(C)CC[C@@](CO)(C(C)(O)O)C[C@H]12</smiles>

331<smiles>C=C(C)[C@H](O)CC[C@H](O)[C@@H](C)C1CCC(C)=CC1=O</smiles>

335

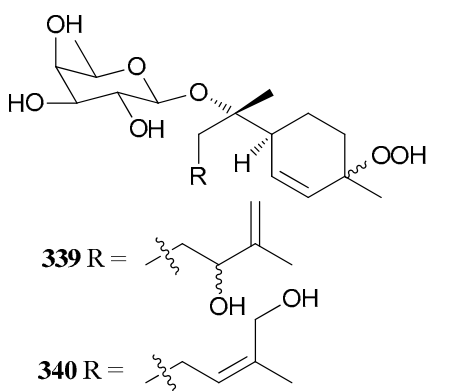

336<smiles>CC1=CCC([C@](C)(O)C/C=C/C(C)(C)O)CC1=O</smiles>

341

3.2.5 Other Sesquiterpenes: The structures of cytosporolides A-C 355- $\mathbf{3 5 7 ^ { 2 0 2 }}$ have been revised on the basis of synthetic studies and reinterpretation of the NMR data.<smiles>C=C(C)C1CCC2(C)CCCC(=C)C2(O)C1</smiles>

332

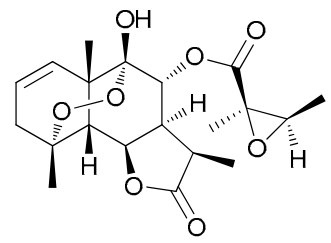

317

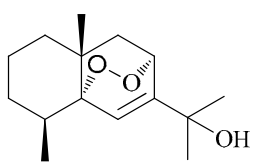

321

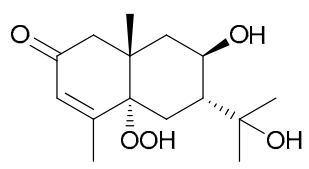

325

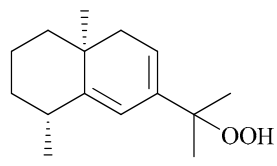

322

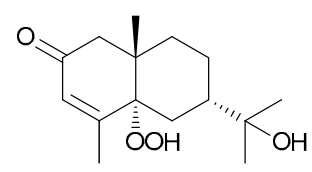

326<smiles>C=C1C2[C@@H](O)[C@@](O)(C(C)C)CC[C@@]2(C)CC[C@@H]1O</smiles>

329
337<smiles>CCOC(C)(C)[C@H]1CC=C(C)CC1</smiles>

338<smiles>C/C(=C/[C@H]1OC(=O)[C@](C)(O)C1CC/C=C(/O)[C@H](O)C[C@H](C)O)[C@H](C)O</smiles><smiles>[R9]C1C=C(C)CC[C@H](C(C)C)[C@H](O)[C@@H](O)C(=C)C1</smiles>

$343 \mathrm{R}=\mathrm{H}$ $344 \mathrm{R}=\mathrm{Ac}$

Cytosporolide A, which was originally assigned the strained nine-membered peroxylactone structure, has been revised to 358, which is probably biogenetically formed by a heteroDiels-Alder type cyclization. 

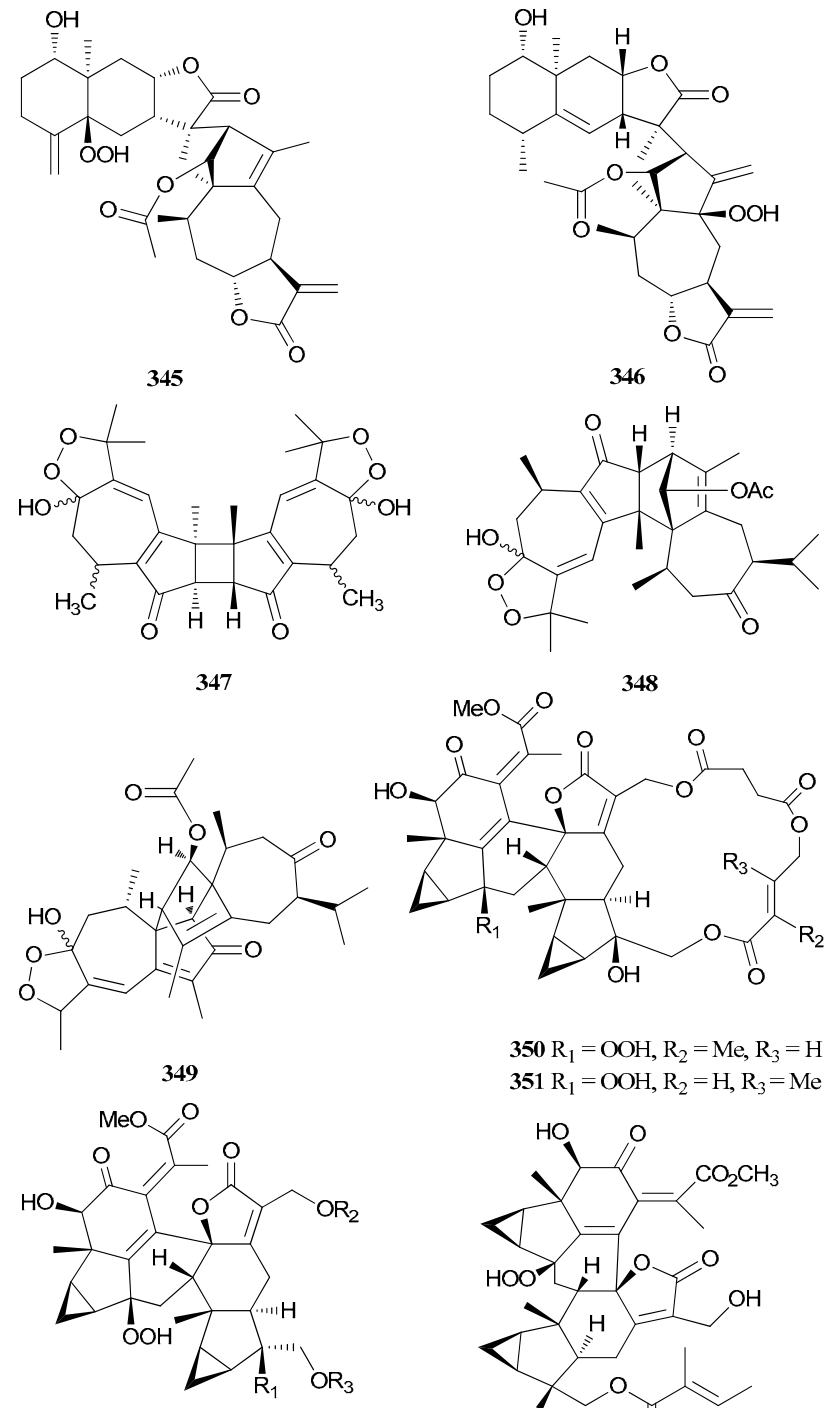

$352 \mathrm{R}_{1}=\mathrm{OH}, \mathrm{R}_{2}=\mathrm{Ac}, \mathrm{R}_{3}=$ Tig

$353 \mathrm{R}_{1}=\mathrm{H}, \mathrm{R}_{2}=\mathrm{H}, \mathrm{R}_{3}=\mathrm{Ac}$

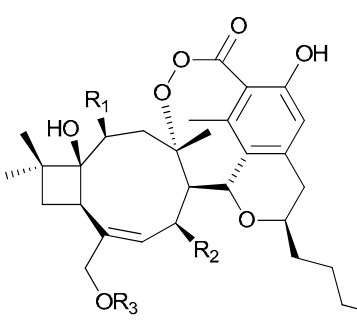

$355 \mathrm{R}_{1}=\mathrm{OH}, \mathrm{R}_{2}=\mathrm{OCH}_{3}, \mathrm{R}_{3}=\mathrm{H}$

$356 \mathrm{R}_{1}=\mathrm{H}, \mathrm{R}_{2}=\mathrm{OH}, \mathrm{R}_{3}=\mathrm{H}$

$357 \mathrm{R}_{1}=\mathrm{OH}, \mathrm{R}_{2}=\mathrm{OCH}_{3}, \mathrm{R}_{3}=\mathrm{Ac}$

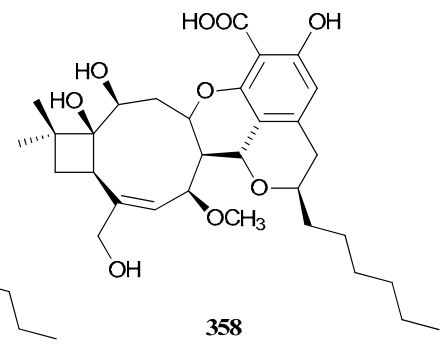

The novel norsesquiterpene peroxides steperoxides A-D 359-362 have been obtained from the mushroom Steccherinum ochraceum, ${ }^{204,205}$ while another nor-chamigrane merulin A, and the chamigranes merulins B-D 363-365, have been found in an extract of the culture broth of a Thai mangrove-derived fungus. ${ }^{206,207} \mathrm{We}$ have observed that steperoxide B and merulin A have the same structure $\mathbf{3 6 0}$. Among these isolated metabolites, merulin $\mathrm{C}$ exhibited potent antiangiogenic activity. Another four compounds of this type, talaperoxides A-D 366-369, have been obtained from Talaromyces flavus. Talaperoxides B and D were moderately cytotoxic to several human tumour cell lines. ${ }^{208}$ The structures of 359, 360, 366 and 367 were further confirmed by X-ray crystallographic analysis, and the absolute configurations of the latter three compounds were also determined using copper radiation $^{204,206,208}$

Five peroxy cuparene-type sesquiterpenoids 370-374 were identified from the Japanese liverwort Jungermannia infusca. The stereostructure of $\mathbf{3 7 0}$ was confirmed by X-ray crystallographic analysis. ${ }^{209,210}$ An inseparable diastereomeric mixture acetylmajapolene A $\mathbf{3 7 5}$ in the part of the peroxide with antibacterial activity have been found in an extract of an undescribed Malaysian species of the Laurencia genus, whose absolute configurations have been unambiguously determined as $(1 R, 4 R, 7 S, 10 S)$ and $(1 S, 4 S, 7 S, 10 S)$, respectively, by vibrational circular dichroism (VCD). ${ }^{211,212}$

Two novel muurolane sesquiterpene peroxides, 1,4-peroxymuurol-5-ene 376 and 1,4-peroxy-5-hydroxy-muurol-6-ene 377 have been obtained from Illicium tsangii. The absolute stereochemistry of $\mathbf{3 7 6}$ was confirmed by X-ray crystallography. ${ }^{213}$ A peroxy muurolane-type sesquiterpenoid 378 was isolated from the Belgium liverwort Scapania undulata. $^{214}$ The essential oil of the liverwort Plagiochila asplenioides contained one oxygenated sesquiterpene (+)muurolan-4,7-peroxide 379 . $^{215}$ The NMR data of the sesquiterpene peroxide $\mathbf{3 8 0}^{216}$ are also reported for the first time in the same paper. The aerial parts of the invasive plant Eupatorium adenophorum contain the new sesquiterpene 381. ${ }^{217}$ Dihydroartemisinic acid hydroperoxide $\mathbf{3 8 2}$ was isolated for the first time as a natural product from the plant Artemisia annua. The compound is a probable precursor of artemisinin under nonenzymatic conditions. ${ }^{218}$ The same plant, A. annua, afforded a rare seven-membered endoperoxide lactone arteannuin $\mathrm{H} \mathrm{383}$, a biomimetic synthesis of which has confirmed biogenetic speculations regarding its formation from a secondary allylic hydroperoxide. ${ }^{219,220}$ The structure of 384, isolated from the leaves of Eupatorium adenophorum, was determined by single-crystal X-ray crystallography. ${ }^{221}$

A phytochemical study of Robinsonecio gerberifolius afforded a eremophilane derivative $\mathbf{3 8 5}$, whose absolute configuration was established from CD analysis. ${ }^{222}$ Three species of the Ligularia genus, L. subspicata, L. Kanaitzensis, and L. Veitchiana, provided the eremophilane peroxides 386, 387, and 388, respectively. ${ }^{223-225}$ Another compound of this type 389 was isolated from Cacalia tangutica. ${ }^{226}$

The aerial parts of Anthemis arvensis contained two irregular linear sesquiterpene lactones 390 and 391, both of which were re-isolated from the same plant by another group of researchers. ${ }^{227,228}$ A different species of Anthemis, A. cotula, afforded additional related peroxide, 5-hydroperoxy-6,13dehydro-5,6-dihydroanthecotuloide 392. ${ }^{229}$

Three isomeric sesquiterpene hydroperoxides 393-395 were isolated from Illicium tsangii. These compounds appear to be derived from the ene-type addition of molecular oxygen to the known compound $\alpha$-santalene. ${ }^{230}$ A bioassay-guided fractionation of extract from Scleria striatinux led to the

\section{照 Springer}




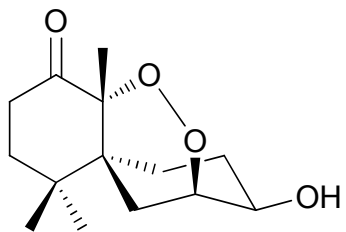

359

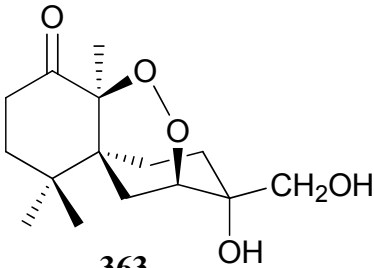

363

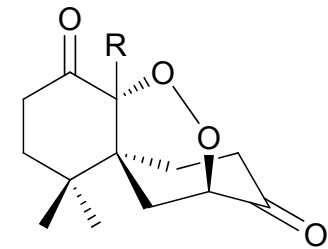

$368 \mathrm{R}=\alpha \mathrm{CH}_{3}$ $369 \mathrm{R}=\mathrm{BCH}_{3}$
373
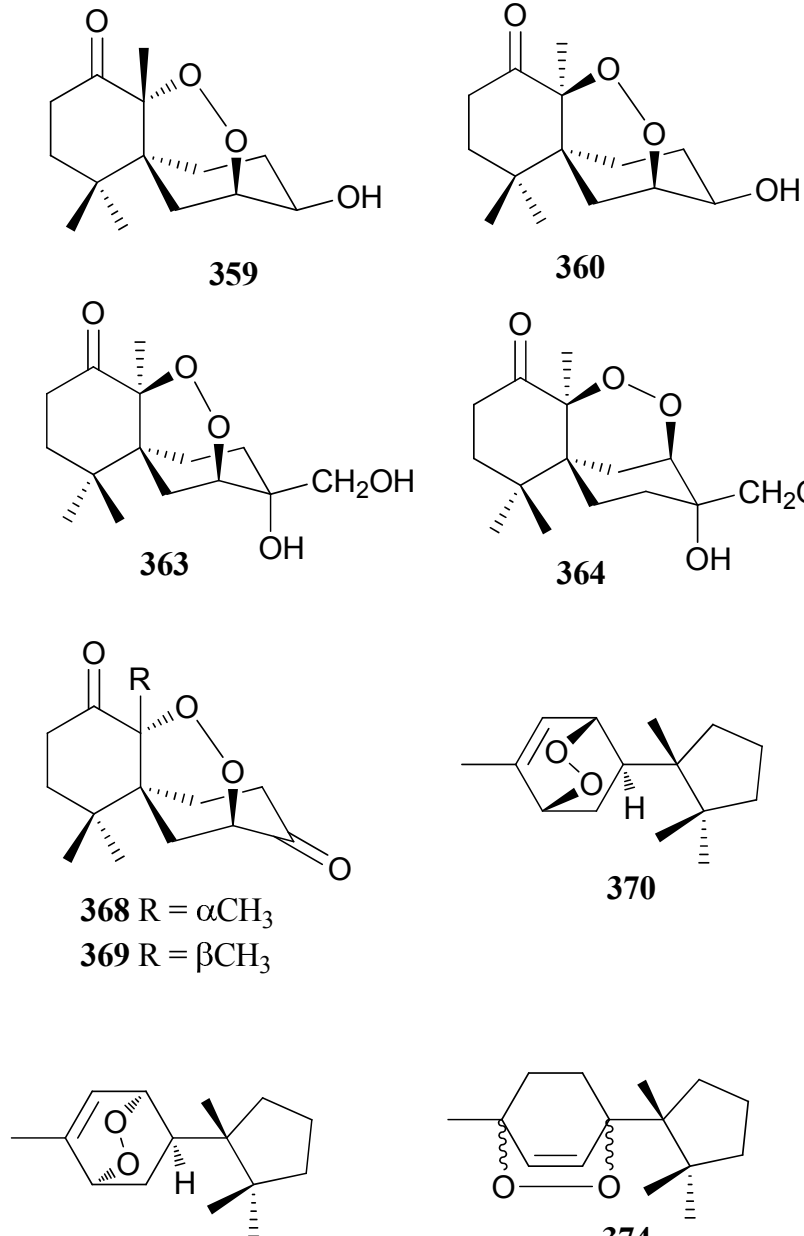

360

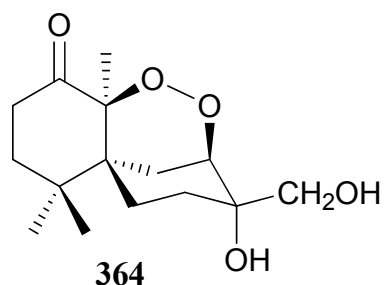

364

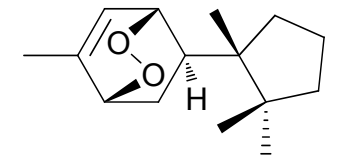

370

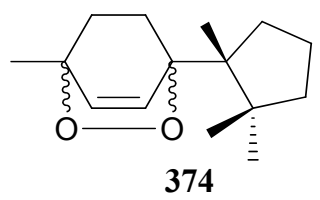

396, a compound with antiplasmodial activity. ${ }^{23}$

The aerial parts of Xanthium strumarium contained one xanthane-type sesquiterpenoid, $4 \beta, 5 \beta$-epoxyxanthatin- $1 \alpha, 4 \alpha-$ endoperoxide 397. ${ }^{232}$ One allohimachalane peroxide 398 has been obtained from Illicium tsangii. ${ }^{23}$ The extract of the aerial parts of Artemisia diffusa contains tehranolide 399, a new type of sesquiterpene lactones with an endoperoxide group. ${ }^{234}$ Successful biomimetic syntheses of the litseaverticillol family of sesquiterpenes have been achieved, using singlet oxygen chemistry. ${ }^{235}$ In this work, the structure of the previously reported litseaverticillol $\mathrm{E}^{236}$ has been revised to $\mathbf{4 0 0}$.

Artemisinin, the well-known antimalarial agent, has been the focus of continuing study. Its antimalarial activity, structural modification, structure-activity relationships, mode of actions, and use in therapy have been well reviewed. ${ }^{237-240}$

3.3 Diterpenes: A dolabellane diterpene derivative 401 with the naturally rare peroxy function was identified as a component of the aerial parts of Cleome droserifolia, ${ }^{241}$ and additional related peroxide $\mathbf{4 0 2}$ was found from Aglaia odorata. $^{242}$ Jatropha integerrima provided a rhamnofolane isolation of okundoperoxide<smiles>CC1(C)CC[C@@H](O)[C@]23COCC(O)C(C2)OC[C@]13C</smiles><smiles>CC1(C)CC=C[C@@]2(C)OOC[C@]12CCO</smiles><smiles>CC1(C)CCC(=O)[C@@]2(C)OO[C@@]13C[C@H]2CC3(C)O</smiles>

365

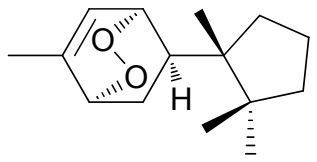

371<smiles></smiles>

$366 \mathrm{R}=\alpha \mathrm{CH}_{3}$

$367 \mathrm{R}=\mathrm{\beta CH}_{3}$

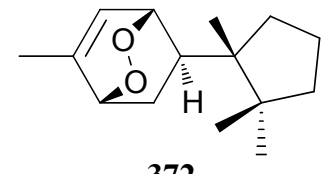

372<smiles>CC(=O)OC12C=CC([C@H]3CC[C@@H](Br)C(C)(C)C3)(CC1)OC2</smiles>

endoperoxide 2-epicaniojane 403, whose structure was confirmed by X-ray diffraction analysis. ${ }^{243}$

A clerodane peroxide, 15(16)-peroxy-3,13-clerodadien-18oic acid 404, was isolated from the Taiwanese liverwort Schistochila acuminata, ${ }^{244}$ and the structurally related $2 \beta$ hydroperoxykolavelool $\mathbf{4 0 5}$ was reported from Aristolochia chamissonis. ${ }^{24}$ The plant Casearia arguta afforded further members of the series, argutins F-H 406-408. ${ }^{246}$

The aerial parts of Aster oharai contained two labdane peroxides 409 and 410, of which compound 409 showed moderate cytotoxicity against several human tumor cell lines with $\mathrm{ED}_{50}$ values ranging from 1.1 to $7.7 \mu \mathrm{g} / \mathrm{mL}{ }^{247}$ A different species of Aster, A. spathulifofius, provided further related $7 \alpha-$ hydroperoxymanool $\mathbf{4 1 1}$ that showed moderate cytotoxicity against human cancer cells. ${ }^{179}$ Other compounds of this type included (8S)-hydroperoxy-(13S)-hydroxy-9(11),14labdadiene 412 from Jungermannia infuscua, ${ }^{210}$ ent-12,15dioxo-3,4-seco-4,8,13-labdatrien-3-oic acid 413 and ent12,15-dioxo-8,13-labdadien-3 $\alpha$-ol $\mathbf{4 1 4}$ from Croton stipuliformis, ${ }^{248}$ and $8 \alpha$-hydroxy-13-hydroperoxylabd-14,17-dien19,16:23,6 $\alpha$-diolide $\mathbf{4 1 5}$ from Salvia sahendica. ${ }^{249}$ The absolute stereochemistry of compound $\mathbf{4 1 4}$ was determined by application of Mosher's method. 


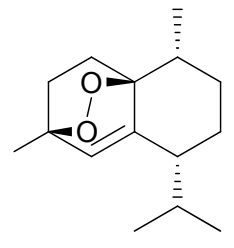

376<smiles>CC1=C[C@@]23O[C@@](O)(CC1=O)C[C@@H](C)[C@@H]2[C@@H](C(C)C)[C@@H]3O</smiles>

381<smiles>CC(C)C1=C2[C@H](O)C(C)CC[C@]2(C)CC[C@H]1C</smiles>

377<smiles>CC1C=C2OC(C)CCC23C(=C1)C(C(C)C)CCC3C</smiles>

378

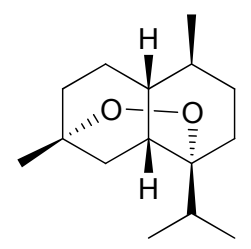

379<smiles>CC(C)C1OO[C@@]2(C)CC[C@H]3[C@@H](C)CC[C@]13C2</smiles>

380<smiles>CC(C(=O)O)[C@H]1CC[C@H]2CC[C@@](C)(O)C=C2[C@H]1C</smiles>

382<smiles>C=C1CC[C@H]2CCC[C@@H]3C(C)C(=O)OO[C@H]1[C@H]32</smiles>

383<smiles>CC1=C[C@H]2C3=C(C)COO[C@@]3(O)C[C@H](C)[C@H]2CC1=O</smiles>

384<smiles>CO[C@H]1C[C@@H](O)C2=CC(=O)C(C(C)(C)O)=CC2(C)C1C</smiles>

385<smiles>C[C@H]1[C@@H](O)CCC2=CC(=O)C(C(C)(C)O)=C[C@]21C</smiles>

389<smiles>CC(C)(O)/C=C/CC1(C)C2CCC1(C)CC2</smiles>

393<smiles>C=C1C(=O)O[C@H]2C[C@H](C)[C@]34CCC(C)(OO3)O[C@H]4C[C@H]12</smiles>

397<smiles>CC1CCC[C@H](C)[C@]12C=C1C(C)(C)OO[C@]1(O)C[C@H]2C</smiles>

386<smiles>C=C1C(=O)OCC1/C=C/C(C)(O)CC1CC(C)C(=O)O1</smiles>

390<smiles>C=C(C)[C@@H](O)CCC1(C)C2CC3C(C)C4CC1C34C2</smiles>

394

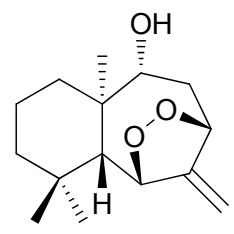

398<smiles>CC1CCCC2=CC(=O)C(C(C)(C)O)=CC21C</smiles>

387<smiles>C=C(CC1CC(C)C(=O)O1)C(O)CC1COC(=O)C1=C</smiles>

391<smiles>C=C(C)[C@@H](O)CCC1(C)C2CC3C(C)C(C2)C31C</smiles>

395<smiles>C[C@H]1C(=O)O[C@@H]2OO[C@]3(O)C[C@]4(CC[C@@H](O)[C@]4(C)C[C@@H]21)O3</smiles>

399<smiles>C[C@@H]1CC=CC23CC[C@H](COO2)C[C@@]13C</smiles>

388

The leaves of Viburnum awabuki afforded two vibsane hydroperoxides vibsanin K 416 and 18-O-methylvibsanin K 417 as well as their corresponding C-5 epimers 418 and 419, ${ }^{250,251}$ of which vibsanin $\mathrm{K}$ exhibited significant cytotoxicity against human gastric (NUGC) and oral

\section{并 Springer}


<smiles>C=C(O)C(O)CCC1=CC(O)C(C)(C)C(C(C)(C)OC(=O)CC(C)(C)CC(=O)OC)CC1C(C)(C)OC(C)=O</smiles>

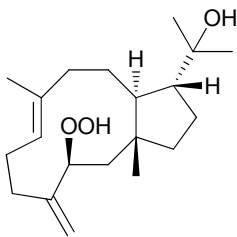

402

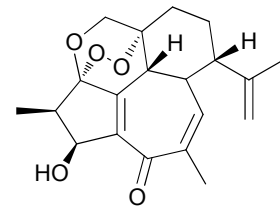

403

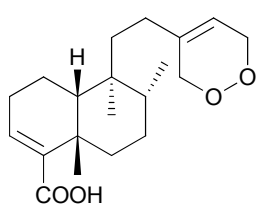

404<smiles>C=C1[C@H]2CC[C@@]3(C)C(C)=C[C@@H](O)C[C@H]3[C@@]2(C)CC[C@]1(C)O</smiles>

405

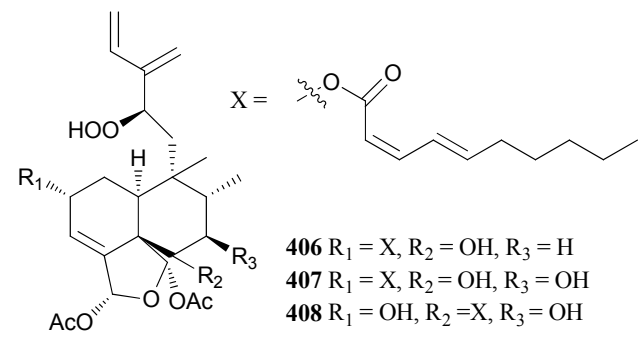

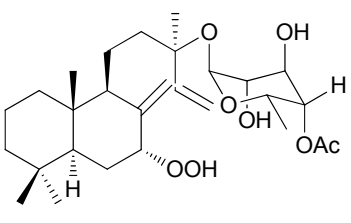

409

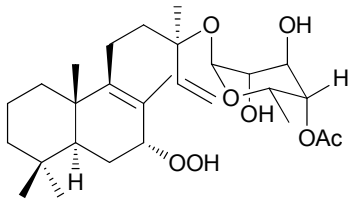

410<smiles>C=C1C(O)CC2C(C)CCCC2(C)C1CC[C@H](C)O</smiles>
411<smiles>C=CC1(O)CC=C2C3(C)CCCC(C)C3CCC2(O)C1(C)O</smiles>

412<smiles>C=C1CC[C@H]2C(=CCOO[C@H]2C)C[C@@H]1CC[C@H](C)O</smiles>

413<smiles>C=C(C)[C@H]1CCC(=C)[C@@H](CCC(=O)O)[C@@H]1CCC(=O)O</smiles>

414

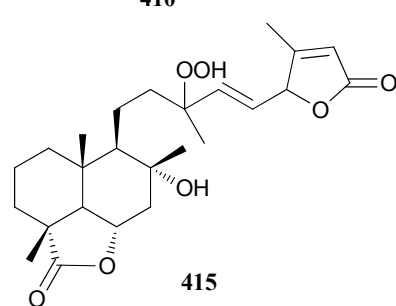

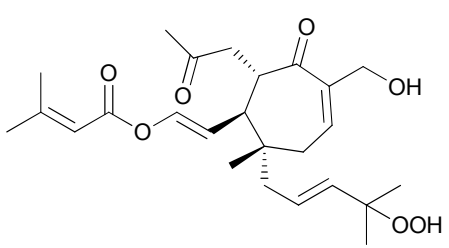

416

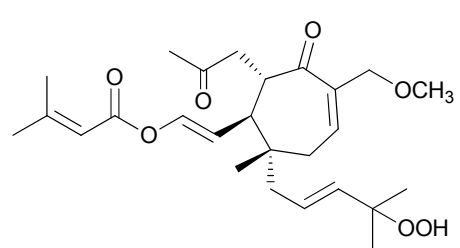

417

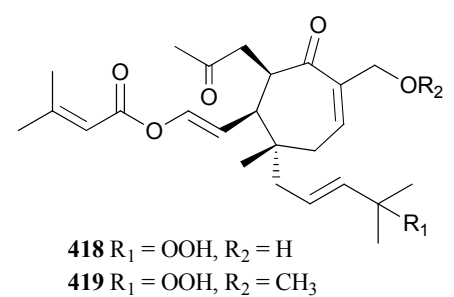

$\begin{aligned} 418 \mathrm{R}_{1} & =\mathrm{OOH}, \mathrm{R}_{2}=\mathrm{H} \\ 419 \mathrm{R}_{1} & =\mathrm{OOH}, \mathrm{R}_{2}=\mathrm{CH}_{3}\end{aligned}$

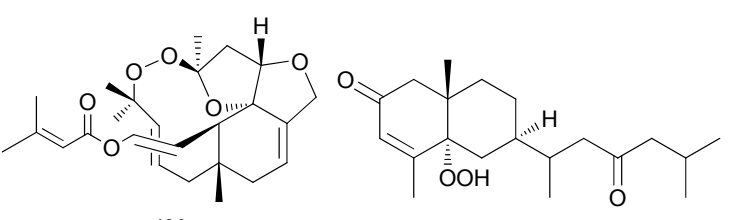

420
421<smiles>CC(=O)OOC/C=C(\C)CCCC(C)CCCC(C)CCCC(C)C</smiles>

422

leucoperoxyterpene $\mathbf{4 2 3}$ with good antibacterial activity has been isolated from aerial parts of the medicinal plant Leucosceptrum canum. ${ }^{255}$

Jungermatrobrunin A 424, which was obtained from the liverwort Jungermannia atrobrunnea, has an unusual rearrangedent-kaurene skeleton with a peroxide bridge. Its relative configuration was further supported by a single-crystal X-ray crystallographic analysis. ${ }^{256}$ A phytochemical investigation on the stems of Annona squamosa led to the isolation of additional two ent-Kaurane hydroperoxides, annosquamosins F $\mathbf{4 2 5}$ and G $\mathbf{4 2 6}{ }^{257}$

The leaves of Croton steenkampianus provided a novel diterpenoid steenkrotin B 427, which possess a new carbon skeleton that may be derived from the daphnanetype by an $8(9 \rightarrow 10)$-abeo rearrangement. ${ }^{258}$ A rare 3,4-seco-cleistanthane hydroperoxide designated as trigonochinene $\mathrm{C} \mathbf{4 2 8}$ with antimicrobial activity was isolated from the aerial parts of Trigonostemon chinensis. ${ }^{259}$
Nine jatrophane hydroperoxides, amygdaloidins $\mathrm{C} \mathbf{4 2 9}$ and E-L 430-437, have been isolated from the wood spurge, Euphorbia amygdaloides. ${ }^{260}$ A methanol extract of Anisomeles indica afforded two cembrane hydroperoxides 4-methylene$5 \beta$-hydroperoxyovatodiolide $\mathbf{4 3 8}$ and $4 \alpha$-Hydroperoxy-5enovatodiolide 439 , of which 439 showed inhibitory effects on antiplatelet aggregation induced by thrombin. ${ }^{261}$

Two abietane endoperoxides $\mathbf{4 4 0}$ and $\mathbf{4 4 1}$ were isolated as the corresponding acetate derivatives from the cones of Cedrus atlantica. $^{262}$ The aerial parts of Illicium angustisepalum contained four more abietane diterpenes, angustanoic acids B-D 442-444 and I 445. ${ }^{263}$ Investigation of the leaves and twigs of Callicarpa longissima resulted in the isolation of a 3,4-seco-abietane peroxide named callilongisins A 446 with significant anti-inflammatory effect, whose structure was further confirmed by X-ray crystallographic analysis. ${ }^{264}$ Three diterpenic acids $\mathbf{4 4 7 - 4 4 9}$ were isolated as their methyl ester derivatives from the leaves of Juniperus thurifera and 


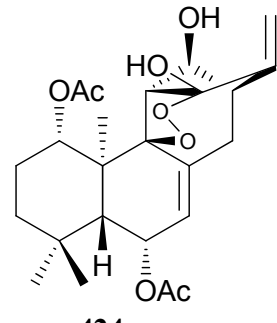

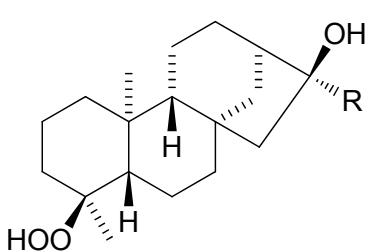

$425 \mathrm{R}=\mathrm{CH}_{2} \mathrm{OCOCH}_{3}$ $426 \mathrm{R}=\mathrm{CH}_{2} \mathrm{OH}$

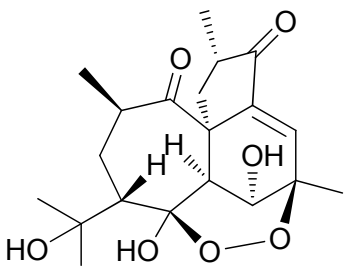

427<smiles>C=CC1=C(C)C(=O)C=C2[C@@H]1CC[C@H](C(=C)C)[C@]2(O)CCC(C)=O</smiles>

428

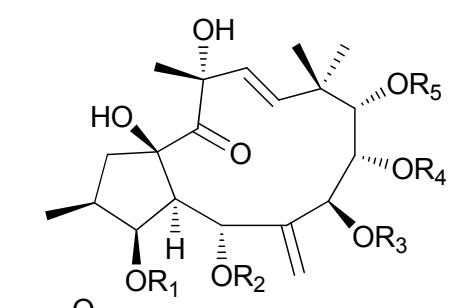

$429 \mathrm{R}_{1}=$ Hydrp, $\mathrm{R}_{2}=\mathrm{H}, \mathrm{R}_{3}=$ Ang, $\mathrm{R}_{4}=\mathrm{Ac}, \mathrm{R}_{5}=\mathrm{Nic}$ $430 \mathrm{R}_{1}=$ Ang, $\mathrm{R}_{2}=\mathrm{H}, \mathrm{R}_{3}=$ Hydrp, $\mathrm{R}_{4}=\mathrm{Ac}, \mathrm{R}_{5}=\mathrm{Ac}$ $431 \mathrm{R}_{1}=$ Ang, $\mathrm{R}_{2}=$ Ac, $\mathrm{R}_{3}=\mathrm{H}, \mathrm{R}_{4}=$ Hydrp, $\mathrm{R}_{5}=\mathrm{Ac}$ $432 \mathrm{R}_{1}=$ Hydrp, $\mathrm{R}_{2}=$ Ac, $\mathrm{R}_{3}=\mathrm{H}, \mathrm{R}_{4}=$ Ang, $\mathrm{R}_{5}=\mathrm{Ac}$<smiles>C/C=C(/C)C=O</smiles>
$433 \mathrm{R}_{1}=$ Ac, $\mathrm{R}_{2}=$ Hydrp, $\mathrm{R}_{3}=\mathrm{H}, \mathrm{R}_{4}=$ Ang, $\mathrm{R}_{5}=$ Ac $434 \mathrm{R}_{1}=$ Hydrp, $\mathrm{R}_{2}=\mathrm{Ac}, \mathrm{R}_{3}=$ Ang, $\mathrm{R}_{4}=\mathrm{H}, \mathrm{R}_{5}=\mathrm{Ac}$

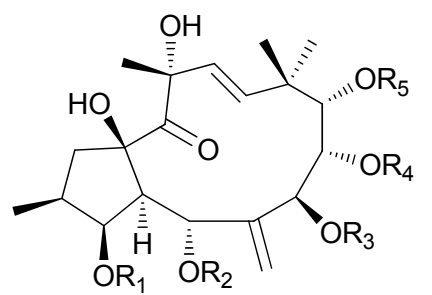

437

Hydrp $=$

$\mathrm{O}$

$435 \mathrm{R}_{1}=\mathrm{Ac}, \mathrm{R}_{2}=$ Hydrp, $\mathrm{R}_{3}=$ Ang, $\mathrm{R}_{4}=\mathrm{H}, \mathrm{R}_{5}=\mathrm{Ac}$

$436 \mathrm{R}_{1}=$ Ang, $\mathrm{R}_{2}=$ Ac, $\mathrm{R}_{3}=$ Hydrp, $\mathrm{R}_{4}=\mathrm{H}, \mathrm{R}_{5}=\mathrm{Ac}$ 
<smiles>C=C1C[C@H](/C=C(\C)C[C@@H]2C=C(CC[C@@H](O)C(=C)CC[C@H]3C(=C)C(=O)O[C@@H]3O)C(=O)O2)OC1=O</smiles><smiles>C=C1C(=O)O[C@@H](/C=C(\C)C[C@@H]2C=C(C/C=C/C(C)(O)O)C(=O)O2)C1CCO</smiles>

438<smiles>C=C(C)C12C=C3CC[C@H]4[C@@](C)(C(=O)O)CCC[C@]4(C)C3(CC1)CO2</smiles>

442<smiles>C=C(C)[C@H]1CCC2=C[C@@]3(C(C)C)CC[C@]2(O3)[C@@]1(C)CCC(=O)O</smiles>

446<smiles>CC(C)(O)[C@@]12C=C3CC[C@H]4[C@@](C)(C(=O)O)CCC[C@]4(C)[C@]3(CC1)C2</smiles>

443

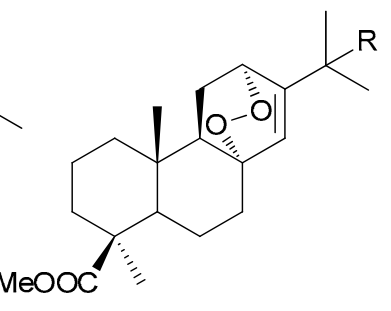

$447 \mathrm{R}=\mathrm{OOH}$

$448 \mathrm{R}=\mathrm{OH}$<smiles>CC(C)C1=C[C@]2(O)OO[C@H]3CC4=C(COC4=O)[C@@H]4CCC(=C2C1=O)[C@@]34C</smiles>

451<smiles>CC(C)c1cc2c(cc1O)[C@]1(C)CCCC(C)(C)C1C(=O)C2</smiles>

452<smiles>C[C@H](CO)C1=C[C@@]2(O)CC[C@H]3C(C)(C)CCC[C@]3(C)C2=CC1=O</smiles>

453

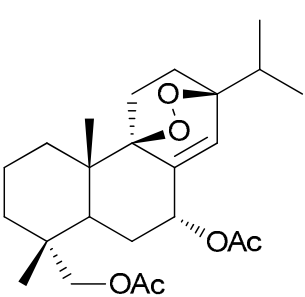

441<smiles>C=C(C)C1=CC(=O)[C@H]2C[C@H]3[C@@](C)(C(=O)O)CCC[C@]3(C)[C@@]2(O)CC1</smiles>

444

445

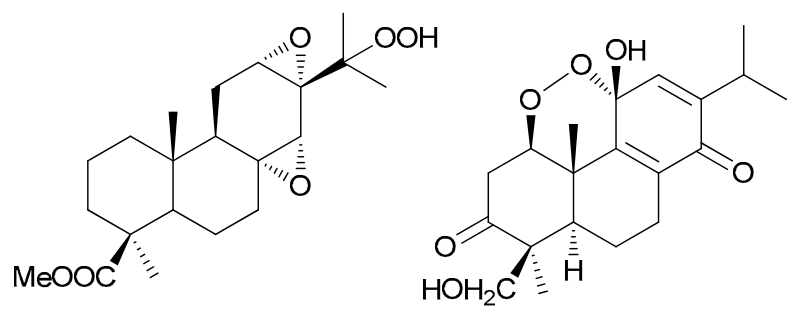

450<smiles>CC(=O)OCC(O)[C@]1(C)CCC2C(=CCC3C(C)(C)[C@@H](OC4CCCCC4)CC[C@@]23C)[C@@H]1O</smiles>

454

4 $\alpha$-hydroperoxy-6-O-acetylnimbandiol 514. $^{301}$ The absolute configuration of known longilene peroxide ${ }^{302}$, isolated from the wood of Eurycoma longifolia, has been established by total synthesis. $^{303}$

Two euphane hydroperoxides, meliasenins A 515 and C 516, were isolated from the stem bark of Melia toosendan. ${ }^{304}$ Further members of this type, meliasenins I-O 517-523, were obtained from the fruits of the same plant. The relative configuration of $\mathbf{5 1 7}$ was further confirmed by single-crystal X-ray diffraction analysis. ${ }^{305}$ Another two species of this genus, $M$. dubia and M. azedarach, contained meliastatin 524 and 25hydroperoxytirucalla-7,23(24)-diene-3,6-dion-21,16-olide 525, respectively. Meliastatin exhibited significant inhibition of the P388 cancer cell line. ${ }^{306,307}$ The roots of Euphorbia micractina
A peroxy-multiflorane triterpene ester 513 has been isolated from the processed seeds of Trichosanthes kirilowii. ${ }^{300}$ The plant Azadirachta indica contained a tetranortriterpenoid,

\section{望 Springer}




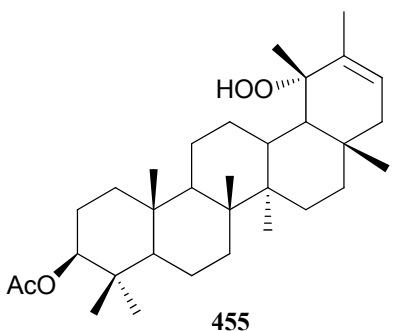

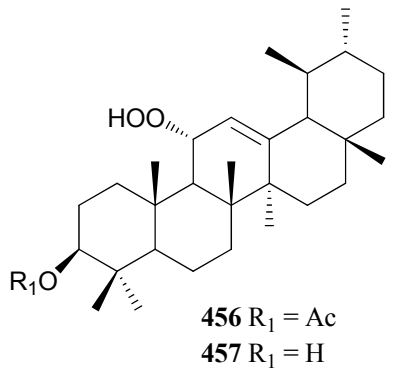

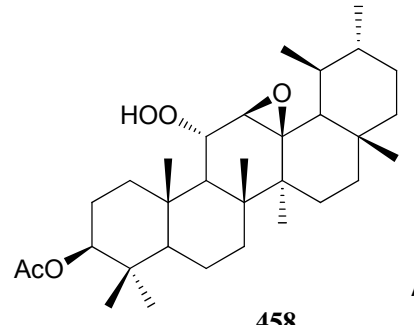

458

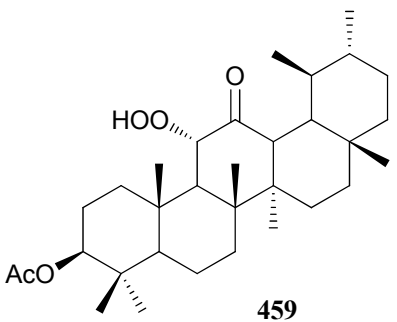

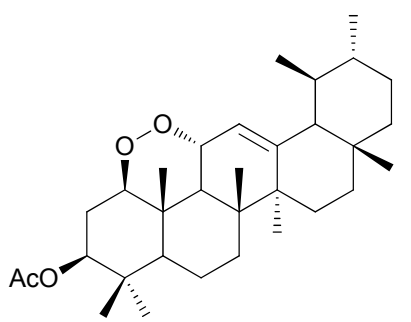

460

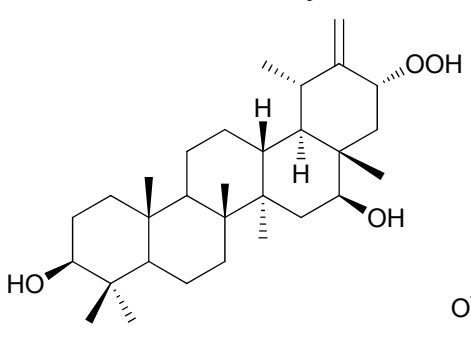

461

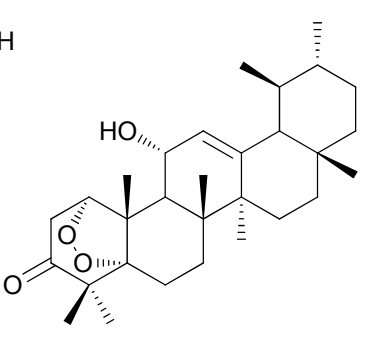

462

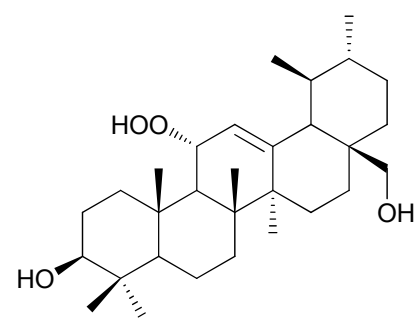

463

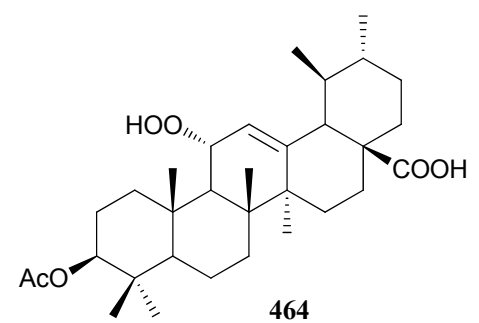

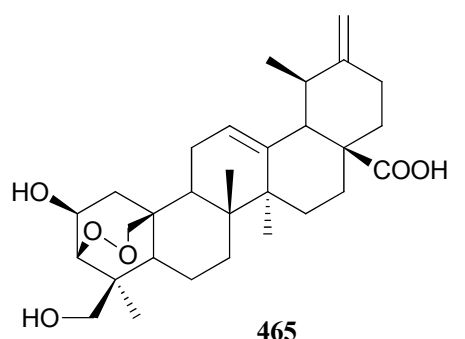

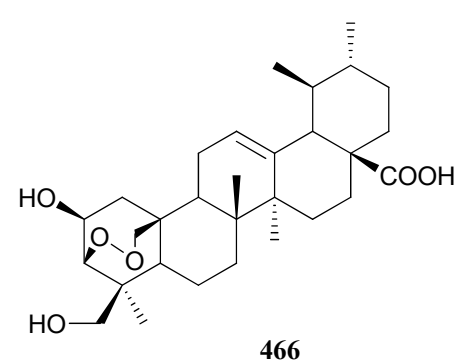

afforded further euphane/tirucallane derivatives 526-530. ${ }^{308}$

Three 3(4),9(10)-disecocycloartane peroxy triterpene lactones, pseudolarolides $Q_{2}$ 531, $T_{1}$ 532, and $T_{2}$ 533, were discovered from the seeds of Pseudolarix kaempferi. ${ }^{309}$ The leaves of the same species contained three more triterpene peroxides, pseudolarolides Q-S 534-536. The stereochemical structures of these compounds were confirmed by singlecrystal X-ray analyses. ${ }^{310}$ One triterpene dilactones with a rare rearranged pentacyclic skeleton, longipedlactone $\mathrm{K}$ 537, was found from the stems of Kadsura ananosma. ${ }^{311}$ A cytotoxic triterpenoid schinalactone A 538, an endoperoxide with an unusual contracted ring $\mathrm{A}$, has been isolated from the roots and stems of Schisandra sphenanthera, which showed significant cytotoxicity against PANC-1 cell lines with a $\mathrm{IC}_{50}$ value of $5.9 \mu \mathrm{M}^{312}$ The structure of a non-peroxidic metabolite, named podocarpaside $\mathrm{E},{ }^{313}$ has been revised to $\mathbf{5 3 9}$ on the basis of an X-ray analysis. ${ }^{314}$

3.5 Others: The structurally novel antiproliferative metabolite designated hexacyclinol $\mathbf{5 4 0}$ was first described by Gräfe and co-workers from basidiospores collected from Panus rudis growing on dead betula woods in Siberia. ${ }^{315}$ The structure of hexacyclinol was subsequently revised, and an alternative structure 541 was confirmed via total synthesis. In addition, an X-ray crystal structure was obtained, providing unequivocal structural confirmation. ${ }^{316,317}$ The first peroxide among the prenylated benzophenones, plukenetione C 542, was reported from the fruits of Clusia plukenetii. ${ }^{318}$ Continuing

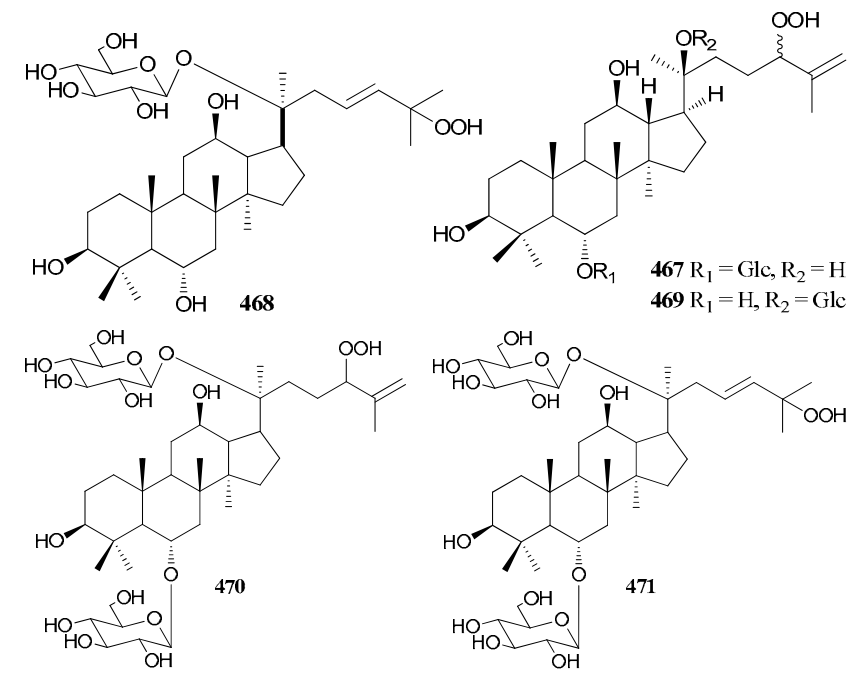

investigations of the plant yielded two further related prenylated benzophenone derivatives, 33-hydroperoxyisoplukenetione C $\mathbf{5 4 3}$ and 15,16-dihydro-16-hydroperoxyplukenetione F 544. ${ }^{319}$ Another two compounds of this type, peroxysampsones A 545 and B 546, were isolated from the roots of the Chinese medicinal plant Hypericum sampsonii, of which peroxysampsone A showed comparable activity with norfloxacin against a NorA over-expressing multidrugresistant (MDR) strain of Staphylococcus aureus SA-1199B. ${ }^{320}$ 

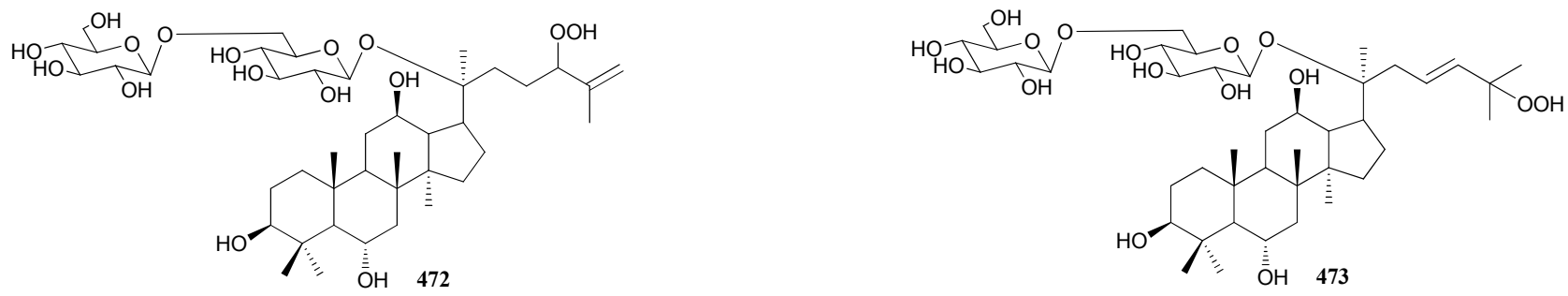

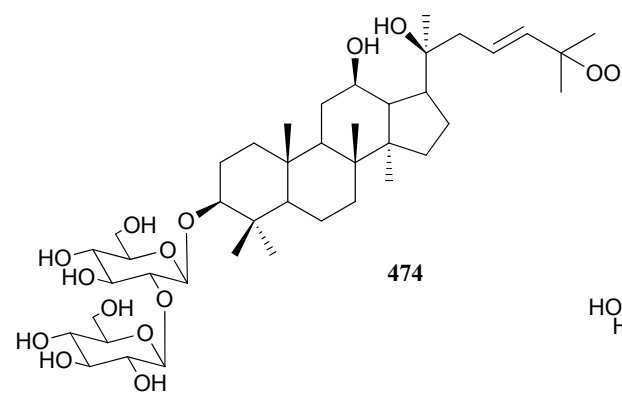

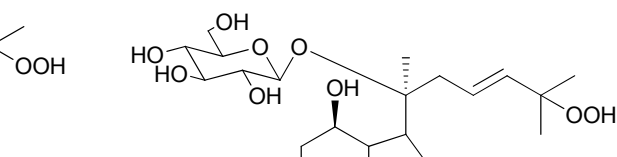
$\mathrm{OH}$

473<smiles>CC(C)C(C)[C@H](C)C/C=C/C(C)(C)O</smiles><smiles>CC1CCC2C(CCC(OC(O)C(O)C(O)C(O)C(O)C(C)C)C2(C)C)C1</smiles>
$\mathrm{OH}$

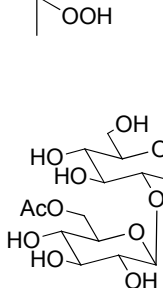<smiles>C1COC2COC(C1)O2</smiles>

475

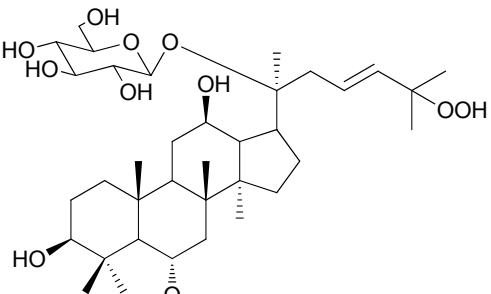

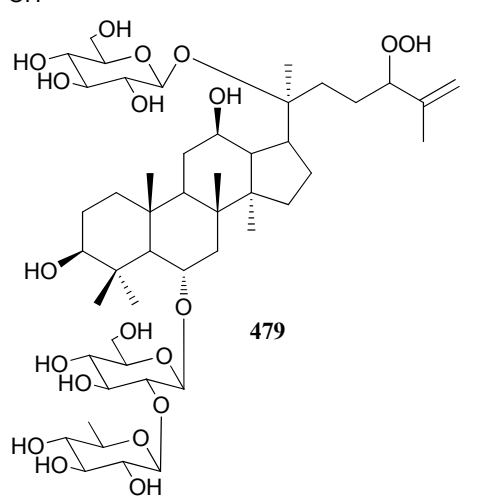

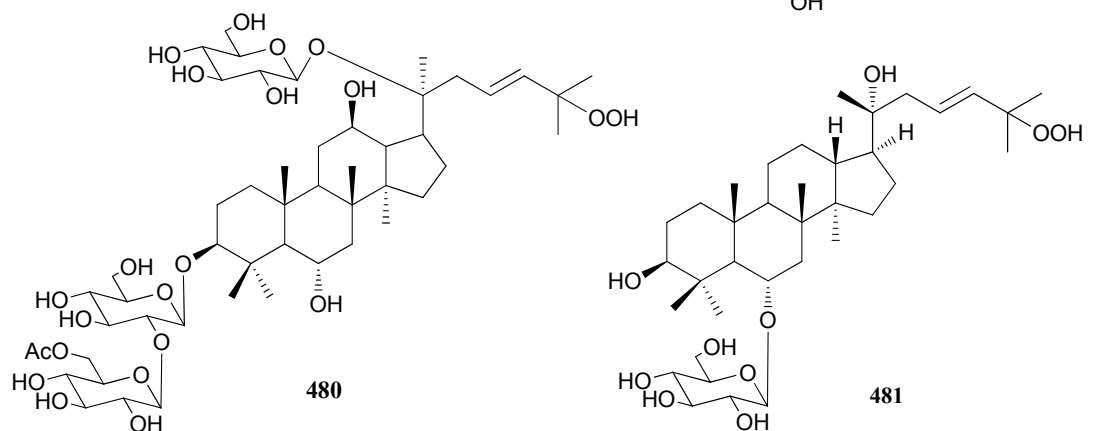

A neurofibromatosis type 1 (NF1)-based bioassay-guided phytochemical investigation on Zanthoxylum armatum collected in Nepal led to the isolation of two isomeric timuramides A 547 and B 548, both of which can inhibite growth of $N f 1$-defective tumor cell line at noncytotoxic concentrations. ${ }^{321}$ One antibacterial acylphloroglucinol, olympicin D 549, was isolated and characterized from the aerial parts of Hypericum olympicum. ${ }^{322}$ A hydroperoxyquinolone alkaloid, glycopentaphyllone 550, was reported from the fruits of Glycosmis pentaphylla, whose absolute configuration was established by applying Mosher's method. ${ }^{32}$

Walsuronoid A $\mathbf{5 5 1}$ was the first limonoid with a peroxide linkage from Walsura robusta. The structure of walsuronoid A was also confirmed by X-ray analysis. ${ }^{324}$ The stems of Khaya anthotheca afforded one further limonoid $\mathbf{5 5 2},{ }^{325}$ and the related xylocarpin G $\mathbf{5 5 3}$ was obtained from the Chinese mangrove plant, Xylocarpus granatum. ${ }^{326}$ Additional member of the group, munronoid F 554, was discovered from Munronia unifoliolata. ${ }^{32}$

Two unprecedented spiroketal peroxides, chloropupukeanolides A $\mathbf{5 5 5}$ and B 556, were isolated from an endophytic fungus Pestalotiopsis fici, with chloropupukeanolide A showing significant anti-HIV-1 and cytotoxic effects. A possible biosynthetic pathway to chloropupukeanolides A and $\mathrm{B}$ has been proposed. ${ }^{328}$ A cytotoxic prenylated flavone, named artoindonesianin B 557, was obtained from the root of Artocarpus champeden. ${ }^{329}$ The root of Zanthoxylum zanthoxyloides provided an aromatic peroxide 558. ${ }^{330}$

A peroxy acid urticic acid $\mathbf{5 5 9}$ was discovered from the whole plant of Leucas urticifolia. ${ }^{331}$ A spiranoid withanolide 560 was obtained from the leaves of Jaborosa odonelliana. ${ }^{332}$ 
<smiles>C=C(C)[C@H](O)CCC(C)(O)C1CC[C@@H]2C1CC1C2C(O)CC2[C@]1(C)CCC1C(C)(C)[C@@H](O)CC[C@@]12C</smiles>

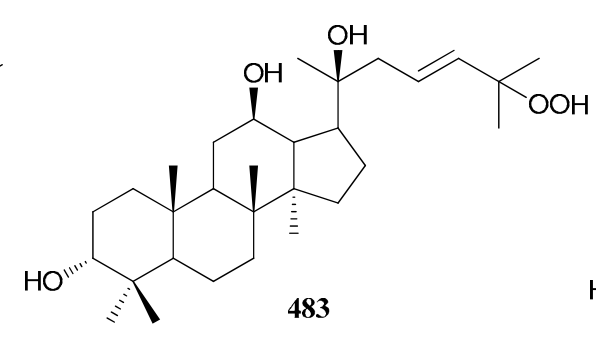<smiles>C=C(C)C(O)CCC(C)(O)C1CCC2C1C(O)C(O)C1C3(C)CC[C@@H](O)[C@@H](C)C3CC[C@]21C</smiles>

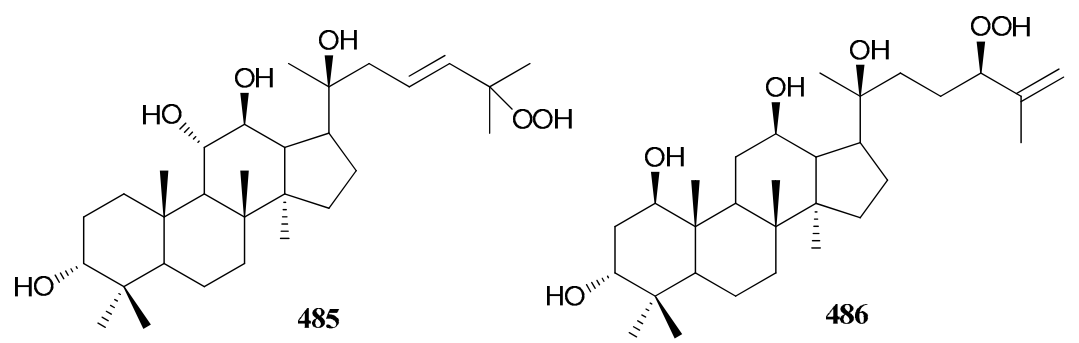

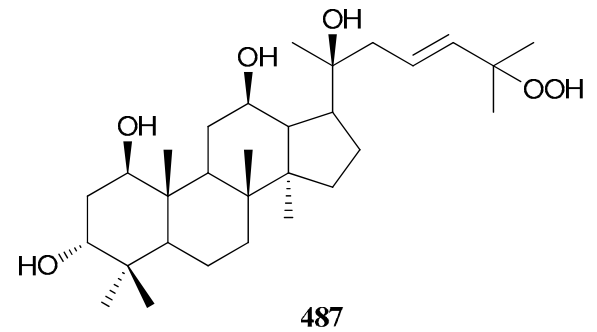

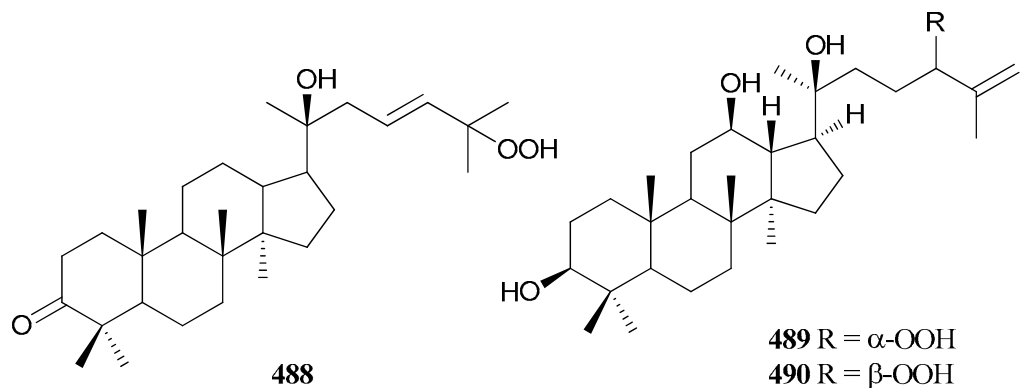<smiles>C=C(C)[C@H](O)CC[C@@H](O)C1CCC2C1CCC1C2(C)CCC2C1(C)CC[C@@H](O)C2(C)C</smiles>

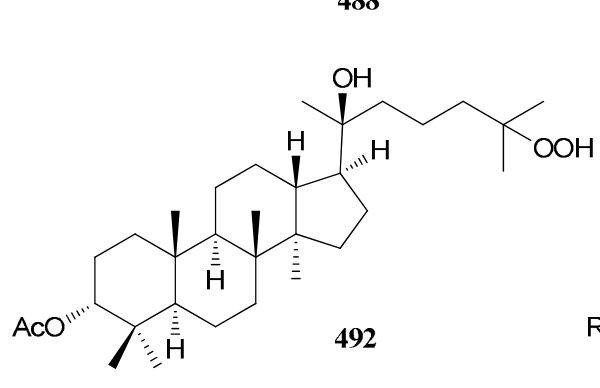

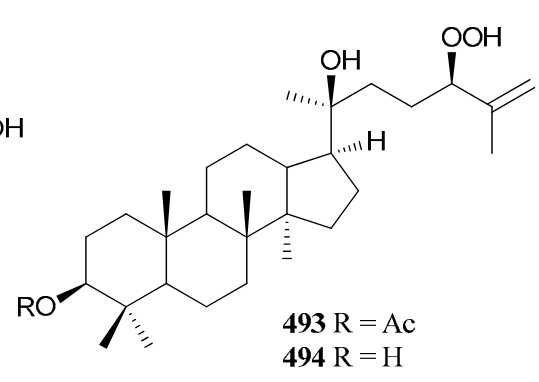

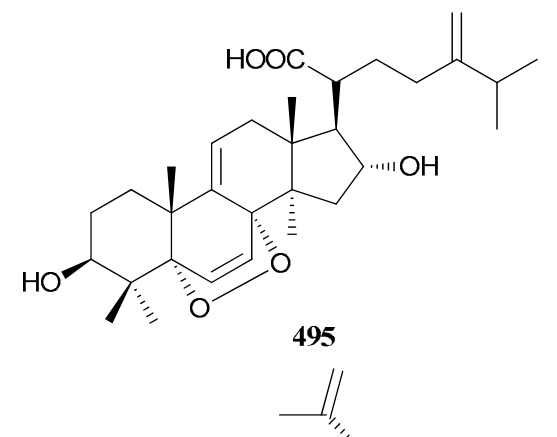

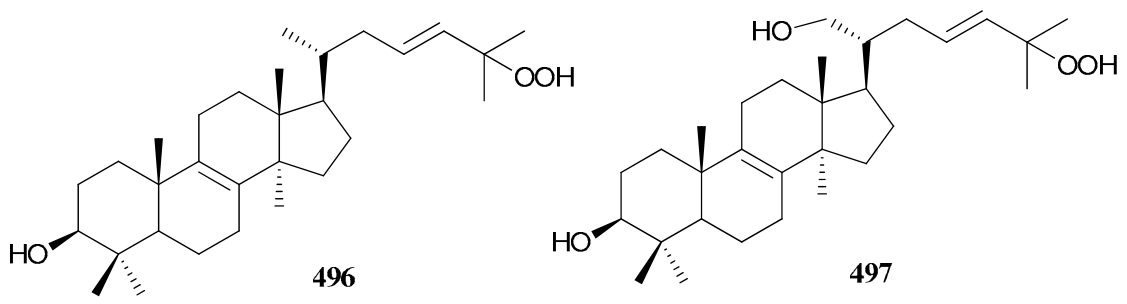

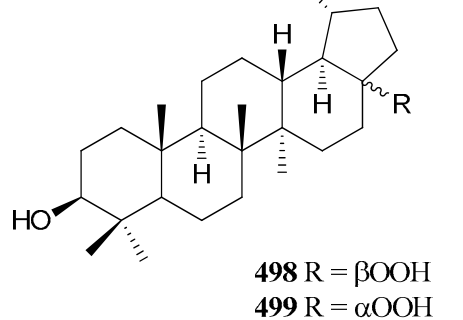

The stems of Millettia taiwaniana contained one isoflavonoid peroxide millewanin E 561. ${ }^{333}$ Brasixanthone C $\mathbf{5 6 2}$ was identified as a constituent of the stem bark of Calophyllum brasilienses collected in Brazil. ${ }^{334}$ One lignan tiegusanin M 563 was a constituent of the aerial parts of Schisandra propinqua. ${ }^{335}$ The unique neolignan mansoxetane 564, isolated from the heartwood of Mansonia gagei, is the first example of a biphenylneolignan with a dioxetane ring discovered in nature. ${ }^{336}$
Two prenylated polyketides, harrisotones C 565 and D 566 representing a rare spirocyclic skeleton, along with a cytotoxic hydroperoxypolyketide harrisonol A 567, were isolated from Harrisonia perforata. ${ }^{337}$ Two butanolides, litseadioxanins A 568 and B 569 bearing a 1,2-dioxane moiety, were obtained from the stem bark of Litsea akoensis. ${ }^{338}$

Chemical investigation of the leaves of Machilus japonica resulted in the isolation of apigenosylides A-C 570-572, which possess an unprecedented skeleton comprising the

\section{照 Springer}




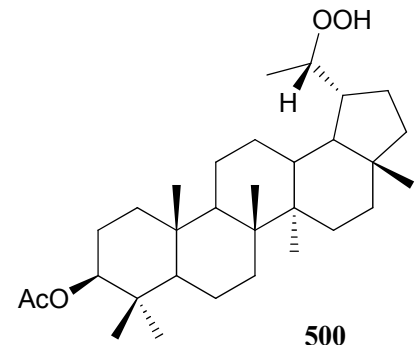

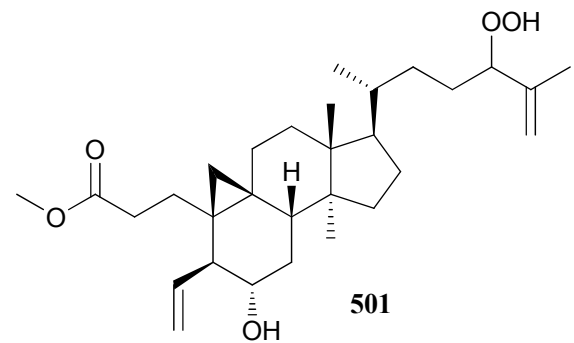

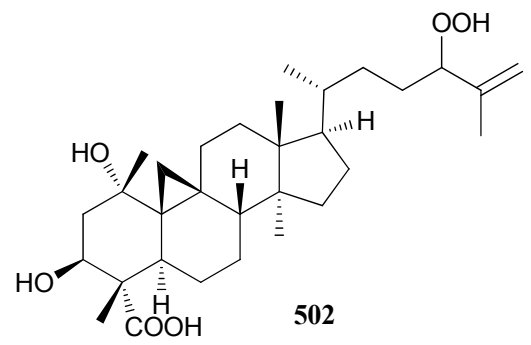

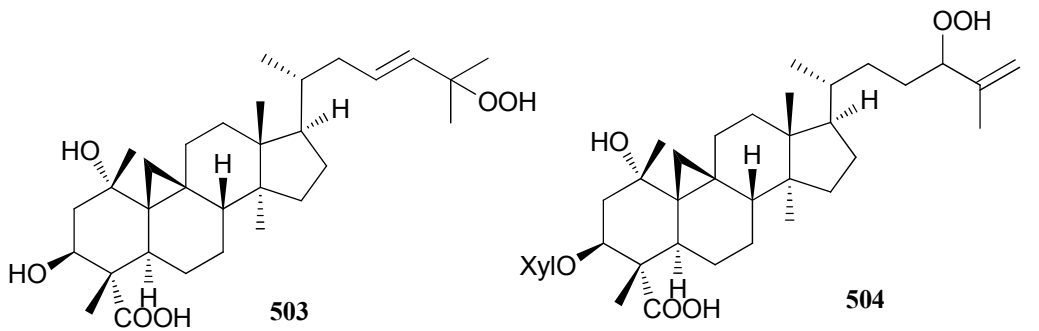

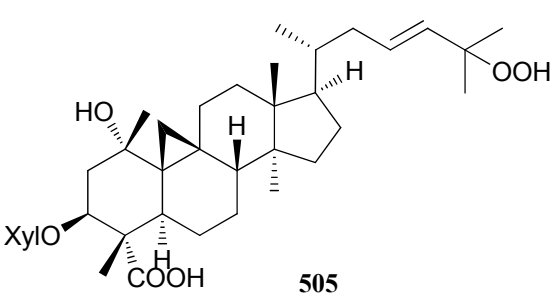

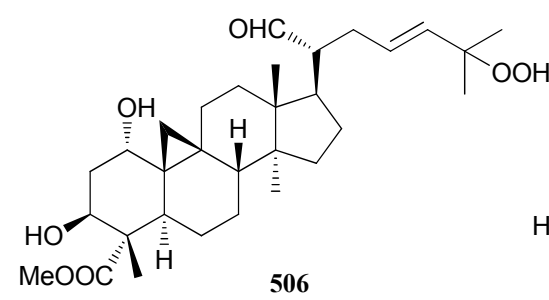

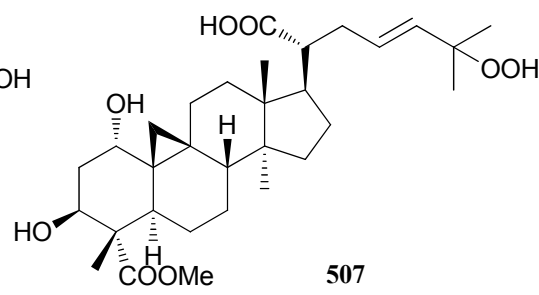

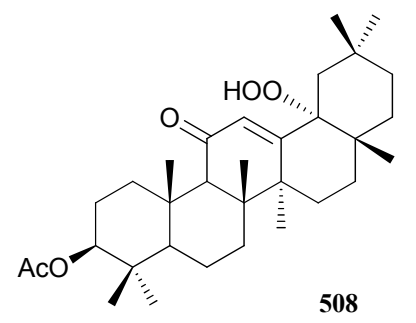

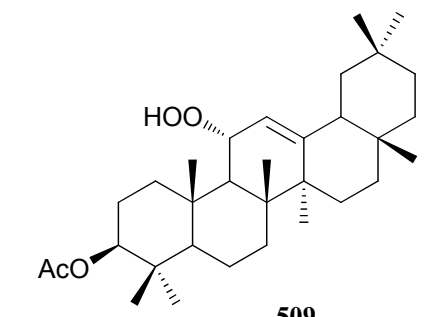

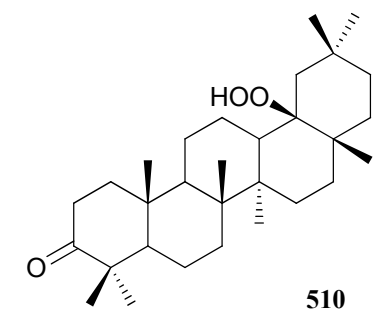

510

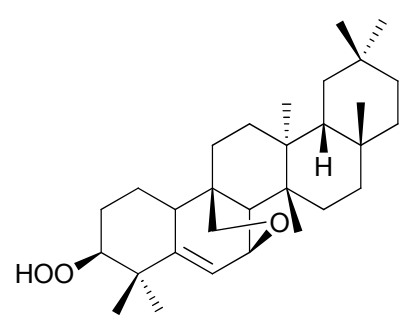

511

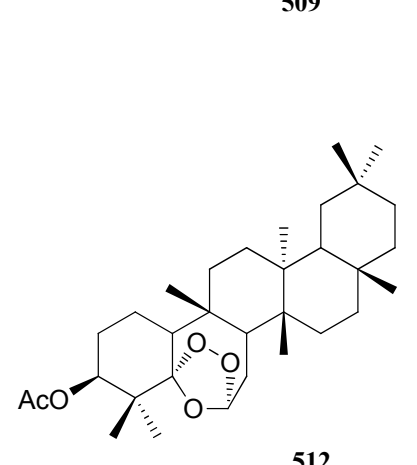

512

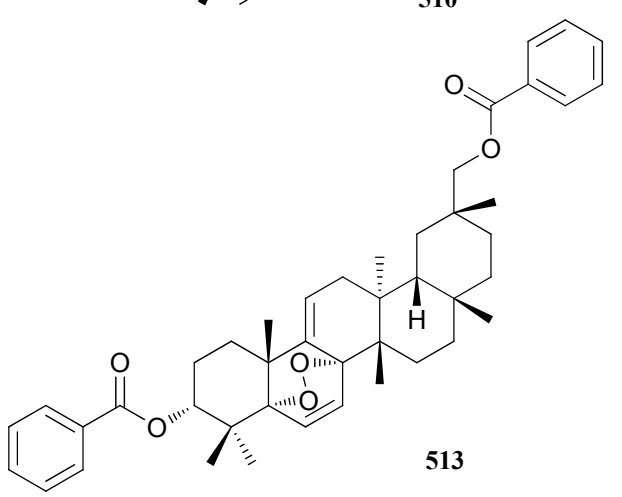<smiles>COC(=O)C[C@@H]1[C@]2(C)C3C[C@H](c4ccoc4)C[C@H]3O[C@@H](C2OC(C)=O)[C@@H]2[C@@](C)(O)C=CC(=O)[C@@]21C</smiles>

peroxide named kramecyne $\mathbf{5 7 4}$ with good anti-inflammatory activity has been isolated from Krameria cytisoides. ${ }^{341}$

Xanthoangelol E, originally obtained from the root of Angelica keiskei, ${ }^{342}$ showed the effects of xanthoangelol, on NF- $\kappa$ B activation and ET-1 gene expression in cultured porcine aortic endothelial cells. ${ }^{343}$ Two furanocoumarins, melicotriphyllins B $\mathbf{5 7 5}$ and D $\mathbf{5 7 6}$ bearing a hydroperoxy group on the geranyloxy side chain, were isolated from the

adduct of a butenolide moiety and apigenin glycoside linked via a 1,2-dioxane moiety. Apigenosylides $\mathrm{B}-\mathrm{C}$ possess moderate inhibitory activity against $\alpha$-glucosidase. ${ }^{339}$ Highthroughput natural products chemistry methods have facilitated the isolation of a beilschmiedic acid peroxide beilschmiedic acid N 573 from the leaves of a Gabonese species of Beilschmiedia, which may be an artifact of isolation formed through Diels-Alder addition of singlet oxygen. ${ }^{340}$ A cyclic

\section{然 Springer}


<smiles>[CH][C@@]12[C@@H](C[C@]3(C)C4=C[C@H](O)C5C(C)(C)C(=O)CC[C@]5(C)[C@H]4CC[C@H]31)OC(=O)[C@@H]2C/C=C/C(C)(C)O</smiles>

515

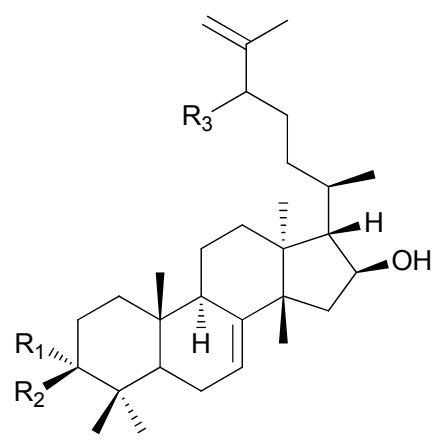

$519 \mathrm{R}_{1}=\mathrm{H}, \mathrm{R}_{2}=\mathrm{OH}, \mathrm{R}_{3}=\mathrm{OOH}$ $520 \mathrm{R}_{1}=\mathrm{O}, \mathrm{R}_{2}=\mathrm{O}, \mathrm{R}_{3}=\mathrm{OOH}$<smiles>COOC[C@H](C/C=C/C(C)(C)O)[C@H]1[C@H](O)C[C@]2(C)C3=CCC4C(C)(C)C(=O)CC[C@]4(C)[C@H]3CC[C@]12C</smiles><smiles>CC(C)(O)/C=C/C[C@H]1C(=O)O[C@@H]2C[C@]3(C)C4=CC(=O)C5C(C)(C)[C@@H](O)CC[C@]5(C)[C@H]4CC[C@]3(C)[C@@H]21</smiles>

516

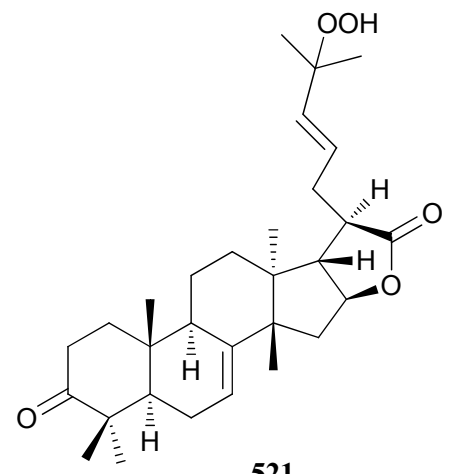

521<smiles>CC(C)(O)/C=C\C[C@H]1C(=O)O[C@@H]2C[C@]3(C)C4=CC(=O)C5C(C)(C)C(=O)CC[C@]5(C)[C@H]4CC[C@]3(C)[C@@H]21</smiles>

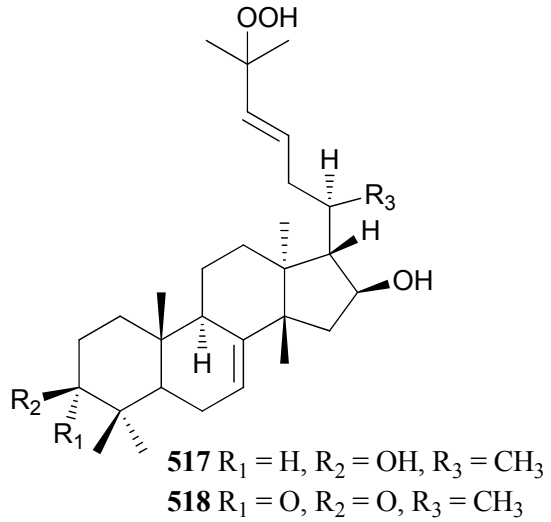<smiles>C=C(C)[C@H](O)CC[C@H]1C(=O)O[C@H]2C[C@]3(C)C4=CC[C@H]5C(C)(C)C(=O)CC[C@]5(C)[C@H]4CC[C@]3(C)[C@@]21C</smiles>

$\mathbf{5 2 2} 24 S$ 

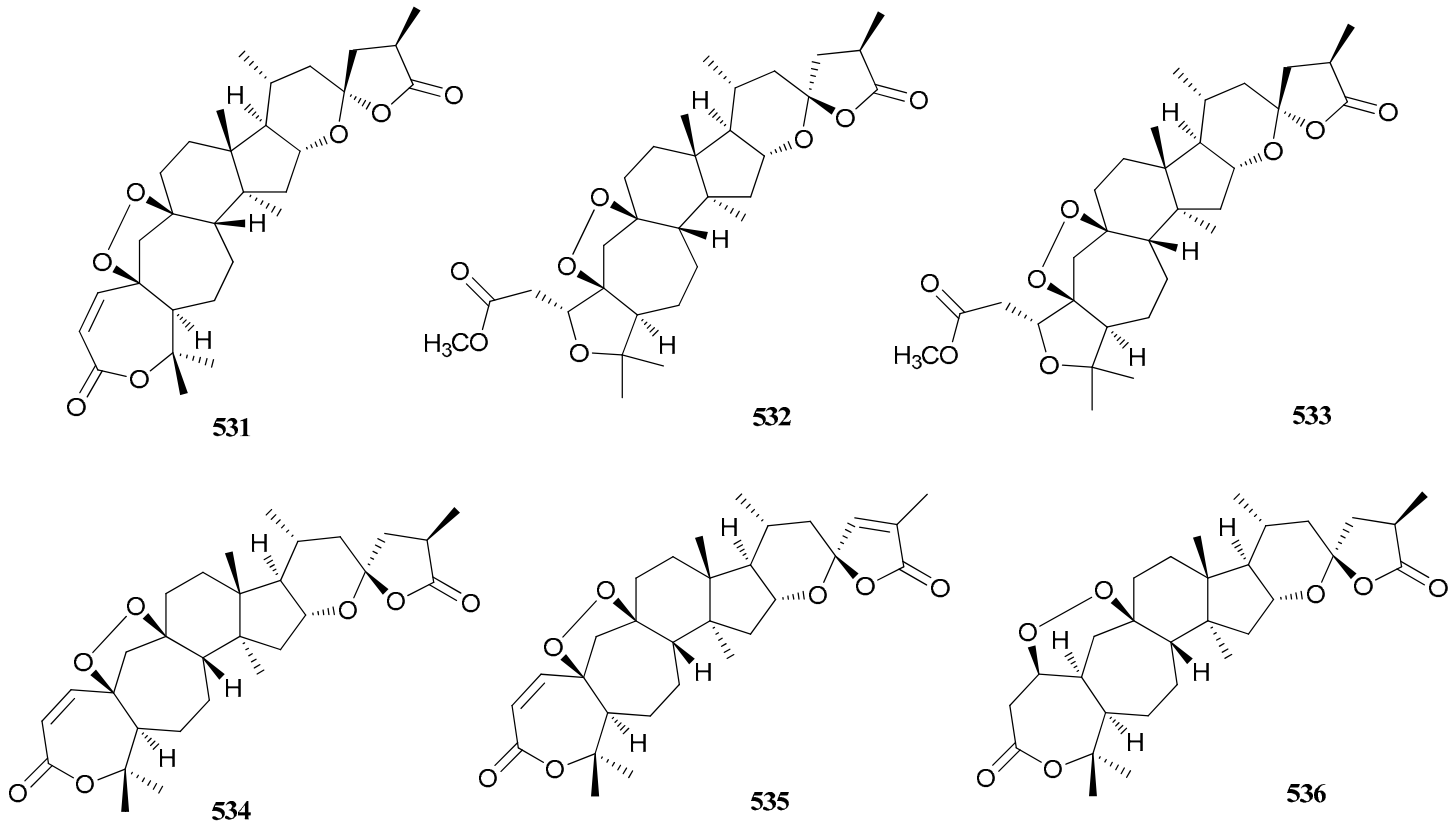

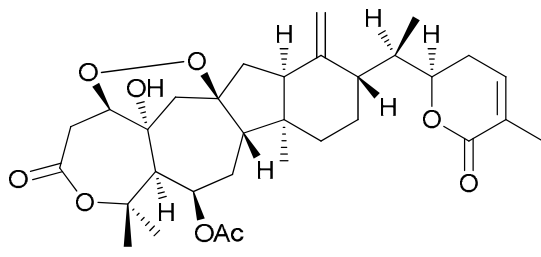

537

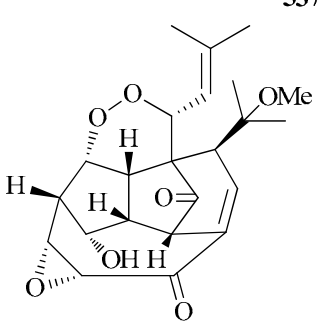

540

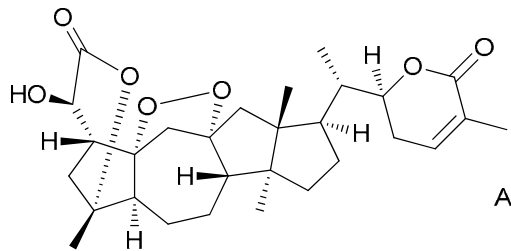

538

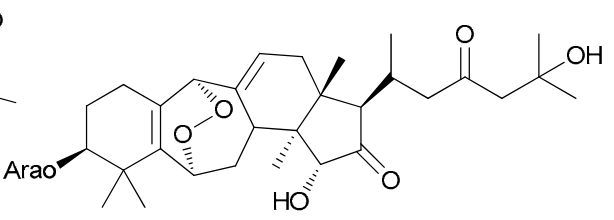

539

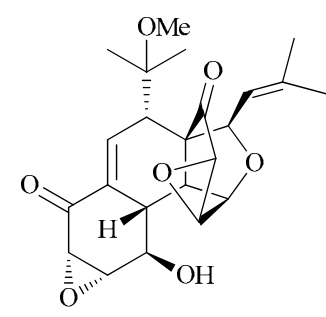

541<smiles>CC(C)=CCC12CC3CC(C(C)(C)C)(C1)C(C(=O)c1ccccc1)(C(=O)c1ccccc1)C(C(C)(C)O)(C2)OOC(C)(C)OO3</smiles>

542

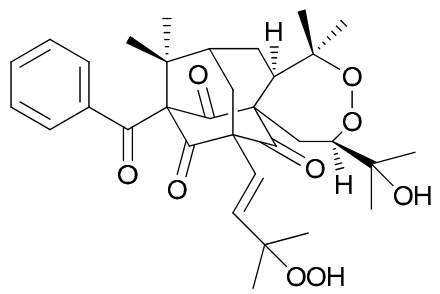

543

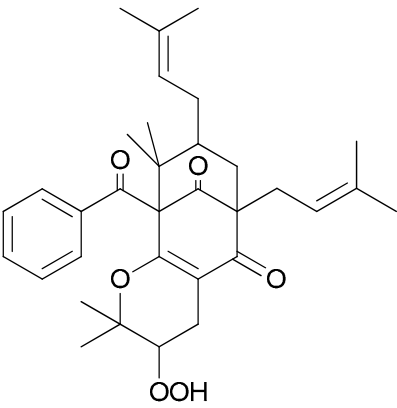

544

undescribed Streptomyces species. ${ }^{347}$ The aerial parts of the medicinal plant Clerodendrum bungei afforded additional peroxide dimer named bungein A 582. ${ }^{348}$

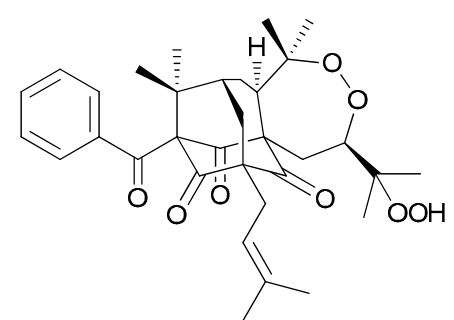

545

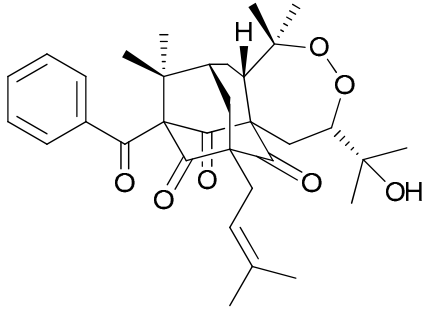

546

Clausamine G 583 containing a hydroperoxy moiety in the molecule, is the first example of the isolation of a peroxygen- 
<smiles>C[C@H]1C=C[C@@H](/C=C/CC/C=C/C(=O)NCC(C)(C)O)OO1</smiles>

547<smiles>C=C(C)[C@H](O)Cc1c(OC)c2cccc(OC)c2n(C)c1=O</smiles>

550

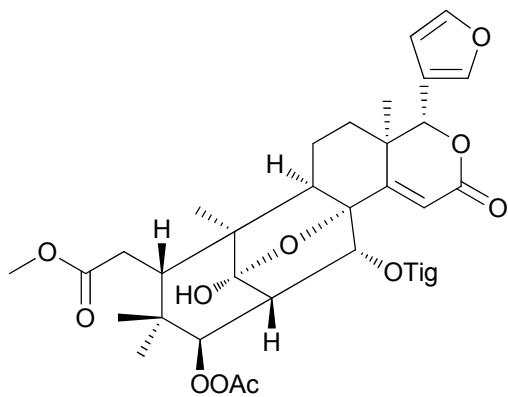

553<smiles>COc1cc2oc3c(c(=O)c2c(O)c1/C=C/C(C)C)CC(C(C)(C)O)Oc1cc(O)ccc1-3</smiles>

557<smiles>CC1C=C[C@H](/C=C/CC/C=C/C(=O)NCC(C)(C)O)OO1</smiles>

548

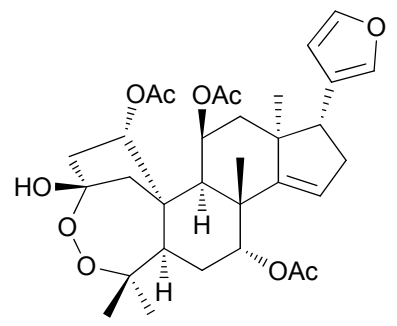

551<smiles>CC(=O)OC1C2C(C)(C)OC(=O)C=CC2(C)C2CCC3(C)C(=CC(O)C3C3COC(=O)C3)C2(C)C1OC(C)=O</smiles>

554<smiles>COc1cc(C(=O)OC2C3OOC(C(O)CCC3O)C2OC(=O)c2ccc(O)c(OC)c2)ccc1O</smiles><smiles>C=C(C)[C@H](O)CCC1=CC2Oc3cc(O)cc(O)c3C(=O)C2CC1</smiles>

549

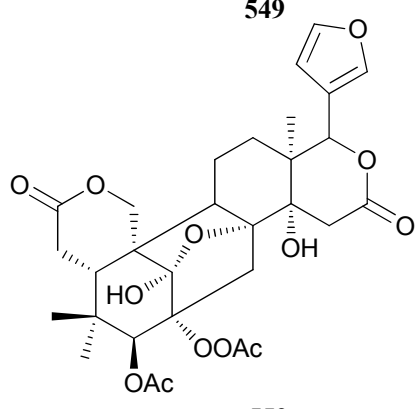

552

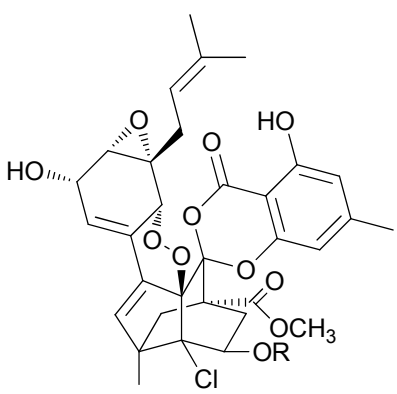

$555 \mathrm{R}=\mathrm{CH}_{3}$ $556 \mathrm{R}=\mathrm{H}$ ated carbazole alkaloid in nature. ${ }^{349}$ The leaves of Piper aduncum afforded an prenylated benzoic acid derivative $\mathbf{5 8 4}$ with antifungal activity whilst the related $\mathbf{5 8 5}$ was obtained from the aerial parts of Aster spathulifolius. The presence of a hydroperoxide group at the side chain could be directly associated to its fungitoxicity. ${ }^{179,350}$ Bioactivity-guided fractionation of the extract from Piper crassinervium afforded one prenylated hydroquinone $\mathbf{5 8 6}^{3}$

The buds of Lonicera japonica contained a novel cyclic peroxide named shuangkangsu $\mathbf{5 8 7}$ with significant antiviral activities, whose absolute stereochemistry was determined by CD analysis. $^{352}$ Echinobithiophene A 588, a peroxide bithiophene with significant antimicrobial activity, was isolated from Echinops ritro, and its structure was identified by spectral analysis including 2D NMR, and comparison of optical rotation values and chemical shifts of ${ }^{13} \mathrm{C} N M R$ between the predicted and experimental data. ${ }^{353}$ A pyrrolidone peroxide cucubalactam $\mathbf{5 8 9}$ has been reported from Cucubalus baccifer. ${ }^{354}$ A mutualist actinomycete of the southern pine beetle, Dendroctonus frontalis, produced a polyene peroxide, mycangimycin 590, with pronounced antifungal activity. Its absolute configuration was determined by chemical modification followed by the modified Mosher method. ${ }^{355}$ The stem bark of the African tree Antiaris africana afforded a cardiac glycoside africanoside 591, which effected a concentration-dependent inhibition of tumor cell growth with a mean $\mathrm{IC}_{50}$ value of $5.3 \mathrm{nM}^{356}$

\section{Steroidal Peroxides}

The ubiquitous ergosterol peroxide ${ }^{357}$ continued to be isolated from any number of sources, marine as well as terrestrial, particularly mushrooms. The diverse biological activities have been attributed to ergosterol peroxide. Ergosterol peroxide was found to be a inhibitor to the proliferation of K562, Jurkat, WM-1341, HL-60, and RPM1-8226 tumor cell lines by 10 to $40 \%$ at $10 \mu \mathrm{g} / \mathrm{mL}{ }^{358}$ Ergosterol peroxide from

\section{照 Springer}


<smiles>CCCCCCCCOC(=O)CCCC1OOC(CC/C=C/CCCC(=O)O)C1=O</smiles>

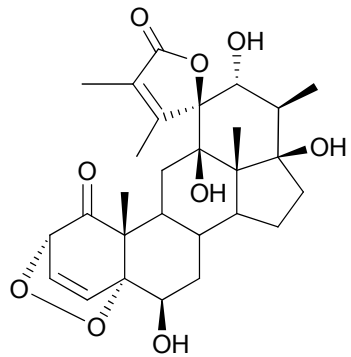<smiles>C=C(C)[C@H](O)Cc1c2c(c(O)c3c(=O)c(-c4ccc(O)cc4)coc13)C=CC(C)(C)O2</smiles>

561<smiles>COc1cc(/C=C\C=O)cc(O)c1-c1c(O)cc([C@@H]2OO[C@H]2CO)cc1O</smiles>

564<smiles>CC(=O)c1c(O)c(CC=C(C)C)c(O)c2c1O[C@](C)(CCC=C(C)C)[C@H](O)C2</smiles>

567<smiles>C=C(C)[C@H](O)Cc1c2c(c(O)c3c(=O)c4cc(O)ccc4oc13)C=CC(C)(C)O2</smiles>

562<smiles>CC(=O)C1=C(O)C(CC=C(C)C)(CC=C(C)C)C(=O)[C@]2(C[C@H](O)[C@H]3CC[C@](C)(O)[C@@H]3C2)C1=O</smiles>

565<smiles>COc1cc2c(c(OC)c1OC)-c1c(cc3c(c1OC)OCO3)C(=O)[C@H](O)[C@H](C)C2</smiles><smiles>CC(=O)C1=C(O)C(CC=C(C)C)(CC=C(C)C)C(=O)[C@]2(C[C@H](O)[C@H]3CC[C@](C)(O)[C@@H]3C2)C1=O</smiles>

566<smiles>C[C@H]1OC(=O)/C(=C/CCCCCCCCC[C@H]2C=CCOO2)[C@@H]1O</smiles><smiles>C[C@@H]1OC(=O)/C(=C\CCCCCCCCC[C@@H]2C=CCOO2)[C@H]1O</smiles>

569

the marine sponge Spirastrella abata showed cytotoxicity against several human solid tumor cell lines, ${ }^{359}$ and also against human gastric tumor cell line (SNU-1), human hepatoma cell line (SNU-354), human colorectal tumor cell line (SNU-C4), and murine sarcoma-180 were 18.7, 158.2, 84.6 and $74.1 \mu \mathrm{M}\left(\mathrm{IC}_{50}\right)$, respectively. ${ }^{360}$ Ergosterol peroxide from two species of the Pleurotus genus, $P$. eryngii and $P$. ostreatus, exhibited osteoclastogenesis inhibitory and trypanocidal activity, respectively. ${ }^{361,362}$ Ergosterol peroxide was obtained for the first time from Oryza sativa in 2006. This is the first report of potential allelopathic activity of steroids on weeds based on their phytotoxicity on barnyardgrass (Echinochloa crus-galli) as target species. ${ }^{363}$ Ergosterol peroxide was found to be a DNA topoisomerase I inhibitor, ${ }^{364}$ and exhibit potent of rat lens aldose reductase inhibition. ${ }^{365}$ Among the lipophilic extracts of seven traditional edible mushrooms, the acetone extract of Sarcodon aspratus markedly inhibited the growth of HL60 human leukemia cells and induced apoptosis after $24 \mathrm{~h}$ incubation. The major active component was identified as ergosterol peroxide. It is completely inhibited growth and induced apoptosis of HL60 cells at a concentration of $25 \mu \mathrm{M}^{366}$ Anti-inflammatory activity has been found for ergosterol peroxide isolated from several species. ${ }^{367-369}$ Ergosterol peroxide also displayed strong anticomplement activity on the classical pathway with $\mathrm{IC}_{50}$ values of $126.8 \mu \mathrm{M} .{ }^{370}$ In addition, the antimicrobial, ${ }^{371,372}$ antituberculosis, ${ }^{373}$ and melanogenesis inhibitory effects ${ }^{374}$ of ergosterol peroxide have also been reported.

In addition to ergosterol peroxide, a number of other steroidal endoperoxides have been reported, which are most commonly $5 \alpha, 8 \alpha$-epidioxysterols with variations in the side chains. A $5 \alpha, 8 \alpha$-epidioxysterol sulfate $\mathbf{5 9 2}$ was isolated from the cultured diatom Odontella aurita. $^{375}$ Four steroidal saponins, pariposides A-D 593-596, were isolated from the roots of Paris polyphyllava. These compounds are the first spirostanol saponins with a peroxy group located between C-5 and $\mathrm{C}-8$ of the aglycon. ${ }^{376}$ Bioassay-guided fractionation of an 


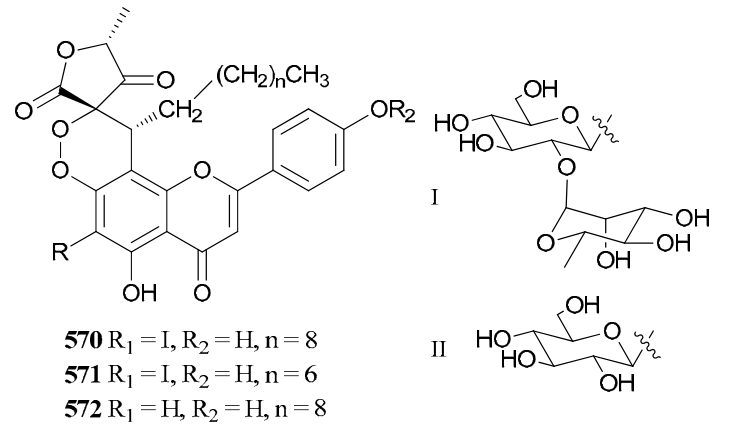

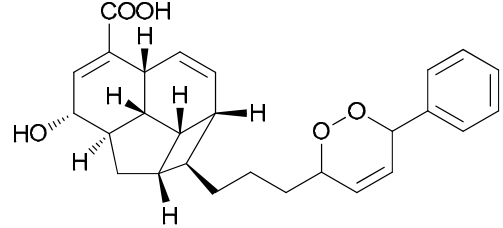

573

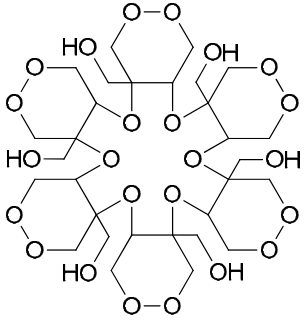

574<smiles>COc1c2ccoc2c(OC/C=C(\C)C/C=C/C(C)(C)O)c2oc(=O)ccc12</smiles><smiles>C=C(C)C(O)CC/C(C)=C/COc1c2occc2c(OC)c2ccc(=O)oc12</smiles><smiles>CC(C)=CCC/C(C)=C/CC/C(C)=C/CC/C(C)=C/CCC1(C)CCc2cc(OOc3cc(C)c4c(c3)OC(C)(CC/C=C(\C)CCC=C(C)C)CC4)cc(C)c2O1</smiles>

579

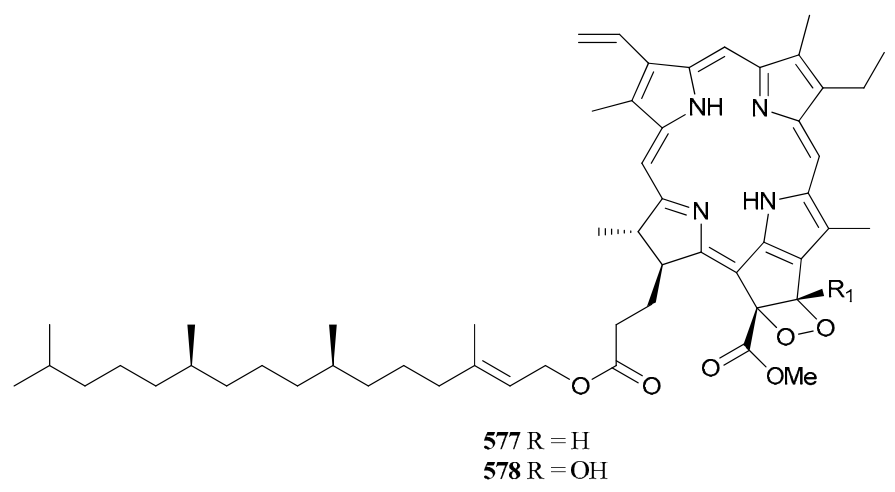<smiles>[R2]c1cc2c(c(C)c1C(=O)O)C(=O)c1c(ccc(C)c1O)[C@@]2(C)OO[C@@]1(C)c2cc(O)c(C(=O)O)c(C)c2C(=O)c2c1ccc(C)c2O</smiles>

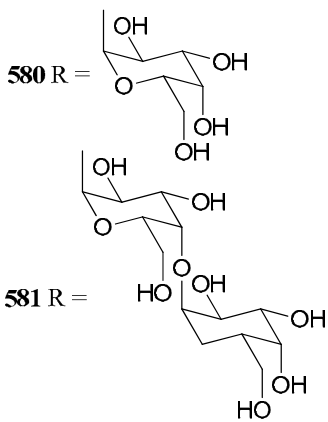<smiles>OCCc1ccc(OOc2ccc(CCO)cc2)cc1</smiles>

582

extract of a marine sponge, Lendenfeldia chondrodes, has led to the isolation and identification of new epidioxy sterols $\mathbf{5 9 7}$ and $\mathbf{5 9 8}$ as an inseparable mixture, which might be formed in the sponge during sample storage and extraction. ${ }^{377}$ A cytotoxic $5 \alpha, 8 \alpha$-epidioxysterol $\mathbf{5 9 9}$ was isolated from a soft coral Sinularia sp. $^{378}$ Sinularia flexibilis (Hainan Is., China) afforded two new members of the $5 \alpha, 8 \alpha$-epidioxygorgostane family of metabolites $\mathbf{6 0 0}$ and $\mathbf{6 0 1}$, as well as the $22 \alpha, 28$ epidioxycholestane C-22 epimers 602 and $\mathbf{6 0 3} .{ }^{379}$ A group of $5 \alpha, 8 \alpha$-epidioxysterols, topsentisterols A1-A3 604-606, were isolated from a marine sponge Topsentia sp. ${ }^{380}$ The marine sponge Luffariella cf. variabilis was the source for a series of $5 \alpha, 8 \alpha$-epidioxy sterols $\mathbf{6 0 7 - 6 0 9} .^{381}$ Eunicella cavolini (Lichadonissia Is., Greece) provided another group of $5 \alpha, 8 \alpha-$ epidioxysterols 610-612. ${ }^{382}$ Three epoxysteroids 613, 614 ${ }^{383}$ and $\mathbf{6 1 5}^{384}$ were obtained from Helianthus tuberosus and Lentinus edodes, respectively. An undescribed endophytic Phomopsis species from Maytenus hookeri provided a new sterol 616. ${ }^{385}$ A peroxy steroid, 9(11)-dehydroxyaxinysterol 617, from an Okinawan species of the genus Axinyssa, was found to inhibit the growth of several human cancer cell lines. ${ }^{386}$ Fermentation of a Rhizopus sp. from the bryozoan Bugula sp. (Jiaozhou Bay, China) yielded a cytotoxic ergosterol $618 .^{387}$

In addition, several rare $5 \alpha, 9 \alpha$-epidioxy steroids have also been characterized. The mushroom Pleurotus eryngii afforded the first example of a naturally occurring $5 \alpha, 9 \alpha$-epidioxy$8 \alpha, 14 \alpha$-epoxy-6-ene sterol $\mathbf{6 1 9} .^{388}$ One osteoclast-forming suppressing sterol, gargalol B 620, was obtained from the mushroom Grifola gargal. ${ }^{389}$ The mushroom Lepista nuda was the source for two new sterols, 621 and its C-6 epimer $\mathbf{6 2 2}$. $^{390}$ Another two compounds of this class, 623 and $\mathbf{6 2 4}$, were isolated from the mushroom Hypsizigus marmoreus. ${ }^{384}$

Besides endoperoxides, steroids containing hydroperoxy groups have also been identified. Two isomeric hydroperoxides, 625 and $\mathbf{6 2 6}$, previously reported as synthetic products, were isolated as mildly cytotoxic metabolites of a Taiwanese collection of Eudistoma sp. ${ }^{391}$ Three cytotoxic oxygenated fucosterols 627-629 were obtained from the marine brown alga Turbinaria conoides. ${ }^{392}$ A Formosan soft coral sinularia sp. was the source for $7 \beta$-hydroperoxy-24-methylenecholesterol 630, which exhibited significant cytotoxicity against P-388 tumor cell with a $\mathrm{ED}_{50}$ of $2.6 \mu \mathrm{g} / \mathrm{mL}{ }^{393}$ A pair of allylic regioisomers, $\mathbf{6 3 1}$ and 632, were found from the bark of Melia azedarach, which showed significant cytotoxic effects against several human cancer cell lines. ${ }^{394}$ A pregnane- 
<smiles>COC(=O)c1cc(OC)c2[nH]c3ccccc3c2c1/C=C/C(C)(C)O</smiles>

583<smiles>C=C(C)C(Cc1cc(C(=O)OC)ccc1O)OO</smiles>

584<smiles>C=C(C)[C@H](O)Cc1cc(C(C)=O)ccc1O</smiles>

585<smiles>C=C(CC(=O)c1cc(O)ccc1O)C1CCC(C)(C)OO1</smiles>

586<smiles>[R]OC1OOC([R20])C(C=C)=C1C=C</smiles>

587<smiles>OC1COOOC1C1OCCO1</smiles>

588
$\overbrace{\mathrm{N}}^{\mathrm{N}} \mathrm{OOC}\left(\mathrm{CH}_{3}\right)_{2} \mathrm{C}\left(\mathrm{CH}_{3}\right)=\mathrm{CH}_{2}$

589

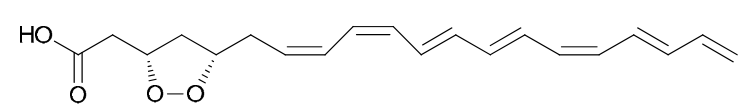

590

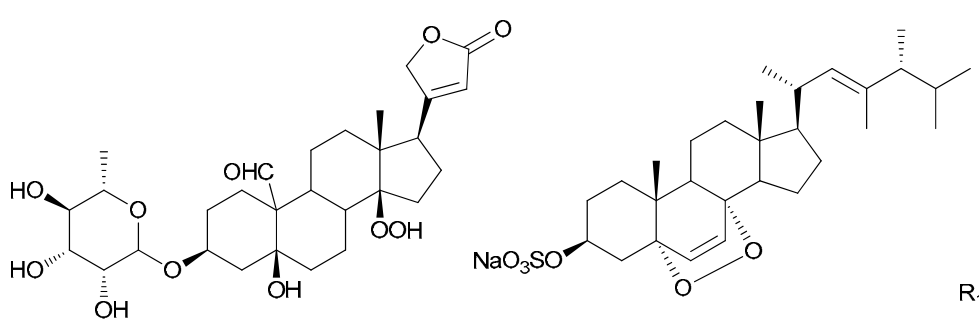

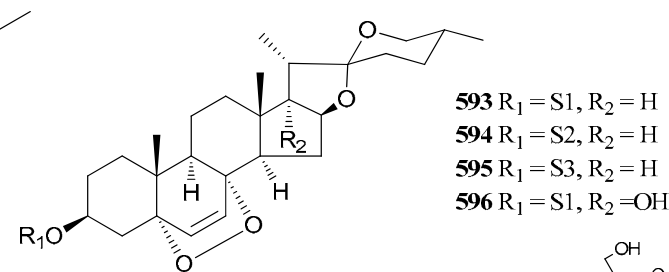

591

592

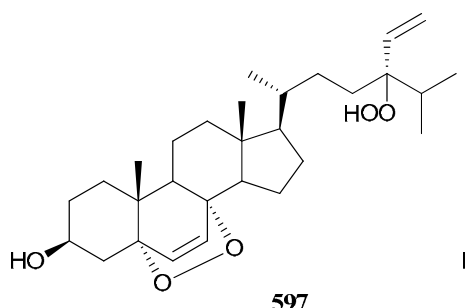<smiles>C=CC(O)(CC[C@@H](C)C1CCC2C3C=CC4(C)CC(O)CCC4(C)C3CC[C@]21C)C(C)C</smiles>

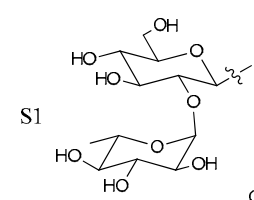

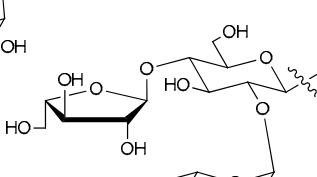

S3<smiles>OC1COC2CC1C(O)C1OC21</smiles>

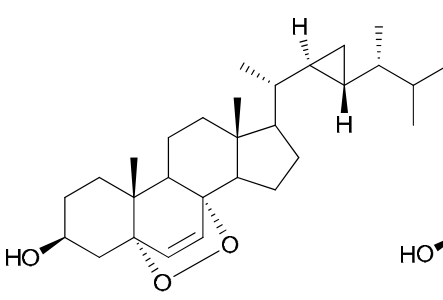

599

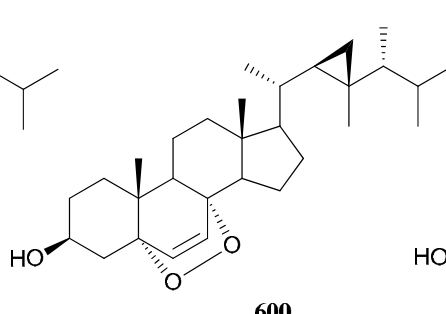

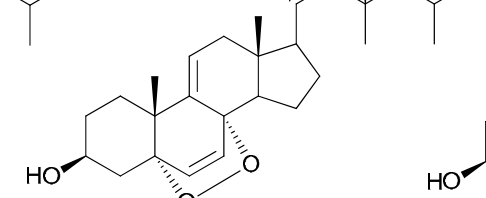<smiles>CC1CCCC2C1CCC1(C)CCCC21C</smiles>

601

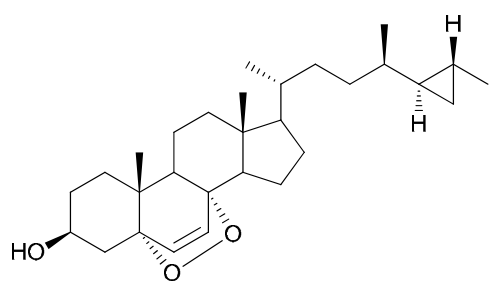

604

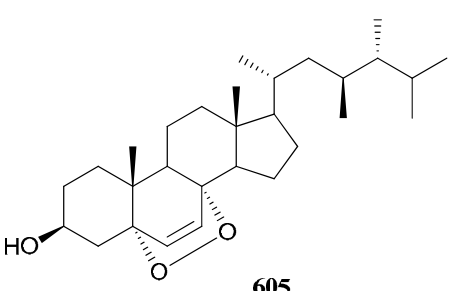

$60322 R$

605

type steroid sclerosteroid E $\mathbf{6 3 3}$ was a constituent of the soft coral Scleronephthya gracillimum. ${ }^{395}$ A chemical investigation of the roots of Cynanchum stauntonii has resulted in the characterization of a new hydroperoxide with a 13,14:14,15disecopregnane-type skeleton, named stauntonine 634, whose relative stereochemistry was determined by X-ray crystallographic diffraction analysis. The compound showed dosedependent relaxation on aortic rings with endothelium contracted by phenylepherine or KCI. ${ }^{396}$
The structures of a series of peroxy function containing pregnane glycosides including periperoxides A-E 635-639 ${ }^{397}$ and previously reported periplocosides $A-K^{398,399}$ have been revised to be orthoester group bearing ones using 2D NMR techniques as well as chemical transformations and X-ray crystallographic diffraction analysis. ${ }^{400}$

\section{Fatty Acid Metabolites}

Lipoxygenase (LOX) pathways are involved in the 


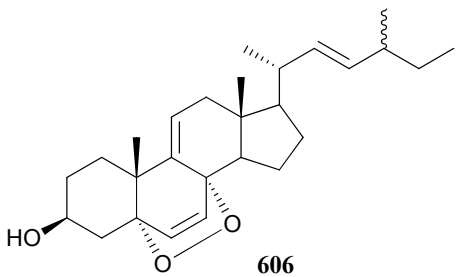

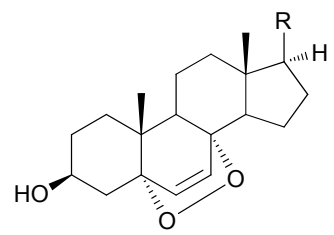<smiles>[R][CH]C(C)/C=C\[C@@H](C)C(C)C</smiles>
$608 \mathrm{R}=$<smiles>CCC(CCC(C)C)C(C)C</smiles>

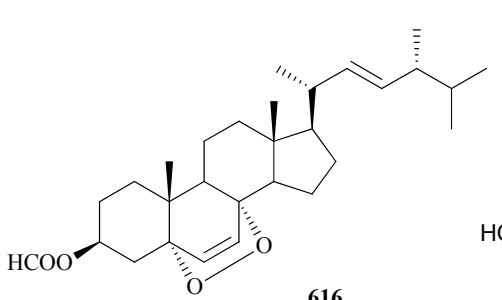

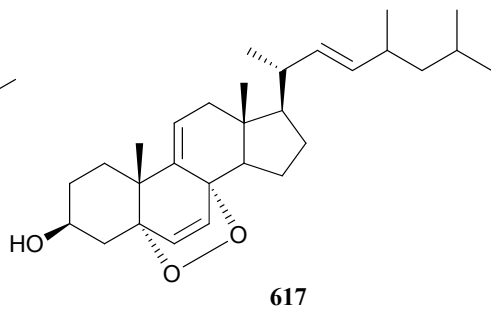

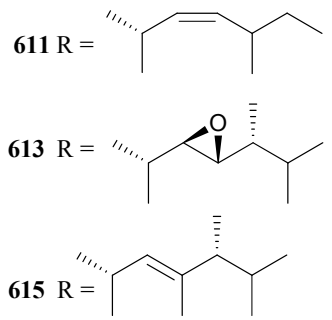

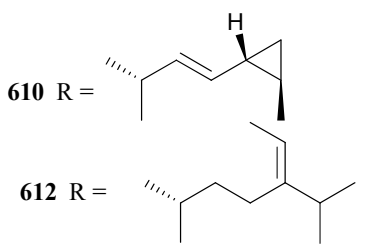<smiles>CC(C)C(C)C1OC1C(C)C=[W]</smiles>

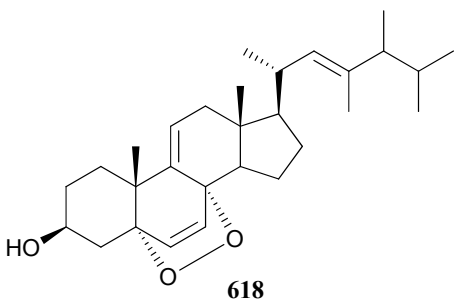

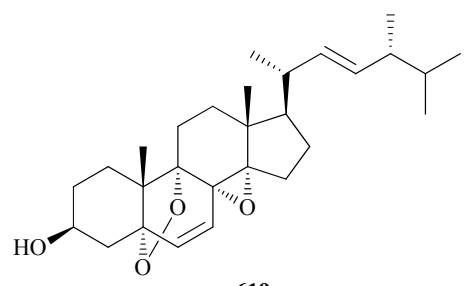<smiles></smiles>

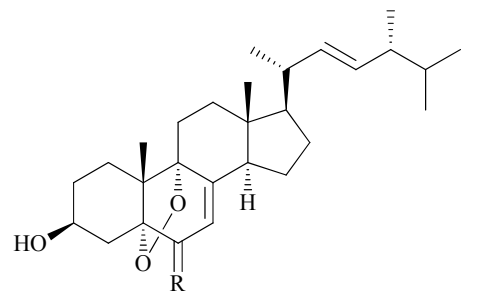

$621 \mathrm{R}=\alpha-\mathrm{OH}, \beta-\mathrm{H}$ $622 \mathrm{R}=\beta-\mathrm{OH}, \alpha-\mathrm{H}$

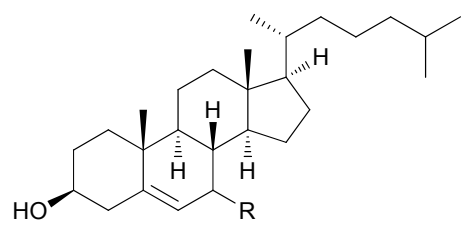

$625 \mathrm{R}=\beta-\mathrm{OOH}$ $626 \mathrm{R}=\alpha-\mathrm{OOH}$<smiles></smiles>

623<smiles>C=C[C@](O)(CC[C@H](C)C1CCC2C3CCC4=CC(=O)CC[C@]4(C)C3CC[C@@]21C)C(C)C</smiles>

627

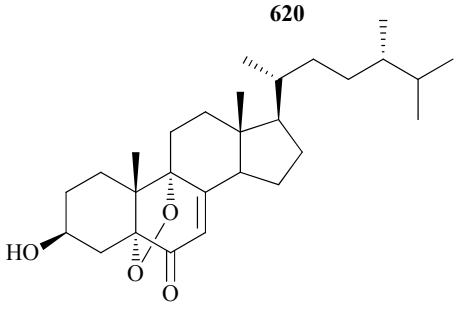

624<smiles>C=CC(O)(CC[C@H](C)C1CCC2C3CC(=O)C4=CC(=O)CC[C@]4(C)C3CC[C@@]21C)C(C)C</smiles>

production of important signal and defensive metabolites in mammals, higher plants, and algae. ${ }^{401-404}$ In these pathways molecular oxygen is introduced into a polyunsaturated fatty acid to form an intermediate hydroperoxide, which may then be cleaved to give shorter chain-length oxygenated products, collectively known as oxylipins. Interestingly, different principles of transformations have been identified. While plants use almost exclusively $\mathrm{C} 18$ fatty acids for the production of oxylipins, ${ }^{401}$ algae and animals rely predominantly on the transformation of $\mathrm{C} 20$ fatty acids. ${ }^{403}$ In animals cleavage of the intermediate hydroperoxy fatty acids is achieved by a dual

\section{望 Springer}

function of LOXes, while plants and algae rely often on hydroperoxide lyases (HPLs) to produce shorter chain oxylipins. ${ }^{401-403}$

The mechanism of fatty acid transformation in the Diatom Thalassiosira rotula does not, however, follow established lipoxygenase/hydroperoxide lyase pathways known from higher plants or mammals but rather relies on a unique transformation of polyunsaturated hydroperoxy fatty acids. These intermediates are then transformed to polyunsaturated short chain aldehydes and short chain hydroxylated fatty acids, which are novel oxylipins. ${ }^{404}$ The similar transformation mechanism of fatty acid hydroperoxides has also been reported 
<smiles>C=CC(O)(CC[C@H](C)C1CCC2C3C[C@H](O)C4=CC(=O)CC[C@]4(C)C3CC[C@]21C)C(C)C</smiles>

629<smiles>C/C=C/[C@](O)(CC[C@H](C)[C@H]1CC[C@H]2C3=CCC4C[C@@H](O)CC[C@]4(C)[C@H]3CC[C@]21C)C(C)C</smiles>

632

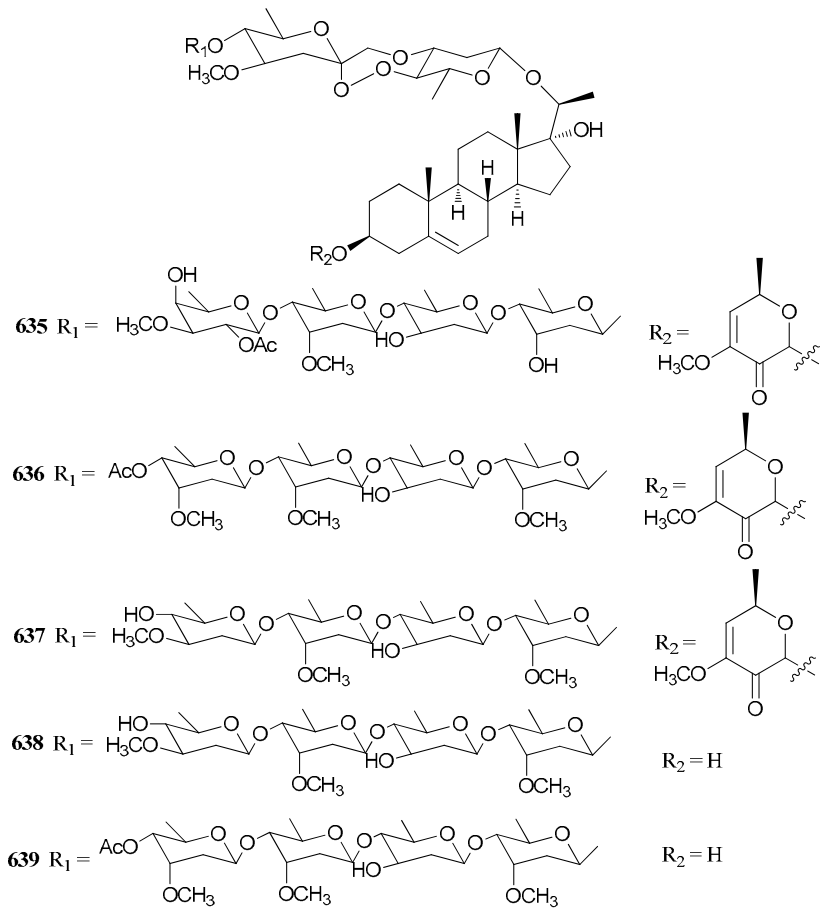

from the moss Physcomitrella patens. The moss produces metabolites typical for animals, plants, algae, and mushrooms by new transformations of arachidonic acid, combining in a unique way metabolic themes from all these organisms. ${ }^{405}$ Recent genome sequences leading to an increasing number of enzyme-mechanistic and structural analysis of LOXs and new members of the oxylipin pathway, as well as oxylipin profiling shed new light on the biosynthesis and occurrence of oxylipins in non-mammalian organisms. A review of these new aspects has been published. ${ }^{406}$<smiles>CC(C)/C(=C/CO)CC[C@H](C)[C@H]1CC[C@H]2C3=CCC4C[C@@H](O)CC[C@]4(C)[C@H]3CC[C@]21C</smiles>

631<smiles>C[C@]12CC[C@@H](O)CC1=CC[C@H]1C(=O)O[C@H]3CO[C@]4(C)O[C@H](O)/C(=C/C[C@@H]12)[C@H]34</smiles>

634

\section{Conclusions}

This article reviewed several hundreds of new peroxy natural products produced by terrestrial fungi, higher plants, and marine organisms not only their structures and chemistry, but also their diverse biological activities. However, only a limited number of them have been further evaluated since a limited supply of the active ingredients from the natural sources. It needs more research attention on total synthesis of important compounds and further biological evaluation. Further studies on their previously untapped resources with further unprecedented bioactive metabolites needs to be conducted. This review also emphasizes the role of peroxides from terrestrial fungi, higher plants, and marine organisms as an important source of leads for drug discovery.

\section{Acknowledgements}

This study was supported by the National Natural Science Foundation of China (NSFC 31100012, U1132607) and the National Basic Research Program of China (973 Program, 2009CB522300).

Open Access This article is distributed under the terms of the Creative Commons Attribution License which permits any use, distribution, and reproduction in any medium, provided the original author(s) and source are credited.

\section{References}

[1] Casteel, D. A. Nat. Prod. Rep. 1992, 9, 289.

[2] Casteel, D. A. Nat. Prod. Rep. 1999, 16, 55.

[3] Dembitsky, V. M.; Gloriozova, T. A.; Poroikov, V. V. Mini. Rev. Med. Chem. 2007, 7, 571.

[4] Dembitsky, V. M. Eur. J. Med. Chem. 2008, 43, 223.

[5] Jung, M.; Kim, H.; Lee, K.; Park, M. Mini. Rev. Med. Chem. 2003, 3, 159.

[6] Varoglu, M.; Peters, B. M.; Crews, P. J. Nat. Prod. 1995, 58, 27. 
[7] Yong, K. W. L.; De Voss, J. J.; Hooper, J. N. A.; Garson, M. J. J. Nat. Prod. 2011, 74, 194.

[8] Barnych, B.; Vatele, J. M. Org. Lett. 2012, 14, 564.

[9] Yong, K. W. L.; Lambert, L. K.; Hayes, P. Y.; De Voss, J. J.; Garson, M. J. J. Nat. Prod. 2012, 75, 351 .

[10] Perry, T. L.; Dickerson, A.; Khan, A. A.; Kondru, R. K.; Beratan, D. N.; Wipf, P.; Kelly, M.; Hamann, M. T. Tetrahedron 2001, $57,1483$.

[11] Chen, Y.; Killday, K. B.; McCarthy, P. J.; Schimoler, R.; Chilson, K.; Selitrennikoff, C.; Pomponi, S. A.; Wright, A. E. J. Nat. Prod. 2001, 64, 262.

[12] Rudi, A.; Afanii, R.; Gravalos, L. G.; Aknin, M.; Gaydou, E.; Vacelet, J.; Kashman, Y. J. Nat. Prod. 2003, 66, 682.

[13] Yong, K. W. L.; Barnych, B.; De Voss, J. J.; Vatele, J. M.; Garson, M. J. J. Nat. Prod. 2012, 75, 1792.

[14] Qureshi, A.; Salv á, J.; Harper, M. K.; Faulkner, D. J. J. Nat. Prod. 1998, 61, 1539.

[15] Jung, M.; Ham, J.; Song, J. Org. Lett. 2002, 4, 2763.

[16] Jiménez-Romero, C.; I. Ortiz, J. Vicente, B. Vera, A. D. Rodriguez, S. Nam, and R. Jove, J. Nat. Prod. 2010, 73, 1694.

[17] Barnych, B.; Vatele, J. M. Synlett 2011, 13, 1912.

[18] Barnych, B.; Vatele, J. M. Tetrahedron 2012, 68, 3717.

[19] Fontana, A.; González, M. C.; Gavagnin, M.; Templado, J.; Cimino, G. Tetrahedron Lett. 2000, 41, 429.

[20] Durán, R.; Zubía, E.; Ortega, M. J.; Naranjo, S.; Salvá, J. Tetrahedron 2000, 56, 6031.

[21] Fontana, A.; Cimino, G.; Gavagnin, M.; Gonzalez, M. C.; Estornell, E. J. Med. Chem. 2001, 44, 2362.

[22] Davies-Coleman, M. T.; Cantrell, C. L.; Gustafson, K. R.; Beutler, J. A.; Pannell, L. K.; Boyd, M. R. J. Nat. Prod. 2000, 63, 1411

[23] Reyes, F.; Rodríguez-Acebes, R.; Fernández, R.; Bueno, S.; Francesch, A.; Cuevas, C. J. Nat. Prod. 2010, 73, 83.

[24] Berrué, F.; Thomas, O. P.; Bon, C. F. L.; Reyes, F.; Amade, P. Tetrahedron 2005, 61, 11843.

[25] Campagnuolo, C.; Fattorusso, E.; Romano, A.; TaglialatelaScafati, O.; Basilico, N.; Parapini, S.; Taramelli, D. Eur. J. Org. Chem. 2005, 23, 5077.

[26] Cafieri, F.; Fattorusso, E.; Taglialatela-Scafati, O.; Ianaro, A. Tetrahedron 1999, 55, 7045 .

[27] Fattorusso, E.; Tagliatatela-Scafati, O.; Di Rosa, M.; Ianaro, A. Tetrahedron 2000, 56, 7959.

[28] Gemma, S.; Gabellieri, E.; Coccone, S. S.; Marti, F.; Taglialatela-Scafati, O.; Novellino, E.; Campiani, G.; Butini, S. J. Org. Chem. 2010, 75, 2333.

[29] Taglialatela-Scafati, O.; Fattorusso, E.; Romano, A.; Scala, F.; Barone, V.; Cimino, P.; Stendardo, E.; Catalanotti, B.; Persico, M.; Fattorusso, C. Org. Biomol. Chem. 2010, 8, 846.

[30] Feng, Y.; Davis, R. A.; Sykes, M.; Avery, V. M.; Camp, D.; Quinn, R. J. J. Nat. Prod. 2010, 73, 716.

[31] Fontana, A.; Ishibashi, M.; Kobayashi, J. Tetrahedron 1998, 54, 2041.

[32] Fontana, A.; Ishibashi, M.; Shigemori, H.; Kobayashi, J. J. Nat. Prod. 1998, 61, 1427.

[33] Compagnone, R. S.; Piña, I. C.; Rangel, H. R.; Dagger, F.; Suárez, A. I.; Reddy, M. V. R.; Faulkner, D. J. Tetrahedron 1998, 54, 3057.

[34] Braekman, J. C.; Daloze, D.; De Groote, S.; Fernandes, J. B.; Van Soest, R. W. M. J. Nat. Prod. 1998, 61, 1038.

[35] Gunasekera, S. P.; Gunasekera, M.; Gunawardana, G. P.; McCarthy, P.; Burres, N. J. Nat. Prod. 1990, 53, 669.

[36] Yao, G.; Steliou, K. Org. Lett. 2002, 4, 485.

[37] Lim, C. W.; Cha, Y. J.; Kim, J. S. J. Fisheries Sci. Technol. 2005 $8,6$.

[38] Hu, J. F.; Gao, H. F.; Kelly, M.; Hamann, M. T. Tetrahedron 2001, 57, 9379 .

[39] Jiménez, M. del-S.; Garzón, S. P.; Rodríguez, A. D. J. Nat. Prod. 2003, 66, 655 .
[40] Yanai, M.; Ohta, S.; Ohta, E.; Hirata, T.; Ikegami, S. Bioorg. Med. Chem. 2003, 11, 1715.

[41] Kossuga, M. H.; Nascimento, A. M.; Reimão, J. Q.; Tempone, A. G.; Taniwaki, N. N.; Veloso, K.; Ferreira, A. G.; Cavalcanti, B. C.; Pessoa, C.; Moraes, M. O.; Mayer, A. M. S.; Hajdu, E.; Berlinck, R. G. S. J. Nat. Prod. 2008, 71, 334

[42] Holzwarth, M.; Trendel, J. M.; Albrecht, P.; Maier, A.; Michaelis, W. J. Nat. Prod. 2005, 68, 759 .

[43] Pettit, G. R.; Nogawa, T.; Knight, J. C.; Doubek, D. L.; Hooper, J. N. A. J. Nat. Prod. 2004, 67, 1611 .

[44] Harrison, B.; Crews, P. J. Nat. Prod. 1998, 61, 1033.

[45] Takada, N.; Watanabe, M.; Yamada, A.; Suenaga, K.; Yamada, K.; Ueda, K.; Uemura, D. J. Nat. Prod. 2001, 64, 356.

[46] Patil, A. D.; Freyer, A. J.; Carte, B.; Johnson, R. K.; Lahouratate, P. J. Nat. Prod. 1996, 59, 219.

[47] Xu, T.; Feng, Q.; Jacob, M. R.; Avula, B.; Mask, M. M.; Baer son, S. R.; Tr ip at hi, S . K.; Moh am med, R.; Hamann, M. T.; Khan, I. A.; Walker, L. A.; Clark, A. M.; Agarwal, A. K. Antimicrob. Agents Chemother. 2011, 55, 1611.

[48] Chen, Y.; McCarthy, P. J.; Harmody, D. K.; SchimolerO'Rourke, R.; Chilson, K.; Selitrennikoff, C.; Pomponi, S. A.; Wright, A. E. J. Nat. Prod. 2002, 65, 1509.

[49] Dalisay, D. S.; Quach, T.; Molinski, T. F. Org. Lett. 2010, 12 , 1524.

[50] Faulkner, D. J.; Armstrong, R. W.; Djura, P.; Higgs, M. D.; Ravi, B. N.; Stierle, D. B.; Wratten, S. J. J. Colloq. Int. C.N.R.S. 1979, 291.

[51] Williams, D. E.; Allen, T. M.; van Soest, R. B.; Behrish, W.; Andersen, R. J. J. Nat. Prod. 2001, 64, 281.

[52] Manzo, E.; Ciavatta, M. L.; Melck, D.; Schupp, P.; de Voogd, N.; Gavagnin, M. J. Nat. Prod. 2009, 72, 1547.

[53] Dalisay, D. S.; Quach, T.; Nicholas, G. N.; Molinski, T. F. Angew. Chem. Int. Ed. 2009, 48, 4367.

[54] Ovenden, S. P. B.; Capon, R. J. J. Nat. Prod. 1999, 62, 214.

[55] El Sayed, K. A.; Hamann, M. T.; Hashish, N. E.; Shier, W. T.; Kelly, M.; Khan, A. A. J. Nat. Prod. 2001, 64, 522.

[56] Youssef, D. T. A.; Yoshida, W. Y.; Kelly, M.; Scheuer, P. J. J. Nat. Prod. 2001, 64, 1332.

[57] Youssef, D. T. A. J. Nat. Prod. 2004, 67, 112.

[58] Dai, J.; Liu, Y.; Zhou, Y. D.; Nagle, D. G. J. Nat. Prod. 2007, 70, 130.

[59] Ibrahim, S. R. M.; Ebel, R.; Wray, V.; Müller, W. E. G.; EdradaEbel, R.; Proksch, P. J. Nat. Prod. 2008, 71, 1358

[60] Ibrahim, S. R. M. Nat. Prod. Commun. 2012, 7, 9.

[61] Rubio, B. K.; Tenney, K.; Ang, K. H.; Abdulla, M.; Arkin, M. McKerrow, J. H.; Crews, P. J. Nat. Prod. 2009, 72, 218.

[62] Sperry, S.; Valeriote, F. A.; Corbett, T. H.; Crews, P. J. Nat. Prod. 1998, 61, 241

[63] Cheenpracha, S.; Park, E. J.; Rostama, B.; Pezzuto, J. M.; ; Chang, L. C. Mar. Drugs 2010, 8, 429.

[64] Park, E. J.; Cheenpracha, S.; Chang, L. C.; ; Pezzuto, J. M. Phytochem. Lett. 2011, 4, 426.

[65] Park, E. J.; Cheenpracha, S.; Chang, L. C.; Kondratyuk, T. P.; Pezzuto, J. M. Pharm. Biol. 2012, 50, 54

[66] Ambrosio, M. D.; Guerriero, A.; Deharo, E.; Debitus, C.; Munoz, V.; Pietra, F. Helv. Chim. Acta. 1998, 81, 1285.

[67] Chao, C. H.; Chou, K. J.; Wang, G. H.; Wu, Y. C.; Wang, L. H.; Chen, J. P.; Sheu, J. H.; Sung, P. J. J. Nat. Prod. 2010, 73, 1538.

[68] Ovenden, S. P. B.; Capon, R. J. Aust. J. Chem. 1998, 51, 573.

[69] Capon, R. J.; Rochfort, S. J.; Ovenden, S. P. B.; Metzger, R. P. J. Nat. Prod. 1998, 61, 525.

[70] Phuwapraisirisan, P.; Matsunaga, S.; Fusetani, N.; Chaitanawisuti, N.; Kritsanapuntu, S.; Menasveta, P. J. Nat. Prod. 2003, 66, 289.

[71] Tanaka, J. I.; Higa, T.; Suwanborirux, K.; Kokpol, U.; Bernardinelli, G.; Jefford, C. W. J. Org. Chem. 1993, 58, 2999.

[72] Silva, E. M. P.; Pye, R. J.; Grown, G. D.; Harwood, L. M. Eur. J. Org. Chem. 2012, 1209. 
[73] Silva, E. M. P.; Pye, R. J.; Cardin, C.; Harwood, L. M. Synlett 2010, 509.

[74] Mohammed, R.; Peng, J.; Kelly, M.; Yousaf, M.; Winn, E.; Odde, S.; Bie, Z.; Xie, A.; Doerksen, R. J.; Hamann, M. T. Aust. J. Chem. 2010, 63, 877.

[75] Sandler, J. S.; Colin, P. L.; Hooper, J. N. A.; Faulkner, D. J. J. Nat. Prod. 2002, 65, 1258.

[76] Phillipson, D. W.; Rinehart Jr., K. L. J. Am. Chem. Soc. 1983, 105,7735 .

[77] Dai, P.; Trullinger, T. K.; Liu, X.; Dussault, P. H. J. Org. Chem 2006, 71, 2283.

[78] Patil, A. D.; Freyer, A. J.; Bean, M. F.; Carte, B. K.; Westley, J. W.; Johnson, R. K.; Lahouratate, P. Tetrahedron 1996, 52, 377.

[79] Sun, X. Y.; Tian, X. Y.; Li, Z. W.; Peng, X. S.; Wong, H. N. C. Chem. Eur. J. 2011, 17, 5874.

[80] Fontana, A.; d 'Ippolito, G.; D'Souza, L.; Mollo, E.; Parameswaram, P. S.; Cimino, G. J. Nat. Prod. 2001, 64, 131

[81] Yosief, T.; Rudi, A.; Wolde-ab, Y.; Kashman, Y. J. Nat. Prod. 1998, 61, 491

[82] Xu, C.; Raible, J. M.; Dussault, P. H. Org. Lett. 2005, 7, 2509.

[83] Fattorusso, C.; Persico, M.; Calcinai, B.; Cerrano, C.; Parapini, S.; Taramelli, D.; Novellino, E.; Romano, A.; Scala, F.; Fattorusso, E.; Taglialatela-Scafati, O. J. Nat. Prod. 2010, 73, 1138.

[84] Chianese, G.; Fattorusso, E.; Scala, F.; Teta, R.; Calcinai, B.; Bavestrello, G.; Dien, H. A.; Kaiser, M.; Tasdemir, D.; Taglialatela-Scafati, O. Org. Biomol. Chem. 2012, 10, 7197.

[85] Wells, R. J. Tetrahedron Lett. 1976, 17, 2637.

[86] Sakemi, S.; Higa, T.; Anthoni, U.; Christophersen, C. Tetrahedron 1987, 43, 263.

[87] Murayama, T.; Ohizumi, Y.; Nakamura, H.; Sasaki, T.; Kobayashi, J. Experientia 1989, 45, 898.

[88] Dussault, P. H.; Eary, C. T.; Woller, K. R. J. Org. Chem. 1999, 64, 1789.

[89] Lai, D. W.; Liu, D.; Deng, Z. W.; van Ofwegen, L.; Proksch, P.; Lin, W. H. J. Nat. Prod. 2012, 75, 1595.

[90] Chen, B. W.; Wu, Y. C.; Chiang, M. Y.; Su, J. H.; Wang, W. H.; Fan, T. Y.; Sheu, J. H. Tetrahedron 2009, 65, 7016.

[91] Cai, Y. S.; Yao, L. G.; Di Pascale, A.; Irace, C.; Mollo, E.; Taglialatela-Scafati, O.; Guo, Y. W. Tetrahedron 2013, 69, 2214.

[92] Ospina, C. A.; Rodríguez, A. D.; Ortega-Barria, E.; Capson, T. L. J. Nat. Prod. 2003, 66, 357.

[93] Rodríguez, A. D.; Cóbar, O. M. Tetrahedron 1995, 51, 6869.

[94] Rodríguez, A. D.; Cóbar, O. M.; Martínez, N. J. Nat. Prod. 1994, 57,1638

[95] Ospina, C. A.; Rodríguez, A. D. J. Nat. Prod. 2006, 69, 1721.

[96] Kusumi, T.; Uchida, H.; Ishitsuka, M. O.; Yamamoto, H.; Kakisawa, H. Chem. Lett. 1988, 1077.

[97] Corminboeuf, O.; Overman, L. E.; Pennington, L. D. Org. Lett. 2003, 5, 1543.

[98] Wei, X.; Rodríguez, A. D.; Baran, P.; Raptis, R. G. J. Nat. Prod. 2010, 73, 925

[99] Yamada, Y.; Yakugaku Zasshi 2002, 122, 727

[100] Xiang, W.; Leng, C. C. Planta Med. 2006, 72, 735.

[101] Duh, C. Y.; Chia, M. C.; Wang, S. K.; Chen, H. J.; El-Gamal, A. A. H.; Dai, C. F. J. Nat. Prod. 2001, 64, 1028

[102] Ciavatta, M. L.; Manzo, E.; Mollo, E.; Mattia, C. A.; Tedesco, C.; Irace, C.; Guo, Y. W.; Li, X. B.; Cimino, G.; Gavagnin, M. J. Nat. Prod. 2011, 74, 1902.

[103] Teasdale, M. E.; Shearer, T. L.; Engel, S.; Alexander, T. S.; Fairchild, C. R.; Prudhomme, J.; Torres, M.; Le Roch, K.; Aalbersberg, W.; Hay, M. E.; Kubanek, J. J. Org. Chem. 2012, 77, 8000 .

[104] Chen, S. P.; Chao, C. H.; Huang, H. C.; Wu,Y. C.; Lu, C. K.; Dai, C. F.; Sheu, J. H. Bull. Chem. Soc. Jpn. 2006, 79, 1547.

[105] (a) Chen, S. P.; Ahmed, A. F.; Dai, C. F.; Lu, C. K.; Hu, W. P.; Wang, J. J.; Sheu, J. H. Tetrahedron 2006, 62, 6802 ; (b) Chen, S. P.; Su, J. H. Yeh, H. C.; Ahmed, A. F.; Dai, C. F.; Wu, Y. C.; Sheu, J. H. Chem. Pharm. Bull. 2009, 57, 162.
[106] Duh, C. Y.; El-Gamal, A. A. H.; Chiang, C. Y.; Chu, C. J.; Wang, S. K.; Dai, C. F. J. Nat. Prod. 2002, 65, 1882.

[107] Sabry, O. M. M.; Andrews, S.; McPhail, K. L.; Goeger, D. E.; Yokochi, A.; LePage, K. T.; Murray, T. F.; Gerwick, W. H. J. Nat.Prod. 2005, 68, 1022.

[108] Cafieri, F.; de Napoli, L.; Fattorusso, E.; Santacroce, C. Phytochemistry 1987, 26, 471.

[109] Cafieri, F.; Ciminiello, P.; Fattorusso, E.; Mangoni, A. Gazz. Chim. Ital. 1990, 120, 139.

[110] Smyrniotopoulos, V.; Quesada, A.; Vagias, C.; Moreau, D.; Roussakis, C.; Roussis, V. Tetrahedron 2008, 64, 5184.

[111] Smyrniotopoulos, V.; Vagias, C.; Rahman, M. M.; Gibbons, S.; Roussis, V. J. Nat. Prod. 2008, 71, 1386.

[112] Su, J. H.; Sung, P. J.; Kuo, Y. H.; Hsu, C. H.; Sheu, J. H. Tetrahedron 2007, 63, 8282 .

[113] Sung, P. J.; Lin, M. R.; Chiang, M. Y.; Huang, I. C.; Syu, S. M.; Fang, L. S.; Wang, W. H.; Sheu, J. H. Chem. Lett. 2010, 39, 1030.

[114] Fernández, J. J.; Souto, M. L.; Gil, L. V.; Norte, M. Tetrahedron 2005, 61, 8910.

[115] Yin, S. W.; Shi, Y. P.; Li, X. M.; Wang, B. G. Helv. Chim. Acta 2006, 89,567 .

[116] Chao, C. H.; Wen, Z. H.; Wu, Y. C.; Yeh, H. C.; Sheu, J. H. J. Nat. Prod. 2008, 71, 1819.

[117] Lin, Y. S.; Chen, C. H.; Liaw, C. C.; Chen, Y. C.; Kuo, Y. H. Shen, Y. C. Tetrahedron 2009, 65, 9157.

[118] Lo, K. L.; Khalil, A. T.; Kuo, Y. H.; Shen, Y. C. Chem. Biodiversity 2009, 6,2227

[119] Su, J. H.; Ahmed, A. F.; Sung, P. J.; Chao, C. H.; Kuo, Y. H.; Sheu, J. H. J. Nat. Prod. 2006, 69, 1134.

[120] Rodríguez, A. D.; Piña, I. C.; Soto, J. J.; Rojas, D. R.; Barnes, C. L. Can. J. Chem. 1995, 73, 643.

[121] Rodr íguez, A. D.; Acosta, A. L. J. Nat. Prod. 1998, 61, 40.

[122] Shi, Y. P.; Rodríguez, A. D.; Barnes, C. L.; Sánchez, J. A.; Raptis, R. G.; Baran, P. J. Nat. Prod. 2002, 65, 1232

[123] Xu, X. H.; Kong, C. H.; Lin, C. J.; Wang, X.; Zhu, Y. D.; Yang, H. S. Chin. J. Chem. 2003, 21, 1506.

[124] Lin, W. Y.; Lu, Y.; Su, J. H.; Wen, Z. H.; Dai, C. F.; Kuo, Y. H.; Sheu, J. H. Mar. Drugs 2011, 9, 994.

[125] Hegazy, M. E. F.; Eldeen, A. M. G.; Shahat, A. A.; Abdel-Latif, F. F.; Mohamed, T. A.; Whittlesey, B. R.; Pare, P. W. Mar. Drugs 2012, 10, 209.

[126] Yao, G.; Vidor, N. B.; Foss, A. P.; Chang, L. C. J. Nat. Prod. 2007, 70, 901

[127] Umeyama, A.; Machida, M.; Nozaki, M.; Arihara, S. J. Nat Prod. 1998, 61, 1435.

[128] H. El-Gamal, A. A.; Wang, S. K.; Dai, C. F.; Chen, I. G.; Duh, C. Y. J. Nat. Prod. 2005, 68, 74.

[129] Huang, X. C.; Li, J.; Li, Z. Y.; Shi, L.; Guo, Y. W. J. Nat. Prod. 2008, 71, 1399

[130] Zubía, E.; Ortega, M. J.; Hernández-Guerrero, C. J.; Carballo, J. L. J. Nat. Prod. 2008, 71, 608.

[131] Zubi'a, E.; Ortega, M. J.; Carballo, J. L. J. Nat. Prod. 2008, 71, 2004

[132] Kolesnikova, S. A.; Lyakhova, E. G.; Kalinovsky, A. I.; Dmitrenok, P. S.; Dyshlovoy, S. A.; Stonik, V. A. Aust. J. Chem. 2009, 62, 1185 .

[133] Wang, S. K.; Huang, M. J.; Duh, C. Y. J. Nat. Prod. 2006, 69 , 1411.

[134] Cheng, S. Y.; Dai, C. F.; Duh, C. Y. J. Nat. Prod. 2007, 70, 1449

[135] Cheng, S. Y.; Wang, S. K.; Wen, Z. H.; Dai, C. F.; Duh, C. Y. J. Asian Nat. Prod. Res. 2009, 11, 967.

[136] Chao, C. H.; Hsieh, C. H.; Chen, S. P.; Lu, C. K.; Dai, C. F.; Wu, Y. C.; Sheu, J. H. Tetrahedron Lett. 2006, 47, 2175.

[137] Su, J. H.; Hsieh, C. H.; Lo, C. L.; Huang, C. Y.; Dai, C. F.; Kuo, Y. H.; Sheu, J. H. J. Chin. Chem. Soc. 2008, 55, 1286.

[138] Sawant, S. S.; Youssef, D. T. A.; Sylvester, P. W.; Wali, V.; El 
Sayed, K. A. Nat. Prod Commun 2007, 2, 117.

[139] Flowers, A. E.; Garson, M .J.; Byriel, K. A.; Kennard, C. H. L. Aust. J. Chem. 1998, 51, 195.

[140] Ueda, K.; Kadekaru, T.; Siwu, E. R. O.; Kita, M; Uemura, D. J. Nat. Prod. 2006, 69, 1077.

[141] Mao, S.; Guo, Y. Helv. Chim. Acta. 2005, 88, 1034

[142] Ahmed, A. F.; Kuo, Y. H.; Dai, C. F.; Sheu, J. H. J. Nat. Prod. 2005, 68,1208

[143] Jain, S.; Abraham, I.; Carvalho, P.; Kuang,Y. H.; Shaala, L. A.; Youssef, D. T. A.; Avery, M. A.; Chen, Z. S.; El Sayed, K. A. J. Nat. Prod. 2009, 72, 1291.

[144] Homhual, S.; Bunyapraphatsara, N.; Kondratyuk, T.; Herunsalee, A.; Chaukul, W.; Pezzuto, J. M.; Fong, H. H. S.; Zhang, H. J. J. Nat. Prod. 2006, 69, 421.

[145] Cutignano, A.; Fontana, A.; Renzulli, L.; Cimino, G. J. Nat. Prod. 2003, 66, 1399.

[146] Ji, N. Y.; Li, X. M.; Li, K.; Wang, B. G. J. Nat. Prod. 2007, 70, 1499.

[147] Shen, Y. C.; Prakash, C. V. S.; Guh, J. H. Tetrahedron Lett. 2004, 45, 2463.

[148] Morita, M.; Ohno, O.; Teruya, T.; Yamori, T.; Inuzuka, T.; Suenaga, K. Tetrahedron 2012, 68, 5984

[149] Wang, F.; Fang, Y.; Zhu, T.; Zhang, M.; Lin, A.; Gu, Q.; Zhu, W. Tetrahedron 2008, 64, 7986.

[150] Ueoka, R.; Nakao, Y.; Kawatsu, S.; Yaegashi, J.; Matsumoto, Y.; Matsunaga, S.; Furihata, K.; van Soest, R. W. M.; Fusetani, N. J. Org. Chem. 2009, 74, 4203.

[151] Festa, C.; Lauro, G.; De Marino, S.; D'Auria, M. V.; Monti, M. C.; Casapullo, A.; D’Amore, C.; Renga, B.; Mencarelli, A.; Petek, S.; Bifulco, G.; Fiorucci, S.; Zam-pella, A. J. Med. Chem. 2012, 55, 8303.

[152] Festa, C.; De Marino, S.; D'Auria, M. V.; Deharo, E.; Gonzalez, G.; Deyssard, C.; Petek, S.; Bifulco, G.; Zampella, A. Tetrahedron 2012, 68, 10157.

[153] Fu, X.; Hong, E. P.; Schmitz, F. J. Tetrahedron 2000, 56, 8989.

[154] Sharma, P.; Lygo, B.; Lewis, W.; Moses, J. E. J. Am. Chem. Soc. 2009, 131, 5966

[155] Manzo, E.; Ciavatta, M. L.; Gavagnin, M.; Mollo, E.; Wahidulla, S.; Cimino, G. Tetrahedron Lett. 2005, 46, 465.

[156] Miller, A. K.; Trauner, D. Angew. Chem. Int. Ed. 2005, 44, 4602.

[157] Díaz-Marrero, A. R.; Cueto, M.; D'Croz, L.; Darias, J. Org. Lett. 2008, 10, 3057 .

[158] Cueto, M.; D'Croz, L.; Mate, J. L.; San-Martín, A.; Darias, J. Org. Lett. 2005, 7, 415.

[159] Uchiyama, N.; Matsunaga, K.; Kiuchi, F.; Honda, G.; Tsubouchi, A.; Nakajima-Shimada, J.; Aoki, T. Chem. Pharm. Bull. 2002, 50, 1514.

[160] Kiuchi, F.; Itano, Y.; Uchiyama, N.; Honda, G.; Tsubouchi, A.; Nakajima-Shimada, J.; Aoki, T. J. Nat. Prod. 2002, 65, 509.

[161] Becker, H.; Martini, U. Z. Naturforsch., C: Bio. Sci. 1999, 54, 997.

[162] Jung, C. M.; Kwon, H. C.; Seo, J. J.; Ohizumi, Y.; Matsunaga, K.; Saito, S.; Lee, K. R. Chem. Pharm. Bull. 2001, 49, 912.

[163] Ono, M.; Tsuru, T.; Abe, H.; Eto, M.; Okawa, M.; Abe, F.; Kinjo, J.; Ikeda, T.; Nohara, T. Phytochemistry 1998, 47, 1417.

[164] Fattorusso, E.; Santelia, F. U.; Appendino, G.; Ballero, M.; Taglialatela-Scafati, O. J. Nat. Prod. 2004, 67, 37.

[165] Wang, L.; He, H. P.; Di, Y. T.; Zhang, Y.; Hao, X. J. Tetrahedron Lett. 2012, 53, 1576

[166] Li, H.; Meng, J. C.; Cheng, C. H. K.; Higa, T.; Tanaka, J.; Tan, R. X. J. Nat. Prod. 1999, 62, 1053.

[167] Meng, J. C.; Hu, Y. F.; Chen, J. H.; Tan, R. X. Phytochemistry 2001, 58,1141 .

[168] Todorova, M.; Vogler, B.; Tsankova, E. Z. Naturforsch., Teil C 2000, 55,840

[169] Vajs, V.; Bulatovic, V.; Fodulovic-Savikin, K.; Menkovic, N.; Macura, S.; Juranic, N.; Milosavljevic, S. Phytochemistry 1999,
$50,287$.

170] Wang, X. X.; Lin, C. J.; Jia, Z. J. Planta Med. 2006, 72, 764.

[171] Dong, J. Y.; Ma, X. Y.; Cai, X. Q.; Yan, P. C.; Yue, L.; Lin, C.; Shao, W. W. Phytochemistry 2013, 85, 122.

[172] Zaugg, J.; Eickmeier, E.; Ebrahimi, S. N.; Baburin, I.; Hering S.; Harburger, M. J. Nat. Prod. 2011, 74, 1437.

[173] Takaya, Y.; Kurumada, K. I.; Takeuji, Y.; Kim, H. S.; Shibata, Y.; Ikemoto, N.; Wataya, Y.; Oshima, Y. Tetrahedron Lett. 1998, 39, 1361 .

[174] Takaya, Y.; Takeuji, Y.; Akasaka, M.; Nakagawasai, O. Tadano, T.; Kisara, K.; Kim, H. S.; Wataya, Y.; Niwa, M.; Oshima, Y. Tetrahedron 2000, 56, 7673.

[175] Kiuchi, F.; Matsuo, K.; Ito, M.; Qui, T. Q.; Honda, G. Chem. Pharm. Bull. 2004, 52, 1495.

[176] Aguilar-Guadarrama, A. B.; Rios, M. Y. J. Nat. Prod. 2004, 67, 914.

[177] Müller, S.; Murillo, R.; Castro, V.; Brecht, V.; Merfort, I. J. Nat. Prod. 2004, 67, 622.

[178] Zhang, Q. F.; Luo, S. D.; Wang, H. Y. Chin. Chem. Lett. 1998, 9, 1097.

[179] Lee, S. O.; Choi, S. Z.; Choi, S. U.; Kim, G. H.; Kim,Y. C.; Lee, K. R. Arch. Pharm. Res. 2006, 29, 845.

[180] Choi, S. Z.; Lee, S. O.; Choiand, S. U.; Lee, K. R. Arch. Pharm. Res. 2003, 26, 521

[181] Ma, W. H.; Tan, C. M.; He, J. C.; Duan, P. S.; Qin, L. P. Chem. Nat. Compd. 2011, 47, 713.

[182] Shimizu, Y.; Imayoshi, Y.; Kato, M.; Maeda, K.; Iwabuchi, H.; Shimomura, K. Flavour Fragrance J. 2011, 26, 55.

[183] Moreira, I. C.; Roque, N. F.; Contini, K.; Lago, J. H. G. Rev Bras.Farm. 2007, 17, 55

[184] Zhu, X. D.; Zhang, Q. H.; Kong, L. B.; Wang, F.; Luo, S. D. Fitoterapia 2010, 81, 906.

[185] Ding, L.; Maier, A.; Fiebig, H. H.; Lin, W. H.; Peschel, G.; Hertweck, C. J. Nat. Prod. 2012, 75, 2223.

[186] Gong, H. Q.; Wu, Q. X.; Liu, L. L.; Yang, J. L.; Wang, R.; Shi, Y. P. Helv. Chim. Acta. 2011, 94, 1269.

[187] Ma, B.; Lu, Z. Q.; Guo, H. F.; Lou, H. X. Helv. Chim. Acta 2007, 90, 52.

[188] Xu, J.; Zhao, X. J.; Guo, Y. Q.; Zhang, S. Z. Pharmazie 2009, 64,623 .

[189] Todorova, M. N.; Tsankova, E. T. Phytochemistry 1999, 52, 1515.

[190] Brown, G. D.; Liang, G. Y.; Sy, L. K. Phytochemistry 2003, 64 303

[191] Ono, M.; Tsuro, T.; Abe, H.; Eto, M.; Okawa, M.; Abe, F.; Kinjo, J.; Ikeda, T.; Nohara, T. J. Nat. Prod. 2006, 69, 1417.

[192] Mikhova, M.; Duddeck, H.; Taskova, R.; Mitova, M.; Alipieva, K. Z. Naturforsch., C: Bio. Sci. 2004, 59, 244

[193] Taglialatela-Scafati, O.; Pollastro, F.; Cicione, L.; Chianese, G.; Bellido, M. L.; Munoz, E.; Ozen, H. C.; Toker, Z.; Appendino, G. J. Nat. Prod. 2012, 75, 453.

[194] Trifunovic, S.; Vajs, V.; Juranic, Z.; Zizak, Z.; Tesevic, V.; Macura, S.; Milosavljevic, S. Phytochemistry 2006, 67, 887.

[195] Appendino, G.; Aviello, G.; Ballero, M.; Barreli, F.; Fattorusso, E.; Petrucci, F.; Santelia, F. U.; Taglialatela-Scafati, O. J. Nat. Prod. 2005, 68, 853.

[196] J. J. Qin, H. Z. Jin, J. X. Zhu, J. J. Fu, X. J. Hu, X. H. Liu, Y. Zhu, S. K. Yan, and W. D. Zhang, Planta Med., 2010, 76, 278.

[197] Zhu, J. X.; Qin, J. J.; Jin, H. Z.; Zhang, W. D. Fitoterapia 2013 84,30

[198] Kamperdick, C.; Phuong, N. M.; Sung, T. V.; Adam, G. Phytochemistry 2001, 56, 335.

[199] Kamperdick, C.; Phuong, N. M.; Adam, G.; Sung, T. V. Phytochemistry 2003, 64, 811 .

[200] Kim, S. Y.; Kashiwada, Y.; Kawazoe, K.; Murakami, K.; Sun, H. D.; Li, S. L. Takaishi, Y. Tetrahedron Lett. 2009, 50, 6032.

[201] Fang, P. L.; Cao, Y. L.; Yan, H.; Pan, L. L.; Liu, S. C.; Gong, N. B.; LÜ, Y.; Chen, C. X.; Zhong, H. M.; Guo, Y.; Liu, H. Y. J. Nat. Prod. 2011, 74, 1408. 
[202] Li, Y.; Niu, S. B.; Sun, B. D.; Liu, S. C.; Liu, X. Z.; Che, Y. S. Org. Lett. 2010, 12, 3144 .

[203] Spence, J. T. J.; George, J. H. Org. Lett. 2011, 13, 5318.

[204] Liu, D. Z.; Wang, F.; Liu, J. K. Tetrahedron Lett. 2010, 51, 3152.

[205] Liu, D. Z.; Luo, M. H. Fitoterapia 2010, 81, 1205.

[206] Chokpaiboon, S.; Sommit, D.; Teerawatananond, T.; Muangsin, N.; Bunyapaiboonsri, T.; Pudhom, K. J. Nat. Prod. 2010, 73, 1005.

[207] Chokpaiboon, S.; Sommit, D.; Bunyapaiboonsri, T.; Matsubara, K.; Pudhom, K. J. Nat. Prod. 2011, 74, 2290.

[208] Li, H.; Huang, H.; Shao, C.; Huang, H.; Jiang, J.; Zhu, X.; Liu, Y.; Lu, Y.; Li, M.; Lin, Y.; She, Z. J. Nat. Prod. 2011, 74, 1230.

[20] Nagashima, F.; Suzuki, M.; Takaoka, S.; Asakawa, Y. Chem. Pharm. Bull. 1998, 46, 1184.

[210] Nagashima, F.; Suzuki, M.; Takaoka, S.; Asakawa, Y. Tetrahedron 1999, 55, 9117.

[211] Monde, K.; Taniguchi, T.; Miura, N.; Vairappan, C. S.; Suzuki, M. Chirality 2006, 18,335 .

[212] Monde, K.; Taniguchi, T.; Miura, N.; Vairappan, C. S.; Suzuki, M. Tetrahedron Lett. 2006, 47, 4389.

[213] Ngo, K. S.; Wong, W. T.; Brown, G. D. J. Nat. Prod. 1999, 62, 549 .

[214] Nagashima, F.; Asakawa, Y. Phytochemistry 2001, 56, 347.

[215] Adio, A. M.; König, W. A. Phytochemistry 2005, 66, 599.

[216] Nagashima, F.; Matsumura, N.; Ashigaki, Y.; Asakawa, Y. J. Hattori Bot. Lab. 2003, 94, 197.

[217] Zhao, X.; Zheng, G. W.; Niu, X. M.; Li, W. Q.; Wang, F. S.; Li, S. H. J. Agric. Food Chem. 2009, 57, 478.

[218] Wallaart, T. E.; Prass, N.; Quax, W. J. J. Nat. Prod. 1999, 62, 1160.

[219] Sy, L. K.; Brown, G. D.; Haynes, R. Tetrahedron 1998, 54, 4345 .

[220] Sy, L. K.; Ngo, K. S.; Brown, G. D. Tetrahedron 1999, 55, 15127.

[221] He, L.; Hou, J.; Gan, M.; Shi, J.; Chantrapromma, Fun, S.; H. K.; Williams, I. D.; Sung, H. H. Y. J. Nat. Prod. 2008, 71, 1485 .

[222] Arciniegas, A.; Pérez-Castorena, A. L.; Reyes, S.; Contreras, J. L.; Romo de Vivar, A. J. Nat. Prod. 2003, 66, 225.

[223] Saito, Y.; Hattori, M.; Iwamoto, Y.; Takashima, Y.; Mihara, K.; Sasaki, Y.; Fujiwara, M.; Sakaoku, M.; Shimizu, A.; Chao, X.; Kuroda, C.; Gong, X.; Hanai, R.; Tori, M. Tetrahedron 2011, 67, 2220.

[224] Li, Y.; Wang, Z.; Zhang, M.; Luo, S.; Chen, J. J. Chin. Pharm. Soc. 2002, 11, 115 .

[225] Wang, C. F.; Zhao, Y.; Liu, Y. Z.; Zhang, Z. Z. Chem. Res. Chin. Univ. 2009, 25, 480.

[226] Liu, Z. L.; Liu, Q.; Tian, X. Bull. Korean Chem. Soc. 2007, 28, 292.

[227] Vuckovic, I.; Vujisic, L.; Vajs, V.; Tesevic, V.; Macura, S.; Janackovic, P.; Milosavljevic, S. Biochem. Syst. Ecol. 2006, 34, 303 .

[228] Todorova, M.; Staneva, J.; Denkova, P.; Evstatieva, L. Nat. Prod. Res. 2008, 22, 907

[229] Staneva, J. D.; Todorova, M. N.; Evstatieva, L. N. Biochem. Syst. Ecol. 2005, 33, 97.

[230] Ngo, K. S.; Brown, G. D. Phytochemistry 1999, 50, 1213.

[231] Efange, S. M. N.; Brun, R.; Wittlin, S.; Connolly, J. D.; Hoye, T. R.; McAkam, T.; Makolo, F. L.; Mbah, J. A.; Nelson, D. P.; Nyongbela, K. D.; Wirmum, C. K. J. Nat. Prod. 2009, 72, 280.

[232] Mahmoud, A. A. Planta Med. 1998, 64, 724.

[233] Ngo, K. S.; Brown, G. D. Tetrahedron 1999, 55, 759.

[234] Rustaiyan, A.; Nahrevanian, H.; Kazemi, M.; Larijani, K. Planta Med. 2007, 73, 892.

[235] Margaros, I.; Montagnon, T.; Tofi, M.; Pavlakos, E.; Vassilikogiannakis, G. Tetrahedron 2006, 62, 5308.
[236] Zhang, H. J.; Tan, G. T.; Hoang, V. D.; Hung, N. V.; Cuong, N. M.; Soejarto, D. D.; Pezzuto, J. M.; Fong, H. H. S. Tetrahedron Lett. 2001, 42, 8587.

[237] Slack, R. D.; Jacobine, A. M.; Posner, G. H. Med. Chem. Comm. 2012, 3, 281.

[238] Luo, W.; Liu, Y.; Cong, L.; Sun, L.; Guo, C. Chin. J. Med. Chem. 2012, 22, 155.

[239] Li, Y. Acta. Pharm. Sin. 2012, 33, 1141

[240] Miao, W. W.; Zhang, Y.; Zhang, A. 'Discovery of Antimalarial Drug Artemisinin and Beyond', in Case Studies in Modern Drug Discovery and Development (eds X. H. Huang and R. G. Aslanian), Wiley, New Jersey, 2012.

[241] Aboushoer, M. I.; Fathy, H. M.; Abdel-Kader, M. S.; Goetz, G.; Omar, A. A. Nat. Prod. Res. 2010, 24, 687.

[242] Yodsaoue, O.; Sonprasit, J.; Karalai, C.; Ponglimanont, C., Tewtrakul, S.; Chantrapromma, S. Phytochemistry 2012, 76, 83.

[243] Sutthivaiyakit, S.; Mongkolvisut, W.; Ponsitipiboon, P.; Prabpai, S.; Kongsaeree, P.; Ruchirawat, S.; Mahidol, C. Tetrahedron Lett. 2003, 44, 3637.

[244] Wu, C. L.; Jong, J. R. J. Asian Nat. Prod. Res. 2001, 3, 241

[245] Bomm, M. D.; Zukerman-Schpector, J.; Lopes, L. M. X. Phytochemistry 1999, 50, 455.

[246] Whitson, E. L.; Thomas, C. L.; Henrich, C. J.; Sayers, T. T.; McMahon, J. B.; McKee, T. C. J. Nat. Prod. 2010, 73, 2013.

[247] Choi, S. Z.; Kwin, H. C.; Choi, S. U.; Lee, K. R. J. Nat. Prod. 2002, 65, 1102 .

[248] Ramos, F.; Takaishi, Y.; Kashiwada, Y.; Osorio, C.; Duque, C.; Acuna, R.; Fujimoto, Y. Phytochemistry 2008, 69, 2406.

[249] Moghaddam, F. M.; Farimani, M. M.; Seirafi, M.; Taheri, S. Khavasi, H. R.; Sendker, J.; Proksch, P.; Wray, ; V.; Edrada, R. J. Nat. Prod. 2010, 73, 1601.

[250] Minami, H.; Anzaki, S.; Kubo, M.; Kodama, M.; Kawazu, K.; Fukuyama, Y. Chem. Pharm. Bull. 1998, 46, 1194.

[251] Fukuyama, Y.; Minami, H.; Matsuo, A.; Kitamura, K.; Akizuki, M.; Kubo, M. Chem. Pharm. Bull. 2002, 50, 368.

[252] Shen, Y. C.; Prakash, C. V. S.; Wang, L. T.; Chien, C. T.; Hung, M. C. J. Chin. Chem. Soc. 2003, 50, 297.

[253] Kubo, M.; Minami, H.; Hayashi, E.; Kodama, M.; Kawazu, K.; Fukuyama, Y. Tetrahedron Lett. 1999, 40, 6261.

[254] Fujioka, T.; Yamamoto, M.; Kashiwada, Y.; Fujii, H.; Mihashi, K.; Ikeshiro, Y.; Chen, I. S.; Lee, K. H. Bioorg. Med. Chem. Lett. 1998, 8, 3479.

[255] Devkota, K. P.; Lenta, B. N.; Wansi, J. D.; Sewald, N. Phytochemistry Lett. 2010, 3, 24.

[256] Qu, J. B.; Zhu, R. L.; Zhang, Y. L.; Guo, H. F.; Wang, X. N.; Xie, C. F.; Yu, W. T.; Ji, M.; Lou, H. X. J. Nat. Prod. 2008, 71 , 1418.

[257] Wang, Y. L.; Chang, F. R.; Wu, C. C.; Wang, W. Y.; Wu, Y. C. J. Nat. Prod. 2002, 65, 1462.

[258] Adelekan, A. M.; Prozesky, E. A.; Hussein, A. A.; Urena, L. D.; van Rooyen, P. H.; Liles, D. C.; Meyer, J. J. M.; Rodriguez, B. J. Nat. Prod. 2008, 71, 1919.

[259] Yin, S.; Su, Z. S.; Zhou, Z. W.; Dong, L.; Yue, J. M. J. Nat. Prod. 2008, 71, 141

[260] Corea, G.; Fattorusso, C.; Fattorusso, E.; Lanzotti, V. Tetrahedron 2005, 61, 4485.

[261] Chen, Y. L.; Lan, Y. H.; Hsieh, P. W.; Wu, C. C.; Chen, S. L.; Yen, C. T.; Chang, F. R.; Hung, W. C.; Wu, Y. C. J. Nat. Prod. 2008, 71, 1207.

[262] Barrero, A. F.; Quilez del Moral, J. F.; Herrador, M. M.; Arteaga, J. F.; Akssira, M.; Benharref, A.; Dakir, M. Phytochemistry 2005, 66, 105 .

[263] Sy, L. K.; Brown, G. D. J. Nat. Prod. 1998, 61, 907.

[264] Liu, Y. W.; Cheng, Y. B.; Liaw, C. C.; Chen, C. H.; Guh, J. H.; Hwang, T. L.; Tsai, J. S.; Wang, W. B.; Shen, Y. C. J. Nat. Prod. 2012, 75, 689 .

[265] Barrero, A. F.; del Moral, J. F. Q.; Aitigri, M. Phytochemistry 2004, 65, 2507 
[266] Guo, F.; Xi, M.; Li, Y. Tetrahedron Lett. 1999, 40, 947.

[267] Ulubelen, A.; Tan, N.; Sonmez, U.; Topcu, G. Phytochemistry 1998, 47, 899

[268] Niu, X.; Li, S.; Zhao, Q.; Sun, H.; Lu, Y. Tetrahedron Lett. 2002, 43, 5277.

[269] Wang, R.; Chen, W. H.; Shi, Y. P. J. Nat. Prod. 2010, 73, 17

[270] Chiang, Y. M.; Kuo, Y. H. J. Nat. Prod. 2000, 63, 898.

[271] Kuo, Y. H.; Chiang, Y. M. Chem. Pharm. Bull. 2000, 48, 593.

[272] Chiamg, Y. M.; Kuo, Y. H. J. Nat. Prod. 2001, 64, 436.

[273] Maeda, K.; Naitou, T.; Umishio, K.; Fukuhara, T.; Motoyama, A. Biol. Pharm. Bull. 2007, 30,873.

[274] Chen, J. J.; Fei, D. Q.; Chen, S. G.; Gao, K. J. Nat. Prod. 2008, $71,547$.

[275] Triana, J.; Lopez, M.; Perez, F. J.; Rico, M.; Lopez, A.; Estevez, F.; Marrero, M. T.; Brouard, I.; Leon, F. Molecules 2012 $17,12895$.

[276] Song, Y. L.; Zhang, L.; Gao, J. M.; Du, G. H.; Cheng, Y. X. J. Asian Nat. Prod. Res. 2008, 10, 214.

[277] Wu, Q. X.; Liu, X.; Shi, Y. P. Chem. Biodiversity 2007, 4, 175.

[278] Nguyen, H. T.; Yang, S. Y.; Kim, J. A.; Song, G. Y.; Kim, Y. H. Bull. Korean Chem. Soc. 2010, 31, 3423.

[279] Dou, D. Q.; Chen, Y. J.; Liang, L. H.; Pamg, F. G.; Shimizu, N.; Takeda, T. Chem. Pharm. Bull. 2001, 49, 442.

[280] Tung, N. H.; Song, G. Y.; Nhiem, N. X.; Ding, Y.; Tai, B. H.; Jin, L. G.; Lim, C. M.; Hyun, J. W.; Park, C. J.; Kang, H. K.; Kim, Y. H. J. Agric. Food Chem. 2010, 58, 868.

[281] Yoshikawa, M.; Sugimoto, S.; Nakamura, S.; Matsuda, H. Chem. Pharm. Bull. 2007, 55, 571.

[282] Nakamura, S.; Sugimoto, S.; Matsuda, H.; Yoshikawa, M. Heterocycles 2007, 71, 577.

[283] Tung, N. H.; Cho, K.; Kim, J. A.; Song, G. Y.; Kim, Y. H. Bull. Korean Chem. Soc. 2010, 31, 1381.

[284] Asai, T.; Hara, N.; Fujimoto, Y. Phytochemistry 2010, 71, 877.

[285] Lee, I. S.; Oh, S. R.; Ahn, K. S.; Lee, H. K. Chem. Pharm. Bull. 2001, 49, 1024

[286] Qiu, F.; Ma, Z.; Xu, S.; Yao, X.; Chen, Y.; Che, Z. Zhongguo Yaowu Huaxue Zashi 1998, 8, 285.

[287] Pakhathirathien, C.; Karalai, C.; Ponglimanont, C.; Subhadhirasakul, S.; Chantrapromma, K. J. Nat. Prod. 2005, 68, 1787.

[288] Zhang, F.; Wang, J. S.; Gu, Y. C.; Kong, L. Y. J. Nat. Prod. 2010, 73, 2042 .

[289] Xu, X. H.; Yang, N. Y.; Qian, S. H.; Xie, N.; Duan, J. A. J. Asian Nat. Prod. Res. 2008, 10, 33.

[290] Akihisa, T.; Nakamura, Y.; Tokuda, H.; Uchiyama, E.; Suzuki, T.; Kimura, Y.; Uchikura, K.; Nishino, H. J. Nat. Prod. 2007, 70,948 .

[291] Nakamura, S.; Iwami, J.; Matsuda, H.; Mizuno,S.; Yoshikawa, M. Tetrahedron 2009, 65, 2443.

[292] AbdelBar, F. M.; Zaghloul, A. M.; Bachawal, S. V.; Sylvester, P. W.; Ahmad, K. F.; El Sayed, K. A. J. Nat. Prod. 2008, 71, 1787.

[293] Lee, D.; Cuendet, M.; Axelrod, F.; Chavez, P. I.; Fong, H. H. S.; Pezzuto, J. M.; Kinghorn, A. D. Tetrahedron 2001, 57, 7107.

[294] Lacroix, D.; Prado, S.; Deville, A.; Krief, S.; Dumontet, V.; Kasenene, J.; Mouray, E.; Bories, C.; Bodo, B. Phytochemistry 2009, 70, 1239

[295] Banskota, A. H.; Tezuka, Y.; Phung, L. K.; Tran, K. Q.; Saiki, I.; Miwa, Y.; Taga, T.; Kadota, S. Bioorg. Med. Chem. Lett. 1998, 8, 3519.

[296] Bankota, A. H.; Tezuka, Y.; Tran, K. Q.; Tanaka, K.; Saiki, I.; Kadota, S. J. Nat. Prod. 2000, 63, 57.

[297] He, A.; Whang, M.; Hao, H.; Zhang, D.; Lee, K. H. Phytochemistry 1998, 49, 2607.

[298] Vazdekis, N. E. J.; Chavez, H.; Estevez-Braun, A.; Ravelo, A. G. J. Nat. Prod. 2009, 72, 1045.

[299] Ding, Y.; Liang, C.; Kim, J. H.; Lee, Y. M.; Hyun, J. H.; Kang, H. K.; Kim, J. A.; Min, B. S.; Kim, Y. H. Bioorg. Med. Chem. Lett. 2010, 20, 1528.
[300] Ma, Y. P.; Li, N.; Gao, J.; Fu, K. L.; Qin, Y.; Li, G. Y.; Wang, J. H. Helv. Chim. Acta. 2011, 94, 1881.

[301] Chen, J. X.; Chen, J. C.; Sun, Y.; Yan, Y. X.; Kong, L. M.; Li, Y.; Qiu, M. H. Planta Med. 2011, 77, 1844.

[302] Itokawa, H.; Kishi, E.; Morita, H.; Takeya, K.; Iitaka, Y. Chem. Lett. 1991, 12, 2221.

[303] Morimoto, Y.; Iwai, T.; Kinoshita, T. Tetrahedron Lett. 2001 , $42,6307$.

[304] Zhang, Y.; Tang, C. P.; Ke, C. Q.; Yao, S.; Ye, Y. J. Nat. Prod. 2010, 73, 664

[305] Wu, S. B.; Su, J. J.; Sun, L. H.; Wang, W. X.; Zhao, Y.; Li, H.; Zhang, S. P.; Dai, G. H.; Wang, C. G.; Hu, J. F. J. Nat. Prod. 2010, 73, 1898

[306] Pettit, G. R.; Numata, A.; Iwamoto, C.; Morito, H.; Yamada, T.; Goswami, A.; Clewlow, P. J.; Cragg, G. M.; Schmidt, J. M. J. Nat. Prod. 2002, 65, 1886.

[307] Tan, Q. G.; Li, X. N.; Chen, H.; Feng, T.; Cai, X. H.; Luo, X. D. J. Nat. Prod. 2010, 73, 693.

[308] Xu, W.; Zhu, C.; Cheng, W.; Fan, X.; Chen, X.; Yang, S.; Guo, Y.; Ye, F.; Shi, J. J. Nat. Prod. 2009, 72, 1620.

[309] Tan, J. M.; Qiu, Y. H.; Tan, X. Q.; Tan, C. H. Helv. Chim. Acta. 2011, 94, 1697.

[310] Zhou, T.; Zhang, H.; Zhu, N.; Chiu, P. Tetrahedron 2004, 60, 4931.

[311] Yang, J. H.; Pu, J. X.; Wen, J.; Li, X. N.; He, F.; Xue, Y. B.; Wang, Y. Y.; Li, Y.; Xiao, W. L.; Sun, H. D. J. Nat. Prod. 2010, 73, 12 .

[312] He, F.; Pu, J. X.; Huang, S. X.; Wang, Y. Y.; Xiao, W. L.; Li, L. M.; Liu, J. P.; Zhang, H. B.; Li, Y.; Sun, H. D. Org. Lett. 2010, $12,1208$.

[313] Ali, Z.; Khan, S. I.; Fronczek, F. R.; Khan, I. A. Phytochemistry 2007, 68, 373

[314] Ali, Z.; Khan, I. A.; Fronczek, F. R. Acta Crystallogr., Sect. E 2007, 63, o2101.

[315] Schlegel, B.; Härtl, A.; Dahse, H. M.; Gollmick, F. A.; Gräfe, U.; Dörfelt, H.; Kappes, B. J. Antibiot. 2002, 55, 814

[316] Rychnovsky, S. D. Org. Lett. 2006, 8, 2895.

[317] Porco Jr., J. A.; Su, S.; Lei, X. G.; Bardhan, S.; Rychnovsky, S. D. Angew. Chem. Int. Ed. 2006, 118, 5922.

[318] Henry, G. E.; Jacobs, H.; Carrington, C. M. S.; McLean, S.; Reynolds, W. F. Tetrahedron 1999, 55, 1581.

[319] Christian, O. E.; Henry, G. E.; Jacobs, H.; McLean, S.; Reynolds, W. F. J. Nat. Prod. 2001, 64, 23.

[320] Xiao, Z. Y.; Zeng, Y. H.; Mu, Q.; Shiu, W. K. P.; Gibbons, S Chem. Biodiversity 2010, 7, 953.

[321] Devkota, K. P.; Wilson, J.; Henrich, C. J.; McMahon, J. B.; Reilly, K. M.; Beutler, J. A. J. Nat. Prod. 2013, 76, 59.

[322] Shiu, W. K. P.; Rahman, M. M.; Curry, J.; Stapleton, P.; Zloh, M.; Malkinson, J. P.; Gibbons, S. J. Nat. Prod. 2012, 75, 336.

[323] Sripisut, T.; Ritthiwigrom, T.; Promgool, T.; Yossathera, K.; Deachathai, S.; Phakhodee, W.; Cheenpracha, S.; Laphookhieo, S. Phytochemistry Lett. 2012, 5, 379.

[324] Yin, S.; Wang, X. N.; Fan, C. Q.; Liao, S. G.; Yue, J. M. Org. Lett. 2007, 9, 2353

[325] Ferreira, I. C. P.; Cortez, D. A. G.; da Silva, M. F. D.; Fo, E. R.; Vieira, P. C.; Fernandes, J. B. J. Nat. Prod. 2005, 68, 413

[326] Cui, J. X.; Wu, J.; Deng, Z. W.; Proksch, P.; Lin, W. H. J. Nat. Prod. 2007, 70, 772

[327] Ge, Y. H.; Zhang, J. X.; Mu, S. Z.; Chen, Y.; Yang, F. M.; Lu Y.; Hao, X. J. Tetrahedron 2012, 68, 566

[328] Liu, L.; Niu, S. B.; Lu, X. H.; Chen, X. L.; Zhang, H.; Guo, L. D.; Che, Y. S. Chem. Commun. 2010, 46, 460.

[329] Hakim, E. H.; Fahriyati, A.; Kau, M. S.; Achmad, S. A.; Makmur, L.; Ghisalberti, E. L.; Nomura, T. J. Nat. Prod. 1999 $62,613$.

[330] Queiroz, E. F.; Hay, A. E.; Chaaib, F.; van Diemen, D.; Diallo, D.; Hostettmann, K. Planta Med. 2006, 72, 746.

[331] Fatima, I.; Ahmad, I.; Anis, I.; Malik, A.; Afza, N.; Iqbal, L.; Latif, M. Arch. Pharm. Res. 2008, 31, 999. 
[332] Cirigliano, A. M.; Veleiro, A. S.; Oberti, J. C.; Burton, G. J. Nat. Prod. 2002, 65, 1049.

[333] Ito, C.; Itoigawa, M.; Kojima, N.; Tokuda, H.; Hirata, T.; Nishino, H.; Furukawa, H. J. Nat. Prod. 2004, 67, 1125.

[334] Ito, C.; Itoigawa, M.; Mishina, Y.; Cechinel, V.; Mukainaka, T.; Tokuda, H.; Nishino, H.; Furukawa, H. J. Nat. Prod. 2002, 65, 267

[335] Li, X. N.; Pu, J. X.; Du, X.; Yang, L. M.; An, H. M.; Lei, C.; Luo, F. X.; Zheng, Y. T.; Lu, Y.; Xiao, W. L.; Sun, H. D. J. Nat. Prod. 2009, 72, 1131.

[336] Chavasiri, W. Tetrahedron Lett. 2003, 44, 6759.

[337] Yin, S.; Chen, X.; Su, Z. S.; Yang, S. P.; Fan, C. Q.; Ding, J.; Yue, J. M. Tetrahedron 2009, 65, 1147.

[338] Chang, S. Y.; Cheng, M. J.; Kuo, Y. H.; Lee, S. J.; Chang, H. S.; Chen, I. S. Helv. Chim. Acta 2008, 91, 1156.

[339] Lee, S. S.; Lin, Y. S.; Chen, C. K. J. Nat. Prod. 2009, 72, 1249.

[340] Williams, R. B.; Martin, S. M.; Hu, J. F.; Norman,V. L.; Goering, M. G.; Loss, S.; O'Neil-Johnson, M.; Eldridge, G. R.; Starks, C. M. J. Nat. Prod. 2012, 75, 1319.

[341] Perez-Gutierrez, S.; Sanchez-Mendoza, E.; Martinez-Gonzalez, D.; Zavala-Sanchez, M. A.; Perez-Gonzalez, C. Molecules 2012, 17, 2049.

[342] Baba, K.; Nakata, K.; Tanifuchi, M.; Kido, T.; Kozawa, M. Phytochemistry 1990, 29, 3907.

[343] Sugii, M.; Ohkita, M.; Taniguchi, M.; Baba, K.; Kawai, Y.; Tahara, C.; Takaoka, M.; Matsumura, Y. Biol. Pharm. Bull. 2005, 28, 607.

[344] Nakashima, K.; Oyama, M.; Ito, T.; Murata, H.; Iinuma, M. Heterocycles 2011, 83, 1603.

[345] Lee, T. H.; Lu, C. K.; Kuo, Y. H.; Lo, J. M.; Lee, C. K. Helv. Chim. Acta. 2008, 91, 79

[346] de Mesquita, M. L.; Araujo, R. M.; Bezerra, D. P.; Braz, R.; de Paula, J. E.; Silveira, E. R.; Pessoa, C.; de Moraes, M. O.; Lotufo, L. V. C.; Espindola, L. S. Bioorg. Med. Chem. 2011, 19, 623.

[347] Takahashi, S.; Nakano, T.; Koiwa, T.; Noshita, T.; Funayama, S.; Koshino, H.; Nakagawa, A. J. Antibiot. 2000, 53, 163.

[348] Yang, H.; Hou, A. J.; Mei, S. X.; Sun, H. D.; Che, C. T. J. Asian Nat. Prod. Res. 2002, 4, 165.

[349] Ito, C.; Katsuno, S.; Itoigawa, M.; Ruangrungsi, N.; Mukainaka, T.; Okuda, M.; Kitagawa, Y.; Tokuda, H.; Nishino, H.; Furukawa, H. J. Nat. Prod. 2000, 63, 125.

[350] Lago, J. H. G.; Chen, A.; Young, M. C. M.; Guimaraes, E. F.; de Oliveira, A.; Kato, M. J. Phytochemistry Lett. 2009, 2, 96.

[351] Danelutte, A. P.; Lago, J. H. G.; Young, M. C. M.; Kato, M. J. Phytochemistry 2003, 64, 555.

[352] Yu, D. Q.; Chen, R. Y.; Huang, L. J.; Xie, F. Z.; Ming, D. S.; Zhou, K.; Li, H. Y.; Tong, K. M. J. Asian Nat. Prod. Res. 2008, 10,851 .

[353] Li, L. B.; Ren, J.; Lai. R.; Cheng, Z. M.; Zhu, H. J. Gaodeng Xuexiao Huaxue Xuebao 2011, 32, 891.

[354] Cheng, Y. X.; Zhou, J.; Tan, N. H.; Lu, T.; Liu, X. Y.; Zheng, Q. T. Heterocycles 2001, 55, 1943.

[355] Oh, D. C.; Scott, J. J.; Currie, C. R.; Clardy, J. Org. Lett. 2009, 11,633 .

[356] Vouffo, B.; Dongo, E.; Facey, P.; Thom, A.; Sheldrick, G.; Maier, A.; Fiebig, H. H.; Laatsch, H. Planta Med. 2010, 76, 1717.

[357] Wieland, P.; Prelog, V. Helv. Chim. Acta 1947, 30, 1028.

[358] Kuo, Y. C.; Wenig, S. C.; Chou, C. J.; Chang, T. T.; Tsai, W. J. Br. J. Pharmacol. 2003, 140, 895.

[359] Im, K. S.; Nam, K. I.; Sim, C. J.; Jung, J. H. Saengyak Hakhoechi 2000, 31, 401 .

[360] Nam, K. S.; Jo, Y. S.; Kim, Y. H.; Hyun, J. W.; Kim, H. W. Life Sci. 2001, 69, 229.

[361] Yokoyama, S.; Bang, T. H.; Shimizu, K.; Kondo, R. Nat. Prod. Commun. 2012, 7, 1163.

[362] Ramos-Ligonio, A.; Lopez-Monteon, A.; Trigos, A. Phytotherapy Res. 2012, 26, 938.
[363] Macias, F. A.; Chinchilla, N.; Varela, R. M.; Molinillo, J. M. Steroids 2006, 71, 603.

[364] Kuo, L. M. Y.; Chen, K. Y.; Hwang, S. Y.; Chen, J. L.; Liu, Y. Y.; Liaw, C. C.; Ye, P. H.; Chou, C. J.; Shen, C. C.; Kuo, Y. H. Planta Med. 2005, 71, 77.

[365] Lee, S. H.; Shim, S. H.; Kim, J. S.; Kang, S. S. Arch. Pharm. Res. 2006, 29, 479.

[366] Takei, T.; Yoshida, M.; Ohnishi-Kameyama, M.; Kobori, M. Biosci. Biotechnol. Biochem. 2005, 69, 212.

[367] Tewtrakul, S.; Tansakul, P.; Daengrot, C.; Ponglimanont, C.; Karalai, C. Phytomedicine 2010, 17, 851.

[368] Zheng, M. S.; Hwang, N. K.; Kim, D. H.; Moon, T. C.; Son, J. K.; Chang, H. W. Arch. Pharmacal Res. 2008, 31, 318.

[369] Kobori, M.; Yoshida, M.; Ohnishi-Kameyama, M.; Shinmoto, H. Br. J. Pharmacol. 2007, 150, 209.

[370] Seo, H. W.; Hung, T. M.; Na, M.; Jung, H. J.; Kim, J. C.; Choi, J. S.; Kim, J. H.; Lee, H. K.; Lee, I.; Bae, K.; Hattori, M.; Min, B. S. Arch. Pharm. Res. 2009, 32, 1573.

[371] Duarte, N.; Ferreira, M. J. U.; Martins, M.; Viveiros, M.; Amaral, L. Phytotherapy Res. 2007, 21, 601.

[372] You, F.; Han, T.; Wu, J. Z.; Huang, B. K.; Qin, L. P. Biochem. Syst. Ecol. 2009, 37, 162

[373] Truong, N. B.; Pham, C. V.; Doan, H. T. M.; Nguyen, H. V.; Nguyen, C. M.; Nguyen, H. T.; Zhang, H. J.; Fong, H. H. S.; Franzblau, S. G.; Soejarto, D. D.; Chaet, M. H. J. Nat. Prod. 2011, 74, 1318.

[374] Xu, G. H.; Choo, S. J.; Kim, Y. H.; Ryoo, I. J.; Seok, S. J.; Ahn, J. S.; Yoo, I. D. J. Microbiol. Biotechnol. 2010, 20, 78.

[375] Toume, K.; Ishibashi, M. Phytochemistry 2002, 61, 359.

[376] Wu, X.; Wang, L.; Wang, G. C.; Wang, H.; Dai, Y.; Ye, W. C.; Li, Y. L. Planta Med. 2012, 78, 1667.

[377] Sera, Y.; Adachi, K.; Shizuri, Y. J. Nat. Prod. 1999, 62, 152.

[378] Sheu, J. H.; Chang, K. C.; Duh, C. Y. J. Nat. Prod. 2000, 63, 149.

[379] Yu, S.; Deng, Z.; van Ofwegen, L.; Proksch, P.; Lin, W. Steroids 2006, 71, 955.

[380] Luo, X.; Li, F. M.; Shinde, P. B.; Hong, J. K.; Lee, C. O.; Im, K. S.; Jung, J. H. J. Nat. Prod. 2006, 69, 1760.

[381] Gauvin, A.; Smadja, J.; Aknin, M.; Faure, R.; Gaydou, E. M. Canadian J. Chem. 2000, 78, 986.

[382] Ioannou, E.; Abdel-Razik, A. F.; Zervou, M.; Christofidis, D.; Alexi, X.; Vagias, C.; Alexis, M. N.; Roussis, V. Steroids 2009 $74,73$.

[383] Li, X. D.; Miao, F. P.; Ji, N. Y. Molecules 2011, 16, 8646

[384] Yaoita, Y.; Amemiya, K.; Ohnuma, H.; Furumura, K.; Masaki, A.; Matsuki, T.; Kikuchi, M. Chem. Pharm. Bull. 1998, 46, 944.

[385] Yuan, L.; Ma, J.; Wang, T.; Li, G. H.; Shen, Y. M.; Zhao, P. J. Chem. J. Chin. Univ. 2009, 30, 78.

[386] Iwashima, M.; Terada, I.; Iguchi, K.; Yamori, T. Chem. Pharm. Bull. 2002, 50, 1286.

[387] Wang, F.; Fang, Y.; Zhang, M.; Lin, A.; Zhu, T.; Gu Q.; Zhu, W. Steroids 2008, 73, 19

[388] Yaoita, Y.; Yoshihara, Y.; Kakuda, R.; Machida, K.; Kikuchi, M. Chem. Pharm. Bull. 2002, 50, 551.

[389] Wu, J.; Choi, J. H.; Yoshida, M.; Hirai, H.; Harada, E.; Masuda, K.; Koyama, T.; Yazawa, K. Noguchi, K.; Nagasawa, K.; Kawagishi, H. Tetrahedron 2011, 67, 6576.

[390] Yaoita, Y.; Matsuki, K.; Iijima, T.; Nakano, S.; Kakuda, R.; Machida, K.; Kikuchi, M. Chem. Pharm. Bull. 2001, 49, 589.

[391] Sung, P. J.; Lin, M. R.; Chen, J. J.; Lin, S. F.; Wu, Y. C.; Hwang, T. L.; Fang, L. S. Chem. Pharm. Bull. 2007, 55, 666.

[392] Sheu, J. H.; Wang, G. H.; Sung, P. J.; Duh, C. Y. J. Nat. Prod. 1999, 62, 224

[393] Sheu, J. H.; Chang, K. C.; Sung, P. J.; Duh, C. Y.; Shen, Y. C. J. Chin. Chem. Soc. 1999, 46, 253.

[394] Wu, S. B.; Bao, Q. Y.; Wang, W. X.; Zhao, Y.; Xia, G.; Zhao, Z.; Zeng, H. Q.; Hu, J. F. Planta Med. 2011, 77, 922.

[395] Fang, H. Y.; Liaw, C. C.; Chao, C. H.; Wen, Z. H.; Wu, Y. C.; 
Hsu, C. H.; Dai, C. F.; Sheu, J. H. Tetrahedron, 2012, 68, 9694. [396] Wang, P.; Qin, H. L.; Zhang, L.; Li, Z. H.; Wang, Y. H.; Zhu, H. B. Planta Med. 2004, 70, 1075.

[397] Feng, J. Q.; Zhang, R. J.; Zhou, Y.; Chen, Z. H.; Tang, W.; Liu, Q. F.; Zuo, J. P.; Zhao, W. M. Phytochemistry 2008, 69, 2716.

[398] Itokawa, H.; Xu, J. P.; Takeya, K.; Watanabe, K.; Shoji, J. Chem. Pharm. Bull. 1988, 36, 982.

[399] Itokawa, H.; Xu, J. P.; Takeya, K.; Watanabe, K. Chem. Pharm. Bull. 1988, 36, 2084.

[400] Wang, L. Y.; Chen, Z. H.; Zhou, Y.; Tang, W.; Zuo, J. P.; Zhao, W. M. Phytochemistry 2011, 72, 2230.
[401] Feussner, I.; Wasternack, C. Annu. Rev. Plant Biol. 2002, 53, 275.

[402] Noordermeer, M. A.; Veldink, G. A.; Vliegenthart, J. F. Chem.Bio.Chem. 2001, 2, 494.

[403] Pohnert, G.; Boland, W. Nat. Prod. Rep. 2002, 19, 108.

[404] Barofsky, A.; Pohnert, G. Org. Lett. 2007, 9, 1017.

[405] Wichard, T.; Göbel, C.; Feussner, I.; Pohnert, G. Angew. Chem. Int. Ed. 2005, 44, 15

[406] Andreou, A.; Brodhun, F.; Feussner, I. Prog. Lipid Res. 2009, $48,148$. 